\title{
Archeological Testing of the Pavo Real Site (41BX52), San Antonio, Bexar County, Texas
}

Antonia L. Figueroa

Center for Archeological Research, University of Texas at San Antonio

Charles D. Frederick

Follow this and additional works at: https://scholarworks.sfasu.edu/ita

Part of the American Material Culture Commons, Archaeological Anthropology Commons, Environmental Studies Commons, Other American Studies Commons, Other Arts and Humanities Commons, Other History of Art, Architecture, and Archaeology Commons, and the United States History Commons

Tell us how this article helped you.

This Article is brought to you for free and open access by the Center for Regional Heritage Research at SFA ScholarWorks. It has been accepted for inclusion in Index of Texas Archaeology: Open Access Gray Literature from the Lone Star State by an authorized editor of SFA ScholarWorks. For more information, please contact cdsscholarworks@sfasu.edu. 


\section{Archeological Testing of the Pavo Real Site (41BX52), San Antonio, Bexar County, Texas}

\section{Licensing Statement}

This is a work produced for the Texas Department of Transportation (TxDOT) by the report producer. TxDOT and the report producer jointly own all rights, title, and interest in and to all intellectual property developed under TXDOT's contract with the report producer. The report may be cited and brief passages from this publication may be reproduced without permission provided that credit is given to both TXDOT and the report producer. Permission to reprint an entire chapter, section, figures or tables must be obtained in advance from either the Supervisor of the Archeological Studies Branch, Environmental Affairs Division, Texas Department of Transportation, 125 East 11th Street, Austin, Texas, 78701 or from the report producer. 


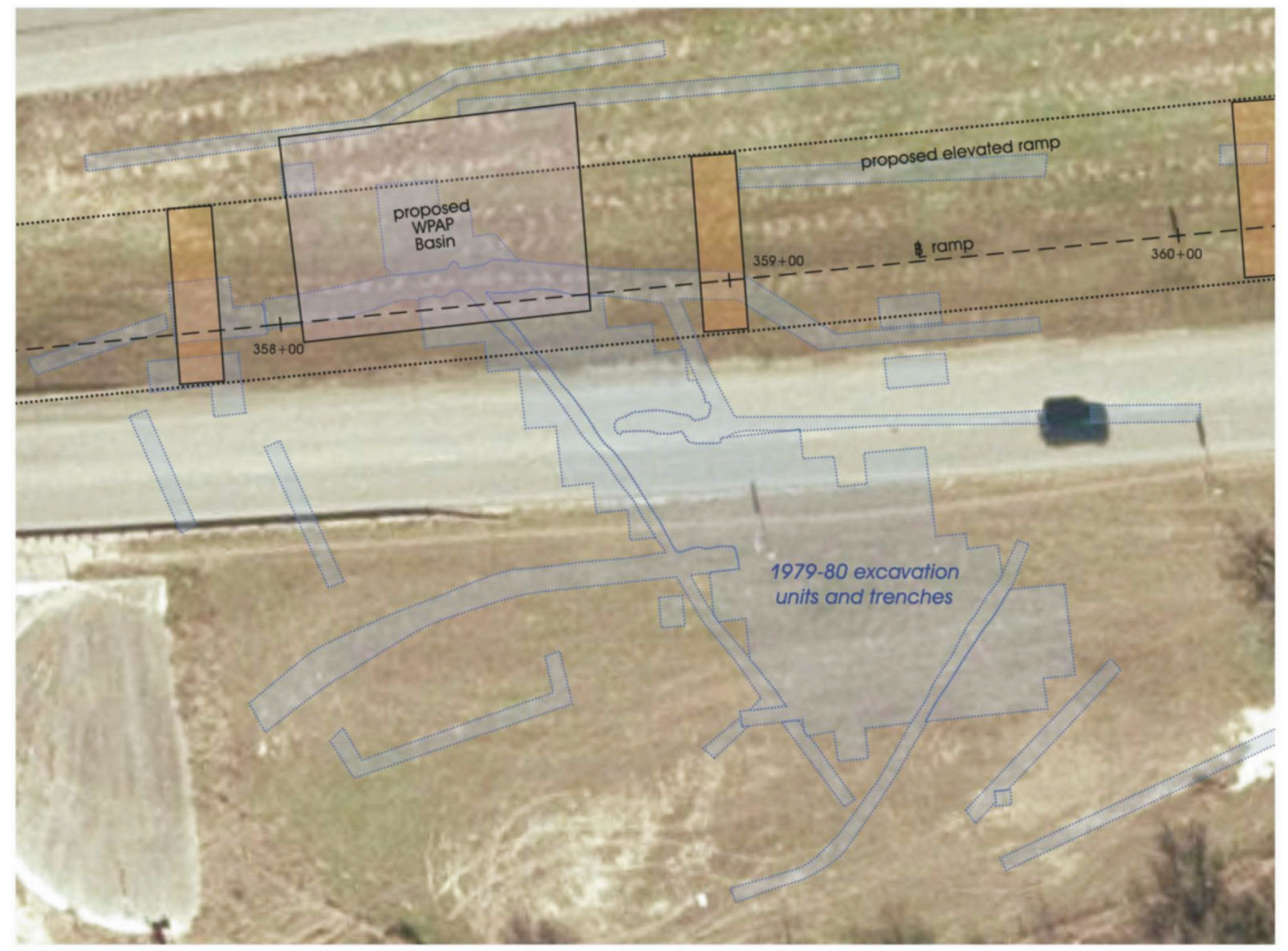

\section{Archeological Testing of the Pavo Real Site (41BX52), San Antonio, Bexar County, Texas}

by

Antonia L. Figueroa and Charles D. Frederick

Texas Antiquities Permit No. 4092

Prepared for:

HNTB Corporation

85 N.E. Loop 410 Ste. 304

San Antonio, Texas 78216
Prepared by:

Center for Archaeological Research The University of Texas at San Antonio Archaeological Report, No. 382

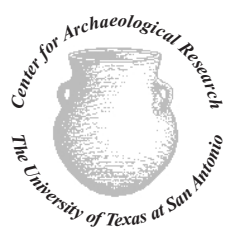




\title{
Archeological Testing of the Pavo Real Site (41BX52), San Antonio, Bexar County, Texas
}

\author{
by
}

\author{
Antonia L. Figueroa and Charles D. Frederick
}

Texas Antiquities Committee Permit No. 4092

CSJ:245203040

Principal Investigators

Steve A. Tomka and Raymond P. Mauldin

Prepared for:

HNTB Corporation

85 N.E. Loop 410 Ste. 304

San Antonio, Texas 78216

For use by:

Environmental Affairs Division

Texas Department of Transportation

Austin, Texas
Prepared by:

Center for Archaeological Research The University of Texas at San Antonio Archaeological Report, No. 382

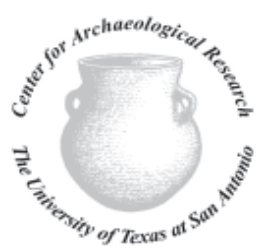





\begin{abstract}
:
The Center for Archaeological Research (CAR) at the University of Texas at San Antonio performed archeological testing at the Pavo Real site (41BX52) between November 2006 and June 2007 for HNTB. The purpose of archeological testing was to determine the depth of construction fill and the presence, location and, if possible, condition, of any remnant archeological deposits. Proposed improvements along Loop 1604 include bridge bents that will be constructed east of Leon Creek and west of the IH-10/Loop 1604 interchange overpass. Impacts associated with proposed improvements will occur within the boundaries and in the immediate vicinity of 41BX52. Archeological testing consisted of coring, backhoe trenching and block excavations. Coring and backhoe trenching within the northern and southern medians indicated the presence of thick fill material of unknown depths in the western portion of the site and a decrease in fill and soils on the eastern segment. Suite II soils, that were assumed to be associated with the first occupation of the site, were identified during backhoe trenching, initiating block excavations. Block excavations were conducted within the area to be directly impacted by a bridge bent and basin in aims of dating Suite II soils. The excavation of two 2-x-2-meter (m) blocks and two additional 1-x-1-m units produced Early Archaic diagnostics. Paleoindian period materials were not encountered during archeological investigations of the site.

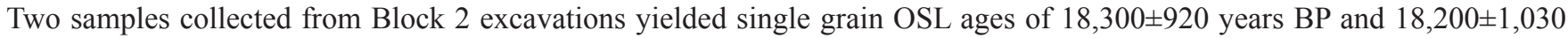
years BP. Statistical analysis concluded that lithic debitage recovered from the Suite II deposits were significantly smaller than Suites III and IV specimens, supporting the conclusion that cultural material from Suite III could have worked their way down into the deposit accounting for the specimens present in Suite II. Moreover, OSL results suggested that Suite II deposits may have undergone post-depositional disturbance.
\end{abstract}

Archeological testing of the site was conducted under Texas Antiquities permit No. 4092. The initial coring and trenching of the site was conducted under a TXDOT General Services Contract with Raymond P. Mauldin serving as the principal investigator. The subsequent testing was performed under a contract with HNTB with Steve Tomka serving as the principal investigator. Antonia L. Figueroa served as the project archeologist. Charles D. Frederick served as the project geoarcheologist. All artifacts and records collected during this project are curated at the Center for Archaeological Research according to Texas Historical Commission guidelines. 


\section{Table of Contents:}

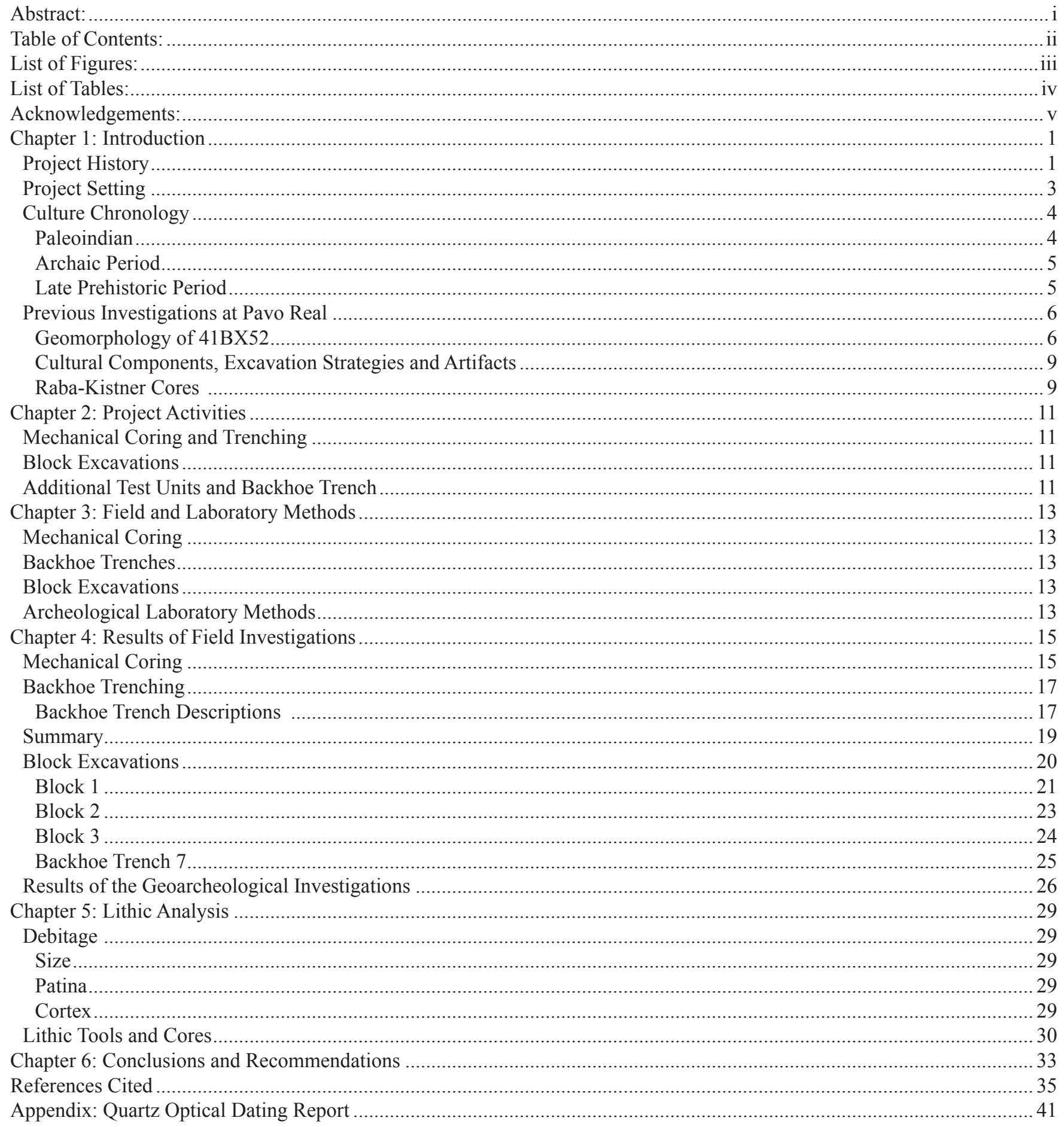




\section{List of Figures:}

Figure 1-1. Location of the project area on the Castle Hills 7.5 Minute Series USGS Quadrangle map.................................. 1

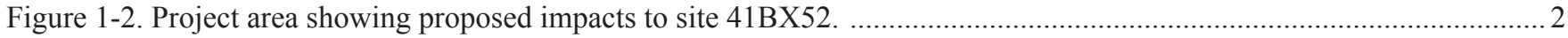

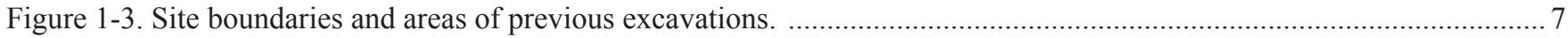

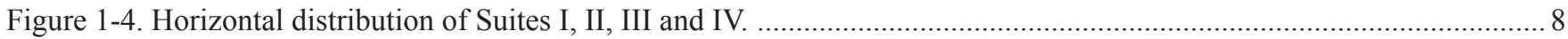

Figure 4-1. Aerial photograph of the project area showing the location of CAR's coring and backhoe trenches..................... 15

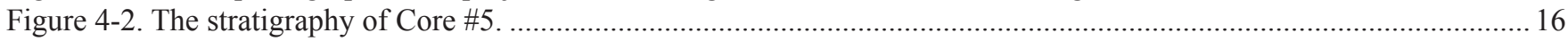

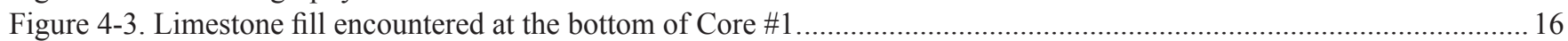

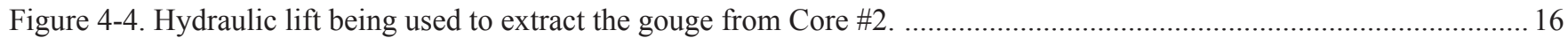

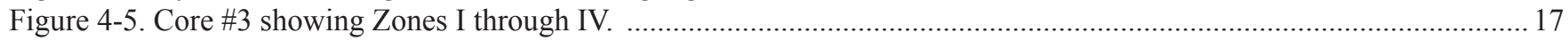

Figure 4-6. Profile of the north wall of Backhoe Trench 1 with Zones II, III and IV representing Suite II. ........................... 18

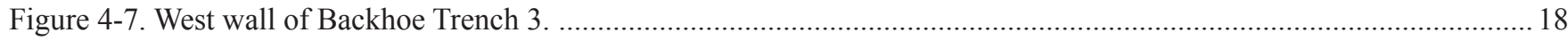

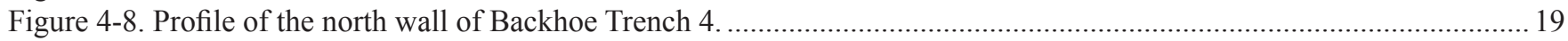

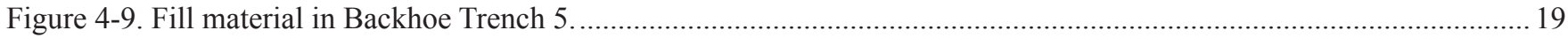

Figure 4-10. Profile of Trenches 1, 4W, 4E (from 1979-1980 project). .........................................................................2 20

Figure 4-11. Location of proposed bridge bents and basin that will impact the southern portion of the project area.. ............20

Figure 4-12. Proposed bridge bents, WPAP basin and area where mechanical stripping and block

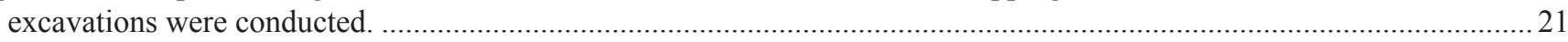

Figure 4-13. Mechanically stripped area with block excavations and Backhoe Trench 7 .................................................22

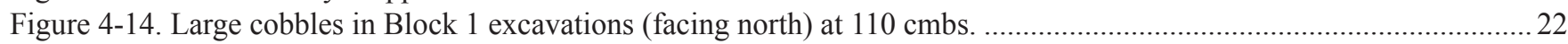

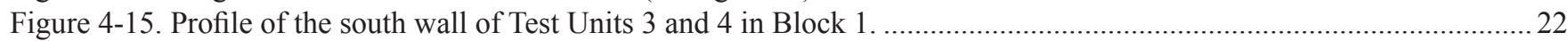

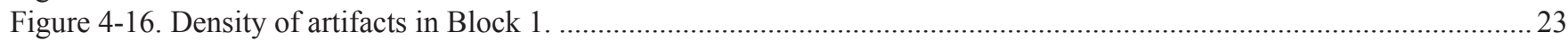

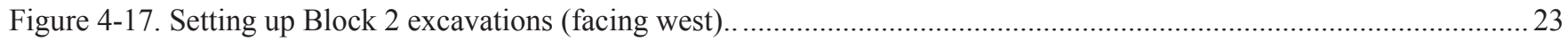

Figure 4-18. Profile of the south wall of Test Units 7, 8, 9, and 10 in Block 2.and Cores Recovered from Block 2................24

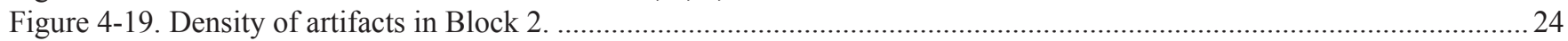

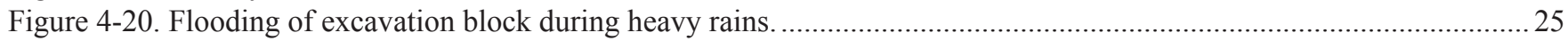

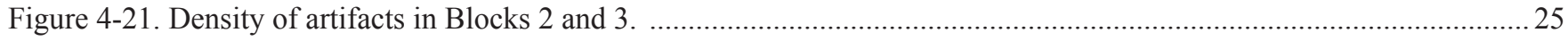

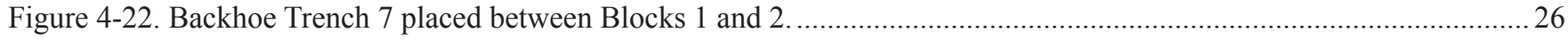

Figure 4-23. Profile showing the south wall of Backhoe Trench 7 in relation to the excavated blocks .................................26

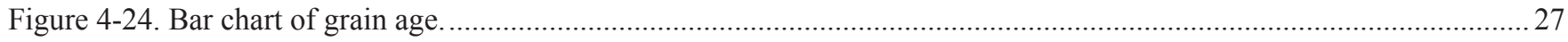

Figure 5-1. Error bar graph depicting the average maximum dimension ( $95 \%$ confidence level) of debitage by suites. .........29

Figure 5-2. Box plot showing the average maximum dimension of debitage and cortex percentage......................................30

Figure 5-3. Lithic tools from 41BX52 block excavations a) Angostura b,c) Early Split Stemmed, d) Perdiz,

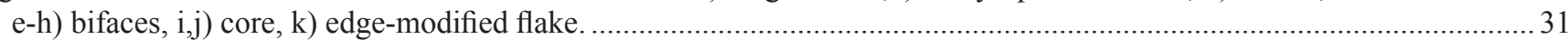




\section{List of Tables:}

Table 4-1. Burned Rock, Debitage, Lithic Tools and Cores Recovered from Block 1 .....................................................22

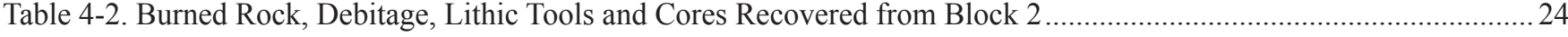

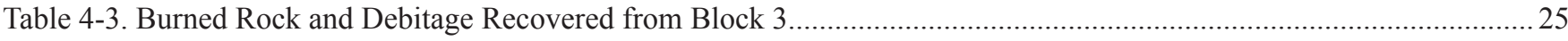

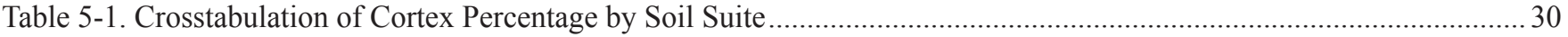




\section{Acknowledgements:}

This project involved several individuals that the authors would like to thank. The field personnel included Nate Devito, Cyndi Dickey, Jon Dowling, Steve Dunn, Leonard Kemp, Lindy Martinez, Jason Perez, Bryant Saner, and Joseph Thompson. Interns from CAR that aided in field work were Sarah Osborn and Laura Schiotis. Many thanks to Jennifer L. Thompson for supervising field operations one morning. CAR volunteers Emmett Foulds and Ross Rutherford helped with screening on many occasions. Thanks to Mike Lothain and Carl "Gator" Krueger of CESA Contractors, Inc. Dale Hudler and Dr. Michael B. Collins aided tremendously with details about the original excavations performed at the Pavo Real site. Carolyn Spock of TARL was very helpful in allowing CAR personnel to review the original maps and obtain copies. Principal Investigators Steve Tomka and Raymond Mauldin aided throughout fieldwork and provided comments on the report. Steve Tomka coordinated communication between CAR, TxDOT, and THC and provided essential comments in the drafting of the report. Al McGraw served as the primary liaison from TxDOT-ENV. Randall Grones and Erick Wildestorm from TxDOT District office in San Antonio helped coordinate safety precautions related to traffic and provided specific construction plans integral to the assessment of the site. All lab processing and curation was done under the supervision of Marybeth Tomka. Bruce Moses served as the site surveyor and, with the assistance of Leonard Kemp, created the figures in this publication. Bruce Moses also served as technical editor for the final edition of the report. 



\section{Chapter 1: Introduction}

The Center for Archaeological Research (CAR) at the University of Texas at San Antonio (UTSA) performed archeological investigations at the Pavo Real site (41BX52) between November 2006 and June 2007. A combination of coring, trenching and test unit excavations was performed on the site to determine the depth of construction fill and the presence, location and, if possible, condition, of any remnant archeological deposits. Archeological testing of the site was conducted under Texas Antiquities Permit No. 4092. The coring and testing phase was conducted under TxDOT work authorization WA 57515SA005 with Raymond Mauldin serving as principal investigator. The remainder of testing at the site occurred under a contract with HNTB with Steve Tomka serving as Principal Investigator. Antonia L. Figueroa served as the project archeologist. Charles D. Frederick served as the project geoarcheologist. areas for archeological sites that fall within the Loop 1604 road improvements corridor. That corridor runs from the intersection with Kyle Seale to the intersection with $\mathrm{IH}$ 35 North in northwest Bexar County. 41BX52 fell within the boundaries of these improvements and as a result, archeological investigations were initiated.

41BX52 is located off Loop 1604, just west of the IH-10/ Loop 1604 interchange in northwest Bexar County (Figure 1-1). The project area is bound to the west by Leon Creek. The Area of Potential Effect (APE) is in the two medians between the west and east bound main lanes of Loop 1604 and their access roads (Figure 1-2). Proposed improvements along Loop 1604 will include bridge bents that will be constructed east of Leon Creek and west of the IH-10/Loop 1604 interchange overpass. Twenty three bridge bents are proposed. Bridge bents are anticipated to penetrate to $9.5 \mathrm{~m}$

This document presents the archeological work conducted by the CAR at 41BX52. Archeological testing of the site revealed an Early Archaic component. Moreover, archeological testing clarified the geological suites defined by Collins et al. (2003). The remaining portion of this chapter discusses the project history, project area environs and the previous excavations that were conducted at 41BX52. The three phases of work performed at the site by the CAR are presented in Chapter 2. The methods employed in the field and in the laboratory are outlined in Chapter 3. The results of the archeological testing are discussed in Chapter 4. The results of the lithic debitage and tools analyses are presented in Chapter 5 . Chapter 6 provides a summary and recommendations for 41BX52.

\section{Project History}

In March 2006, The Center for Archaeological Research at the University of Texas at San Antonio (CAR-UTSA) was contracted by the HNTB Corporation to conduct an impact evaluation and intensive pedestrian survey of high probability

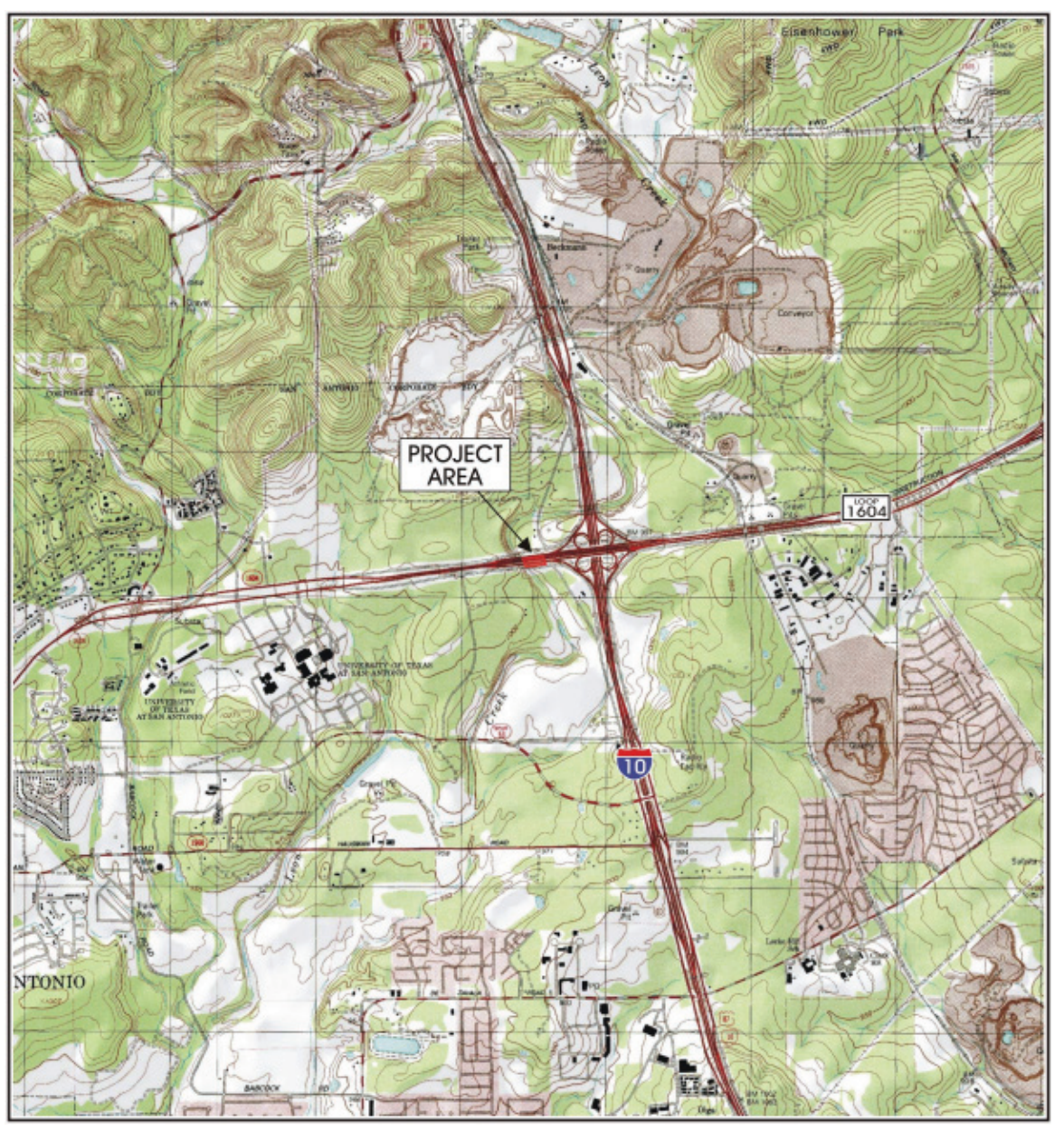

Figure 1-1. Location of the project area on the Castle Hills 7.5 Minute Series USGS Quadrangle map. 


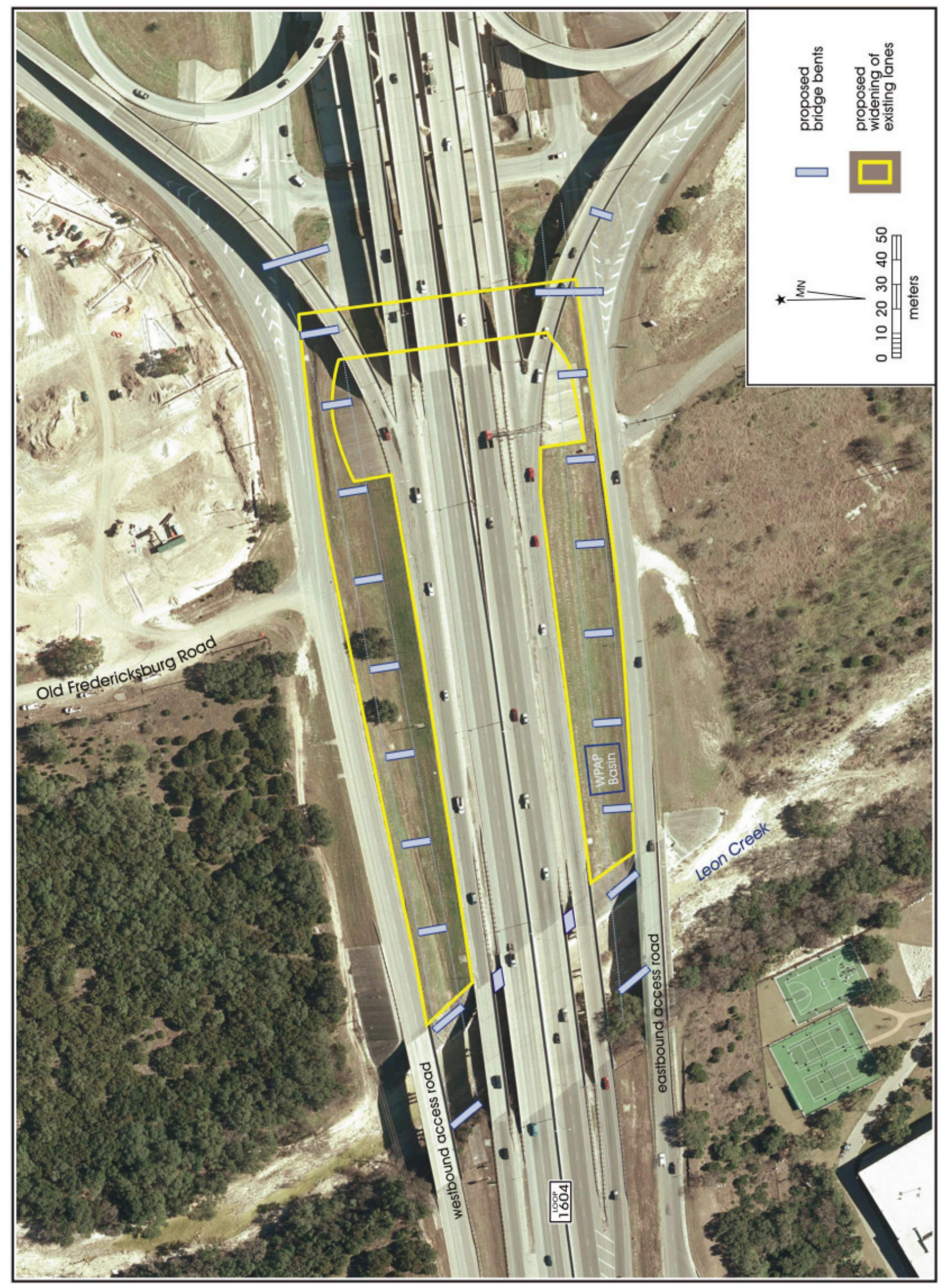

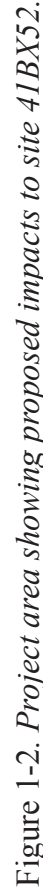


below surface adjacent to the creek. In addition to the bridge bents, a Water Pollution Abatement Plan (WPAP) basin will be placed within the median on the south side of the project area. The WPAP basin will measure approximately $20-\mathrm{x}-$ $14-\mathrm{m}$ in size and will be approximately $6 \mathrm{~m}$ deep.

The National Environmental Policy Act (NEPA) requires consideration of important historic, cultural, and natural aspects of our national heritage. Important aspects of our national heritage that may be present in the project corridor have been considered under Section 106 of the National Historic Preservation Act of 1966, as amended. This act requires federal agencies to "take into account" the "effect" that an undertaking would have on "historic properties." Historic properties are those included on or are eligible for inclusion on the National Register of Historic Places (NRHP) and may include structures, buildings/districts, objects, cemeteries, and archeological sites.

In accordance with the Advisory Council on Historic Preservation (ACHP) regulations pertaining to the protection of historic properties (36 CFR 800.4), federal agencies are required to identify and evaluate historic-age resources [properties that are 50 or more years old] for NRHP eligibility; subsequently assess the effects that the undertaking would have on historic properties and; if the effects are adverse, develop a treatment plan for the mitigation of effects. These steps shall be completed under terms of the First Amended Programmatic Agreement (PA) (2005) authorized among the Federal Highway Administration (FHWA), the ACHP, the Texas State Historic Preservation Officer (SHPO), and Texas Department of Transportation (TxDOT) on December 29, 2005. The PA outlines a streamlined approach for conducting Section 106 consultation and review with the SHPO and ACHP and other consulting parties. The document provides for (under certain conditions) authority to TxDOT Cultural Resource Management (CRM) staff to identify and evaluate cultural resources and, when historic resources are present, assess potential project impacts and/or effects without conducting individual consultation and review with SHPO. The documentation of undertakings having no effect on historic properties and reviewed by TxDOT in this manner is sent to the SHPO and the FHWA as quarterly reports for review.

If an effect is determined to be adverse, steps must be taken to minimize and/or mitigate the adverse effect. The consultation process of identification, evaluation, and assessment used to address the requirements of Section 106 of the NHPA is codified in the PA. If a transportation activity will adversely affect an historic property and includes the proposed taking or use of the property for a transportation activity, the undertaking must address the requirements of Section 4(f) of the USDOT Act of 1966. If a finding of Section 4 (f) is determined, considerations must include any feasible and prudent alternatives and planning to minimize harm. The Section 4(f) process also applies to the use of public parks, recreational areas, and wildlife refuges.

This project also falls under the purview of the Antiquities Code of Texas (ACT), because it involves "lands owned or controlled by the State of Texas [or any city, county, or local municipality thereof]". As the project would involve state purchase of ROW, or lands belonging to local municipalities and of counties, under jurisdiction of the TAC, historic properties would also be considered under provisions of the Memorandum of Understanding (MOU) between the SHPO and TxDOT. The ACT requires evaluation of historic and prehistoric resources under state or local government control to determine for designation as State Archeological Landmarks (SAL), and as such requires that each be evaluated for its "significance". Significance standards for the code are outlined under Chapter 26 of the Texas Historical Commission's (THC) Rules of Practice under Procedure for the TAC and closely follow federal standards discussed in the Secretary of the Interior's Standards and Guidelines but also include additional designation criteria.

\section{Project Setting}

The project area is situated in northwest Bexar County offLoop 1604. Leon Creek bounds the site to the west. The northern, eastern and southern boundaries of the site have never been well defined (see THC 2008 and Collins et al. 2003). 41BX52 is in the immediate environs of the meandering Leon Creek and is situated on a point bar. The opposite western bank of Leon Creek appears to lack soil deposits as the result of normal stream flow erosion and it is considered the concave bank (Waters 1992). Leon Creek flows at a rate of less than $1 / 3$ of a liter a per second, and originates from the Glen Rose and Edwards formation, 10 kilometers upstream from the site. Current flow rates have been impacted by modern groundwater pumping (Brune 1981).

Elevations in the project area range from approximately 940 to 950 feet AMSL. The nearest archeological site and the only site within a $1 / 2$ mile radius is $41 \mathrm{BX} 1064$, located on the opposite bank of Leon Creek. The site was recorded in the mid 1990s and is described as a scatter of burned rock and lithic debris eroding out of a foot trail along the western banks of Leon Creek (B. A. Meissner, personal communication, 2006).

41BX52 is within the boundaries of the Edwards Plateau. The Edwards Plateau gradually slopes to the southeast and ends in the Balcones Escarpment (Taylor et al. 1991). 
The limestone based Edward's Plateau is characterized by spring-fed, perennial streams that flow across the Balcones Escarpment (SCTRWPGP 2008). Vegetation in the Edwards Plateau consists largely of Bald cypress (Taxodium distichum), live oak (Quercus virginiana), cedar elm (Ulmus crassifolia) and several species of grasses that include bluestem (Schizachyrium and Andropogon spp.), gramas Boutelous spp.), Indiangrass (Sorghastrum nutans), common curlymesqutie (Hiaria belangeri), buffalograss (Buchloe dactyloides) and Canadian wild rye (Elymus Canadensis).

Bexar County also falls within two of the six biotic provinces described by Blair (1950): the Tamaulipan and the Balcones. The Balcones province includes the Edwards Plateau, which also includes vegetation typical of its neighboring zones and is therefore quite diverse. It supports species typical of east Texas, the Trans-Pecos, and grasslands. Juniper and mesquite trees dominate today though the area once supported a deciduous forest and wildlife including bison, wolf, and antelope that are gone today (Black 1989b).

The Tamaulipan province spans from the Balcones Escarpment south into northeastern Mexico east of the Sierra Madre. The region is generally covered with thorny brush species like acacias and mesquite but likely supported more grasses prior to historic modifications to the land (Black 1989b).

South Central Texas is humid subtropical with hot and humid summers (Taylor et al. 1991). The hot weather is persistent from late May through September. The cool season begins about the first of November and extends through March. Winters are typically short and mild with light precipitation. Precipitation in the San Antonio area averages about 27.63 inches a year (SRCC 2007; based on monthly averages from 1971 to 2000). Monthly temperature averages range from $51^{\circ} \mathrm{F}$ in January to $83.5^{\circ} \mathrm{F}$ in August.

\section{Culture Chronology}

The prehistoric occupation of Bexar can be divided into three culture periods: the Paleoindian, Archaic, and Late Prehistoric, periods. These periods are defined by changes in hunting and gathering technologies as well as material culture. Collins' culture chronology for Central Texas (1995 and 2004) is used as a basis in this section supplemented by the results of current research. A brief synopsis of the paleoenvironment for each period is also included in this section.

\section{Paleoindian}

The Paleoindian period is marked by the first signs of human populations in the New World. It coincides with the end of the Pleistocene and spans roughly from $11,500-8800 \mathrm{BP}$ (Collins 1995 and 2004). Environmental data suggest that the climate during the Late Pleistocene was wetter and cooler than it is today (Mauldin and Nickels 2001; Toomey et al. 1993), though gradually drier and warmer into the Early Holocene (Bousman 1998).

In the past, researchers generally thought of Paleoindian populations as groups of hunter-gatherers ranging over wide areas in pursuit of megafauna. This perception of Paleoindian peoples is now being reassessed. Although exploiting Late Pleistocene megafauna may have constituted a large part of Paleoindian subsistence, these peoples are perhaps better characterized as generalized hunter-gatherers with subsistence including small game and plants. The Lewisville site (Winkler 1982) and the Aubrey site (Ferring 2001), in north Texas, possess faunal assemblages with a wide range of taxa (including large, medium and small mammals). Little information seems to be available on the consumption of plant resources during this period. According to Bousman et al. (2004) the Late Paleoindian component at the WilsonLeonard site reflects diverse exploitation of riparian, forest and grassland species. Skeletal analysis of Paleoindian remains indicates that the diets of the Paleoindian and later Archaic hunter-gatherers may not have differed so greatly (Bousman 2004 after Powell and Steele 1994).

Clovis and Folsom fluted projectile points are typically associated with the early part of the Paleoindian period. Projectile points, such as Plainview, Dalton, Angostura, Golondrina, Meserve, and Scottsbluff are associated with the later part of the period. Site types associated with the Clovis subperiod include camp, lithic procurement, kill, cache, ritual and burial sites (Collins 1995). Meltzer and Bever (1995) have documented 406 Clovis sites in Texas. One of the earliest documentations of a Paleoindian site, 41RB1, was a small playa site near Miami in Roberts County, Texas (Bousman 2004:15). According to radiocarbon assays the maximum age for the Miami site is 11,415 \pm 125 BP (Bousman 2004: 47).

Sites in Bexar County that reportedly possess Paleoindian components (other than Pavo Real) include St. Mary's Hall (Hester 1978 and 1990) and the Richard Beene site (Thoms et al. 1996; Thoms and Mandel 2006). St. Mary's Hall, 41BX229, is located in northern San Antonio, Bexar County. The site was first encountered in 1972 during the construction of a house just outside the property of St. Mary's Hall institution (Hester 1978). The Richard Beene site, 41BX831, is located along the Medina River in southern Bexar County (Thoms et al. 1996). Early Holocene soils are present on the site with evidence of a possible rock lined oven (Bousman 2004:46). 


\section{Archaic Period}

The Archaic period spans from ca. $8800 \mathrm{BP}$ to $1200 \mathrm{BP}$. This period can be further divided into the Early Archaic, Middle Archaic and Late Archaic phases. During the Archaic, there is a shift in subsistence patterns and more of an emphasis on the exploitation of specific local environments. Differences between phases are marked by changes in material culture and site characteristics. Hunting strategies focus mainly on medium to small game with a continued foraging of plant resources.

\section{Early Archaic}

The Early Archaic spans from 8800 to 6000 BP Early Archaic projectile point styles include Angostura, Early Split Stem, Martindale and Uvalde (Collins 1995). The climate during this subperiod is drier with a return of grasslands (Bousman 1998). Megafauna of the Paleoindian period could not subsist in the new ecosystem and gradually died out. With the extinction of megafauna, the Early Archaic exploitation of medium to small fauna intensified.

Data recovered from the Wilson-Leonard site reveals the continuation of projectile point forms and the use of small to medium size hearths. The appearance of earth ovens suggests a shift in subsistence patterns. Collins et al. (1998) states that the earth ovens at Wilson-Leonard were used to cook wild hyacinth along with aquatic and terrestrial resources. Information from Early Archaic human remains from Kerr County (Bement 1991) suggests a diet low in carbohydrates. Stable-carbon isotopes also are consistent with a low reliance on $\mathrm{C}_{3}$ plants (such as sotol and acorns) and animals that consume such vegetation (Johnson and Goode 1994:24).

\section{Middle Archaic}

Date ranges for the Middle Archaic span from 6000 to 4000 BP (Collins 1995; Weir 1976). There was a population increase during this subperiod (Johnson and Goode 1994). Climate was gradually drying as the Altithermal drought began. Demographic and cultural change likely occurred in response to these hotter and drier conditions. Middle Archaic projectile point styles include Bell, Andice, CalfCreek, Taylor, Nolan, and Travis. Johnson and Goode (1994) postulate that culture transmission from the Lower Pecos region explains the appearance of new point styles in the subperiod.

Middle Archaic subsistence focused on exploitation of nuts and riverine environments (Black 1989a). The accumulation of burned rock middens during the Middle Archaic coincided with this renowned exploitation of plant resources (Black 1989a; Johnson and Goode 1994). Current research has reassessed when the use of burned rock middens intensified. Data from Camp Bowie suggests that intensification occurred in the latter part of the Late Prehistoric period (Mauldin et al. 2003). Little is known about burial practices during this culture subperiod, though a sinkhole in Uvalde (41UV4) contained 25-50 individuals (Johnson and Goode 1994:28).

\section{Late Archaic}

The Late Archaic is the final phase subperiod of the Archaic period and spans from 4000-1200 BP (Collins 2004). The Late Archaic is marked by the introduction of Bulverde, Pedernales, Kinney, Lange, Marshall, Williams, Marcos, Montell, Castroville, Ensor, Frio, Fairland and Darl projectile points. During the early part of the Late Archaic, there are fluctuations in temperature and rainfall. Populations are believed to have increased through this period (Collins 1995).

Some researchers state the accumulation of burned rock middens ceased at this time, though as discussed in the Middle Archaic section, current research has challenged this notion (Black and Creel 1997; Mauldin et al. 2003). Skeletal evidence from Late Archaic cemeteries in Central and South Texas, suggests the region saw increasing population densities that may have prompted the establishment of territorial boundaries and resulted in boundary disputes (Nickels et al. 1998). Human skeletons dating to this subperiod of the Archaic have been found near the Edward's Plateau. Dental evidence shows a high rate of enamel hypoplasia indicating nutritional stress (Johnson and Goode 1994).

\section{Late Prehistoric Period}

This period begins ca. 1200 BP (Collins 1995, 2004) and lasts until the Protohistoric Period. The term Late Prehistoric is commonly used to designate the period following the Late Archaic in Central and South Texas. A series of distinctive traits marks the shift from the Archaic to the Late Prehistoric period, including the technological shift to the bow and arrow and the introduction of pottery. The period includes two Phases: The Austin Phase and the Toyah Phase.

At the beginning of this period environmental conditions were warm and dry (Nickels and Mauldin 2001). More mesic conditions appear to accelerate after 1000 BP. Subsistence practices remain relatively unchanged, especially during the Austin Phase. Projectile point styles associated with the Austin Phase include Edwards and Scallorn types while in the Toyah Phase the Perdiz projectile point is prevalent (Collins 1995). 
Most researchers agree the early Late Prehistoric period (Austin Phase) was a time of population decrease (Black 1989a:32). Radiocarbon data has revealed that a number of burned rock middens in Central Texas were used long after the Archaic and throughout the Late Prehistoric. Moreover, the "heyday of middenery began after A. D. 1 and peaked during the Late Prehistoric" (Black and Creel 1997:273). Radiocarbon dates from Camp Bowie middens concur with arguments set forth by Black and Creel (1997) that burned rock middens are primarily a Late Prehistoric phenomena (Mauldin et al. 2003).

Beginning rather abruptly at about $650 \mathrm{BP}$, a shift in technology occurred. This shift is represented by the introduction of blade technology, the first ceramics in Central Texas (bone-tempered plainwares), and the appearance of Perdiz arrow points, and alternately beveled bifaces (Black 1989a:32; Huebner 1991:346). Prewitt (1981) suggests this technology encroached from north-central Texas. Patterson (1988), however, notes the Perdiz point was first seen in southeast Texas by about $1350 \mathrm{BP}$, and was introduced to the west some $600-700$ years later.

Ricklis (1995) contends that ceramics became a part of the archeological record in Central Texas beginning between A.D. 1250 and A.D. 1300. Early ceramics in Central Texas are associated with Toyah Phase components and referred to as Leon Plain. The earliest dates for Leon Plain are relative and based on associations with "Toyah" assemblages. The Leon Plain ceramic type includes undecorated, bonetempered bowls, jars, and ollas with oxidized, burnished or floated exterior surfaces (Ricklis 1995). Although there is a typical set of attributes associated with Leon Plain, there is notable variation within the type (Black 1989a; Johnson and Goode 1994; Kalter et al. 2005). This variation is typically attributed to differences in manufacturing methods and cultural affiliation. Stable carbon and nitrogen isotope data suggests that vessels were utilized in the processing of bison bone grease/fat, mesquite bean/bison bone grease and deer/ bison bone grease (Quigg et al. 1993).

Huebner (1991) suggests that the sudden return of bison to South and Central Texas during the Late Prehistoric resulted from a xeric climate in the plains north of Texas and increased grass in the Cross-Timbers and Post Oak Savannah in northcentral Texas. Together these formed a "bison corridor" into the South Texas Plain along the eastern edge of the Edwards Plateau (Huebner 1991:354-355). Settlement shifts into rock shelters such as Scorpion Cave in Medina County (Highley et al. 1978) and Classen Rockshelter in northern Bexar County (Fox and Fox 1967) have been noted (Skinner 1981) during this time. Cemeteries from this period often reveal evidence of conflict (Black 1989a:32).

\section{Previous Investigations at Pavo Real}

41BX52 was first identified in 1970 by Bill Fawcett and Paul McGuff (THC 2008). Subsequent visits and limited survey deemed the site to be a large campsite that was Archaic in age. The site had clearly been impacted by mechanical clearing associated with the widening of Loop 1604 (see Collins et al. 2003). Data recovery excavations took place at $41 \mathrm{BX} 52$ between May 1979 and January 1980 by the Texas Department of Highways and Public Transportation (TDHPT). Figure 1-3 depicts the site boundaries and excavated areas as defined during the 1979-1980 investigations.

Excavations conducted by TDHPT revealed Paleoindian and Archaic components at the site. TARL was awarded a contract in 2000 by the Texas Department of Transportation (TxDOT) to analyze and write-up the material obtained from the 19701980 excavations at Pavo Real. Until the findings were published by Collins et al., in 2003, only minimal information had been published on the excavations conducted at 41BX52 (Henderson and Goode 1991; Martinez et al. 1994). The 1979-1980 excavations at the site focused primarily on the Paleoindian component. The remainder of this section summarizes the information reported by Collins et al. (2003) on the Pavo Real site, including the paleoenvironment, geomorphology, excavation methods and results.

\section{Geomorphology of 41BX52}

The geoarcheological assessment of the site was carried out by Charles Johnson and relied on depositional data collected from 16 backhoe trenches (Collins et al. 2003:39). Nine depositional zones were identified. Due to problems interpreting Johnson's notes and descriptions, Collins and Hudler (2003) combined Johnson's geological zones into "Suites" (see Collins and Hudler 2003a:36). Four such units were defined. The horizontal distribution of each Suite is depicted in Figure 1-4. Due to the nature of the landform and the bench created by Suite I, these suites, with the exception of Suite IV, are not present in all areas of the site.

Suite I was the oldest soil unit, comprised of fluvial and colluvial valley fills (Collins 2003). It was also described as a pedogenic calcium carbonate formation. This sequence was formed prior to the presence of humans in the area. Suite I varies in depth from 300.9 AMSL on the east- central part of the site to a low of 298.8 AMSL elevation near the southwestern edge. A bench, comprised of this suite, is 


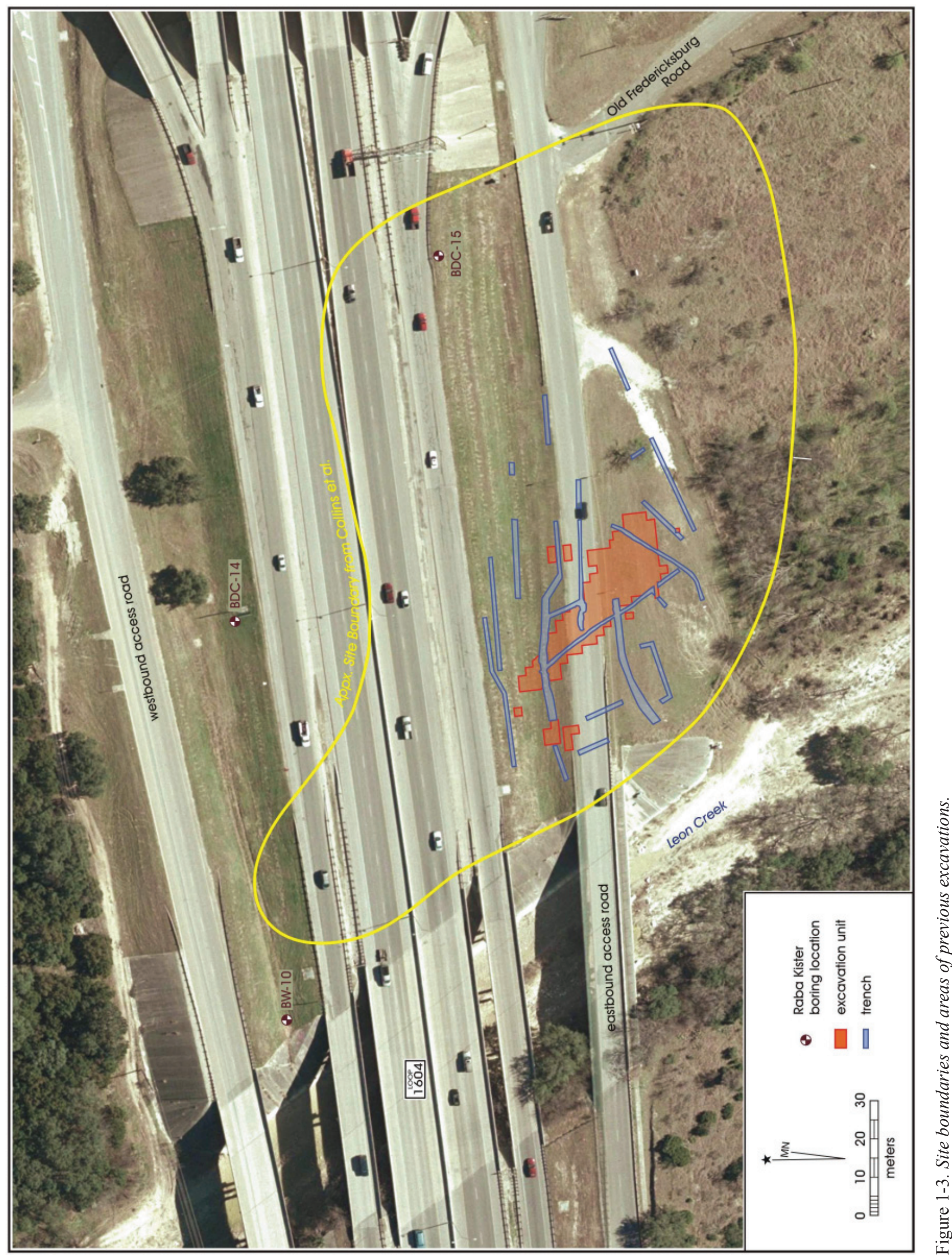




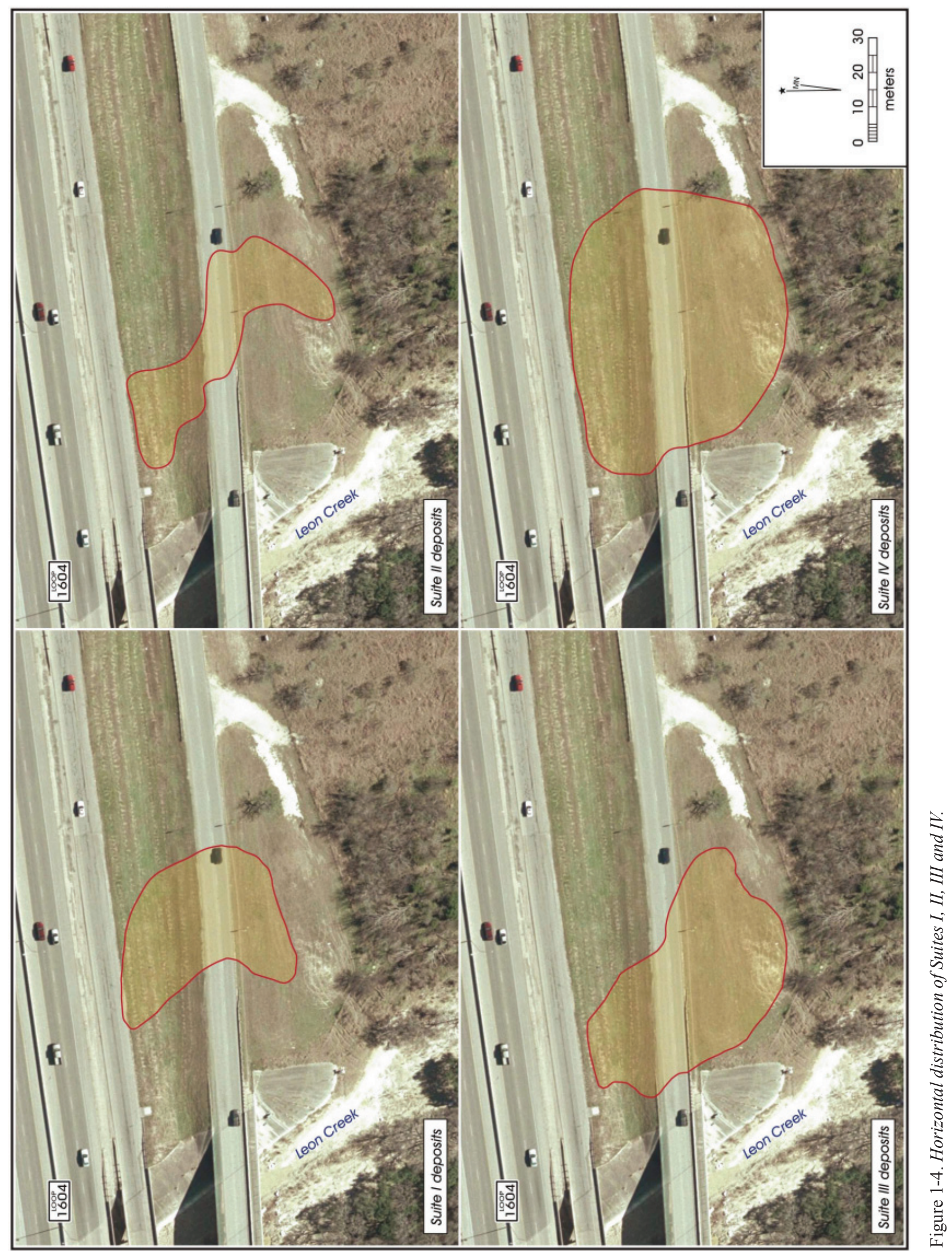


orientated northwest-southeast along the eastern edge of the site.

Suite II is comprised of fluvial deposits that lay atop Suite I. Suite II deposits contain sparse cultural material. Optically Stimulated Luminescence (OSL) dating of the sediments and radiocarbon dates of selected snails in this suite suggest that it was formed in the Late Pleistocene. OSL dating of Zone 9 (a stratigraphic layer identified within this suite) indicates an age greater than 14,880 years BP. The thickness of Suite II varies from 2.7 to $0.1 \mathrm{~m}$. The base of this suite is gravel that is topped by what Johnson called "mixed colluvium gravel and fine seds" (Collins 2003:47).

Suite III is the most arbitrary of the suites and it is made up of gravel zones interrupted by a sandy loam deposit in Zone 5. This suite contains the Paleoindian component of the site that is a mixture of Clovis and Folsom materials. It ranges in thickness from 0.1 to $1.8 \mathrm{~m}$. OSL dating of sediments from Zone 5 suggests that the burial of the associated cultural material occurred ca. 10,000 RCYA (Collins 2003:49) Radiocarbon dates suggest the suite is Archaic in age. Collins suggests that animal/insect burrowing; root disturbance and even human disturbance could explain the presence of Archaic charcoal.

Suite IV is described as a thin mix of fluvial and colluvial deposits that were formed during the Holocene. Much of this suite had been disturbed. Presumably, this suite contains the Archaic period cultural material, covers the entire site and is 0.3 to $0.75 \mathrm{~m}$ thick.

A micromorphological analysis of sediments from Zones 1, 3, 5, 7 and 9 was conducted in order to determine any evidence of post-depositional disturbances (Luchsinger and Goldberg 2003). Thin sections from soil monoliths that were extracted from backhoe trench profiles were used in the analysis. Results indicated that Zones 1 and 3, presumably from Suite IV, had been subjected to biological activity, such as root activity and "the production of secondary carbonate" (Luchsinger and Goldberg 2003:69). Zones 7 and 9 (Suite II) also contained high amounts of organic matter. Furthermore, the presence of carbonates in the zones suggests wet conditions during their deposition in the late Pleistocene. The analysis of Zone 5 (the Paleoindian component in Suite III) indicated that this zone had the least amount of post-depositional change. Micromorphological analysis also revealed a difference between the upper and lower portions of Zone 5, though not enough for a stratigraphic break.

\section{Cultural Components, Excavation Strategies and Artifacts}

Initial excavation efforts in 1979 at 41BX52 were based on the assumption that the earliest time period represented at the site was an Early Archaic component. Archaic deposits ranged from 40 to $80 \mathrm{~cm}$ in thickness and were confined to Suite IV soils. The horizontal extent of the Archaic deposits was never determined due to construction disturbances that occurred prior to excavations. Suite IV was the most widely distributed suite on the site (see Figure 1-4). The Archaic deposits contained lithic artifacts and several features. The features included several hearths and a large burned rock midden (BRM). The largest feature recorded on the site was an annular burned rock midden (Feature 4) that contained two internal features (Black 2003). Radiocarbon dates indicate that the BRM was utilized during the Middle to Late Archaic. Dart points recovered from within and below the feature date from the Early Archaic (4000 B.C.- 2500 B.C.; Turner and Hester 1999) to as late as the Transitional Archaic period (300 B.C.- A.D. 700).

Once Paleoindian remains were encountered, toward the end of the project, the focus of excavations shifted. The mechanical stripping of 40 to 50 centimeters $(\mathrm{cm})$ of Archaic deposits was the first step in excavating the Paleoindian component. The investigation of most of the Archaic features was abandoned. Excavations were concentrated exclusively in Areas 3 and 4 where 155 test units were excavated into Paleoindian deposits (see Chapter 7 of Collins et al. 2003). Clovis and Folsom lithic artifacts were recovered mostly from Zone 5 in Suite III. The distribution of this component was calculated to be around $553 \mathrm{~m}^{2}$. Two features characterized by concentrations of lithic debitage were associated with the Paleoindian component and interpreted as knapping areas. OSL dates indicated that Zone 5 was buried 10,000 RYCA, in Folsom times, while radiocarbon dates yielded dates of 7000 $\pm 250 \mathrm{BP}$ and $2870 \pm 300 \mathrm{BP}$. Collins et al. (2003) believe a majority of the component was removed by excavations.

\section{Raba-Kistner Cores}

Three geotechnical cores were excavated within the project area by Raba-Kistner Consultants Inc, under contract with TxDOT in 2005 (see Figure 1-3). Two cores were located in the northern portion of the project area (BW-10 and BDC-14) and one was located on the southern median (BDC-15; see Figure 1-3). The coring results indicated the presence of at least 17 feet of fill in the northern median (BW-10) nearest Leon Creek. Water was encountered at 12 feet below the surface in this core. Below the fill matrix, sand and clay soils were present to a depth of 30 feet $(9.1 \mathrm{~m})$. BDC-14, also on the 
north side of Loop 1604, showed evidence of interchanging clay and limestone horizons. A clay horizon is present in the first 30 centimeters $(\mathrm{cm})$ followed by limestone that extends to a depth of $6 \mathrm{~m}$. Another clay zone is present between 6 to $7.6 \mathrm{~m}$ succeeded by limestone that reaches to $15 \mathrm{~m}$.

The sole core (BDC-15) excavated in the median on the south side of Loop 1604 was located near the main lanes (see Figure 1-3). This core contained a thin clay layer over limestone that extended to approximately $4.5 \mathrm{~m}$ (15 feet). The third zone consisted of clay with gypsum seams extending to a depth of $15 \mathrm{~m}$.

Overall, the coring indicated that fill matrix was deepest in both medians near the Leon Creek. The cores also suggest that the fill decreases in thickness as one moves to the east and away from the creek channel. 


\section{Chapter 2: Project Activities}

Archeological investigations at the Pavo Real site were conducted by the CAR in three phases. The first phase of archeological investigations included mechanical coring and backhoe trenching. The second phase included two 2-x-2-m block excavations. The final phase included the excavation of a 1-x-2-m block and a backhoe trench. The coring and trenching phase was conducted under a TxDOT General Services Contact with Raymond P. Mauldin serving as Principal Investigator. The remaining work was contracted under HNTB with Steve A. Tomka serving as Principal Investigator. All phases of archeological work were performed under Texas Antiquities Permit No. 4092. This chapter outlines the scope of work for each phase of the fieldwork.

\section{Mechanical Coring and Trenching}

The first phase of archeological investigations conducted by the CAR included mechanical coring and trenching. This work was conducted under TxDOT work authorization \#WA 57515SA005. Based on findings documented in Collins et al. (2003), CAR assumed that the Paleoindian deposits at 41BX52 had substantial research potential. If such deposits remained, the site would be eligible for nomination to the National Register of Historic Places (NRHP) under criterion D. To determine the depth of construction fill and the presence, location and if possible, condition of any remnant archeological deposits, it was proposed that up to six sediment cores were to be excavated within the Areas of Potential Effect.

In addition to the six cores, up to six backhoe trenches were also proposed to further explore the extent of fill and disturbances on the site and to confirm the coring results. Upon completion of this first phase of testing, it was suspected that Suite II (Pre-Clovis) soils and possibly Suite III soils (associated with the Paleoindian component of the site) may lay beneath the thick fill revealed in one of the backhoe trenches placed adjacent to Leon Creek.

An electronic post-field report was provided to TxDOT after the completion of the fieldwork. This electronic communication indicated that no archeological deposits had been identified but that Suite II soils possibly associated with a Pre-Clovis component were identified. CAR recommended further work. A written report was submitted to TxDOT on January 15, 2007.

\section{Block Excavations}

The second phase of archeological investigations included mechanical stripping of fill and the placement of two 2-x2-m hand-excavated blocks to pursue two objectives: 1) seek datable samples from the remnant Suite II deposits identified in BHT 1 and; 2) determine whether Suite III deposits remain buried on site and if they are present recover a representative sample of the Paleoindian materials.

According to the data presented by Collins et al. (2003:Figures 31 and 29), the depth below surface at which Suite III deposits were anticipated to be present ranged from 2.45 meters below surface (mbs) in the area of the bridge bent to $1.86 \mathrm{mbs}$ where the proposed basin will be located (Figure 1-2). Suite II deposits were expected to be at $3.25 \mathrm{mbs}$ in the bridge bent area and $2.9 \mathrm{mbs}$ in the proposed basin area.

Due to the expected depth of the Suite III and II deposits and to allow their investigation through hand excavations, CAR mechanically stripped the fill layer. The area stripped measured approximately $17 \mathrm{~m}$ in length and $8 \mathrm{~m}$ in width to a target depth of $1.5 \mathrm{mbs}$ to ensure that a sufficient buffer was maintained above potential Suite III deposits. Careful monitoring of the mechanical stripping was conducted.

Once the fill was removed, CAR placed two 2-x-2-m blocks within the stripped area in portions of the median to be impacted by the bent and the basin. The purpose of the units was to determine if Suite III and Suite II deposits were in the APE. Adequate sampling of the deposits was necessary and required excavations to reach a maximum depth of 1.5 $\mathrm{m}$ below the stripped surface. The SOW submitted for this phase of the project called for the extraction of sediment samples for OSL dating from Suite II deposits.

\section{Additional Test Units and Backhoe Trench}

The lack of Paleoindian diagnostics and the preliminary geomorphological interpretations of the stratigraphy prompted CAR to recommend the excavation of an additional 1-x-2-m unit. Based on the stratigraphic assessment it seemed that the location of any Paleoindian-age strata was east of the block excavations. There was a small area (less than $3 \mathrm{~m}$ wide) between the eastern edge of eastern block (Block 2) and the western edge of the original excavation block (conducted 
in 1979-1980) where undisturbed Suite III deposits may be preserved.

CAR terminated the excavation of the western-most block (Block 1) and with concurrence from TxDOT reallocated the remaining 10 levels to the excavation of the 1-x-2-m unit. It was CAR's assessment that this strategy was most likely to reveal any remaining Clovis-Folsom age NRHP-eligible deposits that may still be present on site. CAR also requested HNTB and TxDOT approval of the excavation of a backhoe trench connecting the two $2-\mathrm{x}-2-\mathrm{m}$ excavation blocks to allow for geomorphic examination and description of the strata spanning both blocks.

We also proposed to collect paired samples of Rabdotus snails and bulk sediments for radiocarbon dating from the walls of Block 1 in order to assess the stratigraphic interpretation outlined above. TxDOT concurred with the reallocation of the 10 levels, the backhoe trench and collecting the snail and sediment samples. Collected samples were not to be submitted for analysis. 


\section{Chapter 3: Field and Laboratory Methods}

Several excavation strategies were used during the testing of the site. The first phase of excavations at 41BX52 involved mechanical coring and trenching. Block excavations were conducted in the second phase. One additional test unit (1-x-2 $\mathrm{m})$ and mechanical trenching comprised the third phase of archeological work at 41BX52. This chapter presents the field and lab methodology utilized during the project.

\section{Mechanical Coring}

Six cores were excavated in the northern and southern medians of the project area, positioned to avoid utilities and previous archeological excavation areas. Coring was performed with an Eijkelkamp percussion drilling set and its accompanying gouges ranging in diameter from 10 to $4 \mathrm{~cm}$, depending on depth. Coring ceased upon reaching bedrock or coarse gravel. The depositional sequences within all cores were recorded in the field on appropriate forms. Each soil strata was measured to determine its thickness and depth below surface. Selected cores were photographed.

\section{Backhoe Trenches}

Seven backhoe trenches were excavated during the field investigations. Backhoe trenches were placed in areas that were void of utilities. The depth of the trenches varied from $70 \mathrm{~cm}$ below surface (cmbs) to $274 \mathrm{cmbs}$. Trenches exceeding $1.5 \mathrm{~m}$ in depth were benched. The length of the trenches ranged from 4 to $8 \mathrm{~m}$. The width of trenches was approximately 1.5 to $2 \mathrm{~m}$. The maximum depth of the backhoe trenches was $2.74 \mathrm{~m}$, the deepest the backhoe equipment could reach. Due to safety issues, beyond the depth of 1.5 $\mathrm{m}$, no one was allowed to enter the trench, unless it had been benched. Selected backhoe trench walls were profiled and described by the project geoarcheologist.

\section{Block Excavations}

Block excavations consisted of two 2-x-2-m blocks that were comprised of four 1-x-1-m units each. Prior to hand excavations, CAR mechanically stripped an area (by means of a backhoe) measuring approximately $17 \mathrm{~m}$ in length and $8 \mathrm{~m}$ in width to a target depth of $1.5 \mathrm{mbs}$ to ensure that a sufficient buffer was maintained above potential Suite III deposits. Careful monitoring of the mechanical stripping was conducted. The excavated area had a gradual rise from west to the east end, with the western edge measuring over a meter in difference. Following the stripping, two 2-x-2-m excavation blocks were laid out. The two $2-x-2 \mathrm{~m}$ blocks were positioned two or more meters from the interior edge of the stripped area to provide a sufficient low bench to meet OSHA standards. An additional 1-x-2 m unit was opened (Block 3) just off Block 2. Each 1-x-1 m unit for each block was given a northing and easting designation and a unit number.

Elevations for the site were taken using a TxDOT benchmark that is located at the Loop 1604/IH-10 interchange. Two data were set for taking elevations during block excavations. The top of Datum 1 (used for Block 1) measured 300.6 amsl while Datum 2 (used for Block 2) was set at 300.8 amsl. String lines were set $10 \mathrm{~cm}$ below the top of the datum, from which and all elevations during block excavations were taken. In the individual block discussions elevations will be referred to by centimeters below string line (cmbsl).

All blocks were set up with a Total Data Station (TDS). All hand excavations were conducted in arbitrary $10-\mathrm{cm}$ levels. All soil recovered from the units was screened through 1/4inch mesh and all cultural material was collected and bagged by level. Appropriate unit level forms were maintained for each unit. Soil samples, measuring approximately one liter, were extracted from each excavation level in each of the two excavation blocks. The project archaeologist and project geoarcheologist inspected the walls of the excavated units. Selected unit walls were profiled and appropriate notes and digital photographs were taken. Artifacts, faunal and charred organic materials encountered in units were collected for potential analysis and curation.

\section{Archeological Laboratory Methods}

All archeological materials recovered during testing was fully analyzed, described, and reported. The objectives of these analyses was to a) identify the age, context, and condition of each archeological resource recorded during these investigations, and b) provide recommendations for further treatment of any archeological occurrences to determine their eligible for the National Register of Historic Places and formal designation as SALs if these determinations could not be made based on data gained during the intensive pedestrian survey.

All cultural materials and records obtained and/or generated during the project was prepared in accordance with federal 
regulation 36 CFR part 79, and $\mathrm{THC}$ requirements for State Held-in- Trust collections. Artifacts processed in the CAR laboratory were washed, air-dried, and stored in 4-mm zip locking archival-quality bags. Acid-free labels were placed in all artifact bags. Each label contains provenience information and a corresponding lot number written in pencil. Tools were labeled with permanent ink over a clear coat of acrylic and covered by another acrylic coat. In addition, a small sample of unmodified debitage from each lot was labeled with the appropriate provenience data. Artifacts were separated by class and stored in acid-free boxes. Digital photographs were printed on acid-free paper and labeled with archivally appropriate materials and placed in archival-quality sleeves. All field forms were completed with pencil. 


\section{Chapter 4: Results of Field Investigations}

This chapter presents the results of CAR's testing at 41BX52. As indicated in Chapter 2 of this report, the archeological testing at 41BX52 occurred in three phases. Mechanical coring and trenching of the site revealed thick fill near the creek overlying Suite II deposits (as described by Collins et al. 2003). The mechanical stripping and block excavations confirmed the presence of Suite II deposits as well as an Early Archaic component. This chapter is organized by the phases of archeological work conducted by CAR.

\section{Mechanical Coring}

CAR performed mechanical coring and trenching in the environs of site 41BX52 from November 13 thru 21, 2006, (Figure 4-1). Six cores and six backhoe trenches were excavated in order to determine the extent of construction disturbance and fill that had impacted the site. Mechanical coring and trenching took place in the median of the west (north side) and east bound lanes (south side).

Two cores were excavated ( 44 and $\mathrm{C} 5$ ) on the north side of the Loop 1604 West. C4 reached a terminal depth of 120 centimeters below surface $(\mathrm{cmbs})$ and contained three zones. Zone I consisted of a crushed/gravel limestone fill with limestone pieces about $5 \mathrm{~cm}$ in maximum dimension and extended to a depth of approximately $95 \mathrm{cmbs}$. Zone II was black (10YR 2/1) silty clay with gravel inclusions that reached to $105 \mathrm{cmbs}$. Zone III consisted solely of limestone that extended the remaining depth of the core to $120 \mathrm{cmbs}$. The coring mechanism was not able to penetrate beyond this depth. C5 contained three stratigraphic zones (Figure 4-2). Zone I was a dark brown (10YR 3/3) clay loam that contained a high percentage of limestone inclusions (60 to $70 \%$ ) and spanned to a depth of $40 \mathrm{cmbs}$. Zone II,

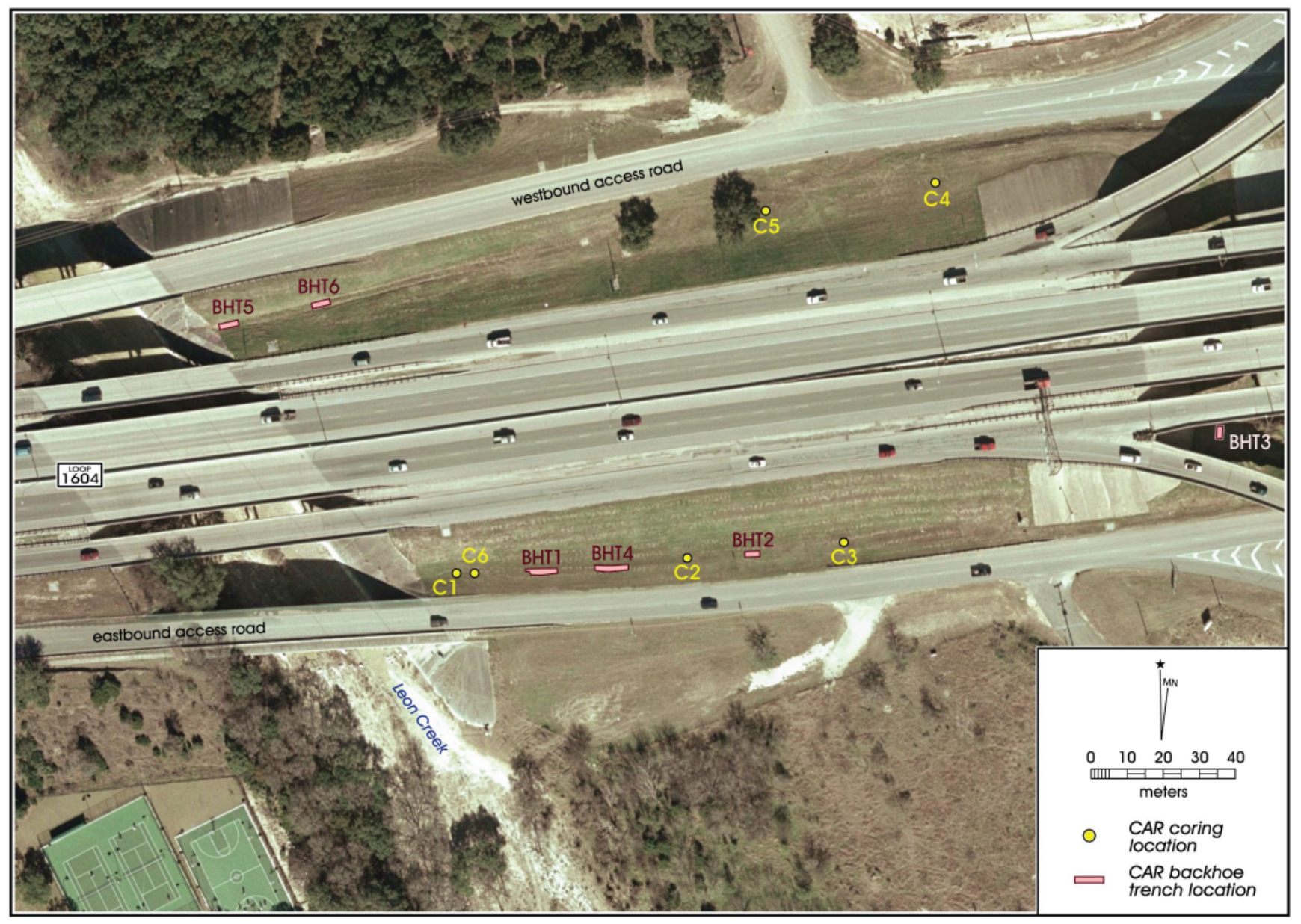

Figure 4-1. Aerial photograph of the project area showing the location of CAR's coring and backhoe trenches. 


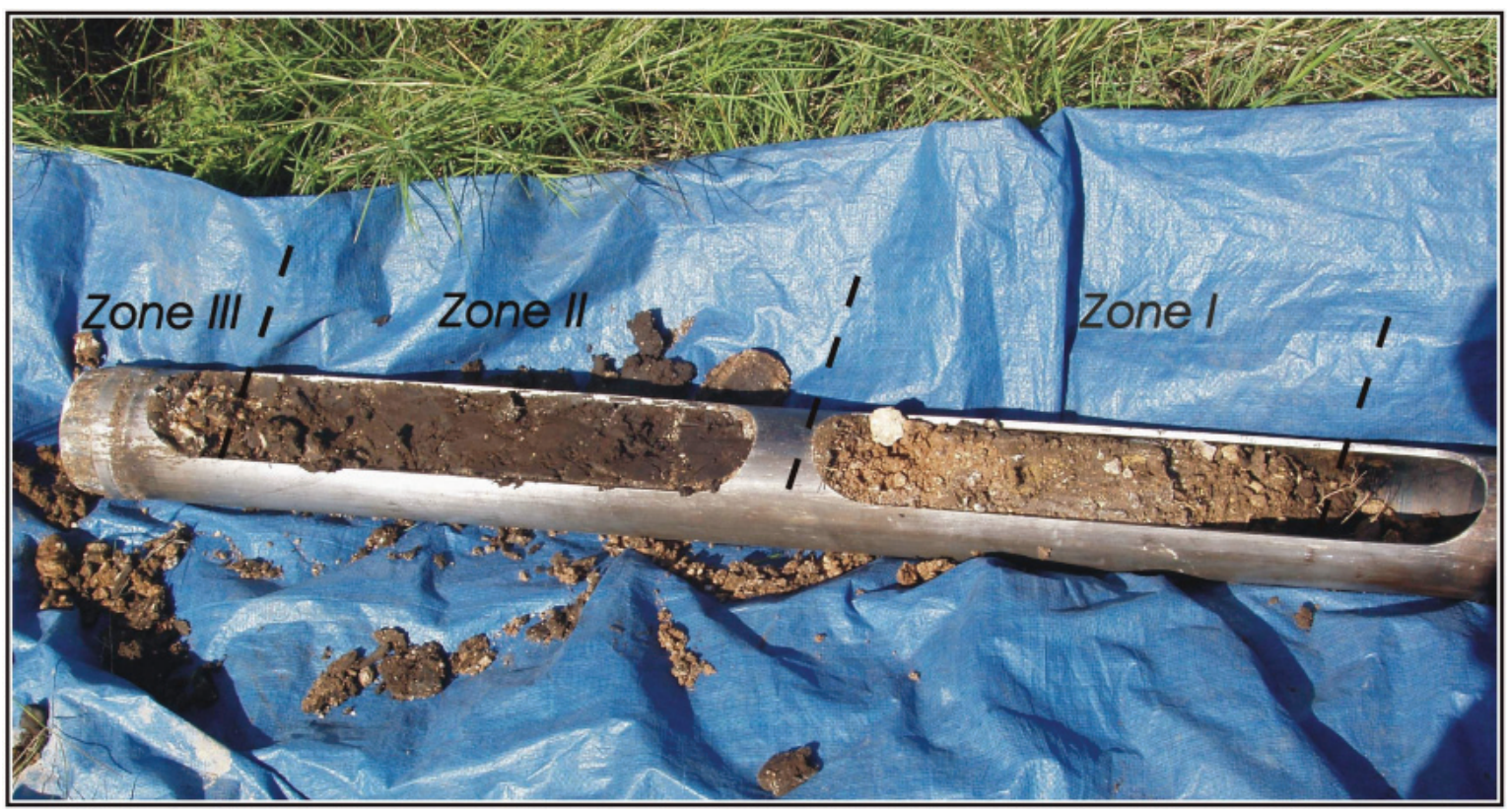

Figure 4-2. The stratigraphy of Core \#5.

consisted of a silty black (10YR 2/1) clay with no apparent inclusions and was present from 40 to $80 \mathrm{cmbs}$. Zone III contained a dark brown clay matrix with alluvial limestone gravel inclusions, which extended the remaining depth of the core to $92 \mathrm{cmbs}$. Coring past this depth was not possible.

Four cores $(\mathrm{C} 1, \mathrm{C} 2, \mathrm{C} 3$ and $\mathrm{C} 6)$ were excavated in the south side median within the APE. C1 was near the creek and was excavated to a depth of approximately $143 \mathrm{cmbs}$. The core consisted of limestone fill (Figure 4-3). C6 was only $2 \mathrm{~m}$ east of $\mathrm{Cl}$ and also consisted entirely of limestone fill, reaching a final depth of $137 \mathrm{cmbs}$. C2 was the deepest core excavated in the project area, reaching a

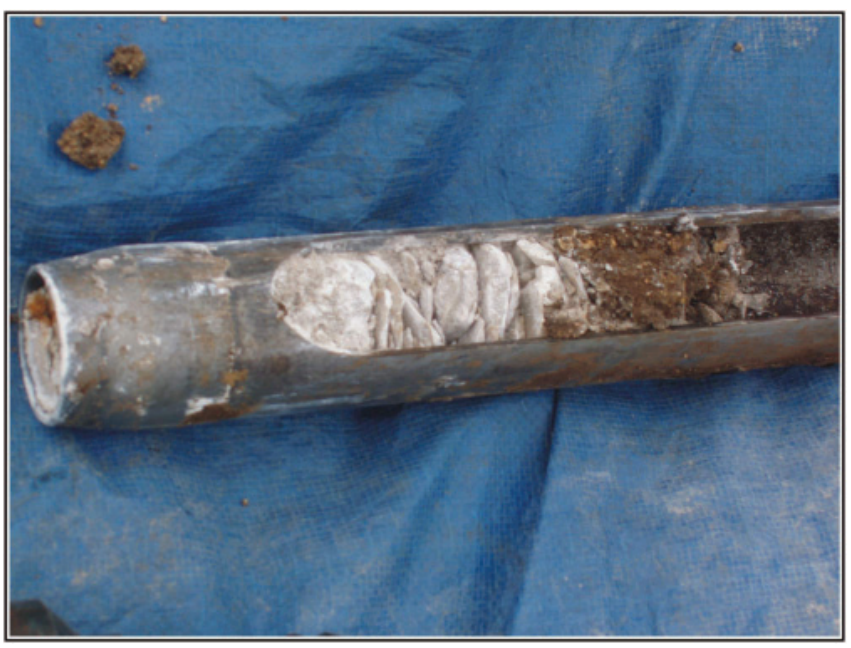

Figure 4-3. Limestone fill encountered at the bottom of Core \#1. terminal depth of $4.38 \mathrm{mbs}$ (14 feet). This core contained two zones. Zone I was a brown loam matrix mixed with fill material that reached a depth of $36 \mathrm{cmbs}$. Zone II was thought to be a dense fill material but later trenching efforts revealed it to be a Phase IV petrocalcic horizon (see results of backhoe trenching below) that reached $4.38 \mathrm{~m}$ below surface. Coring ceased at this depth due to problems retrieving the gouge (Figure 4-4).

C3 consisted of four stratigraphic zones and was excavated to a depth of $1 \mathrm{~m}$ (Figures 4-5). Zone I, similar to Zone I in C5, was dark brown clay with limestone inclusions that extended to a depth of $16 \mathrm{cmbs}$. Zone II was a dark reddish brown

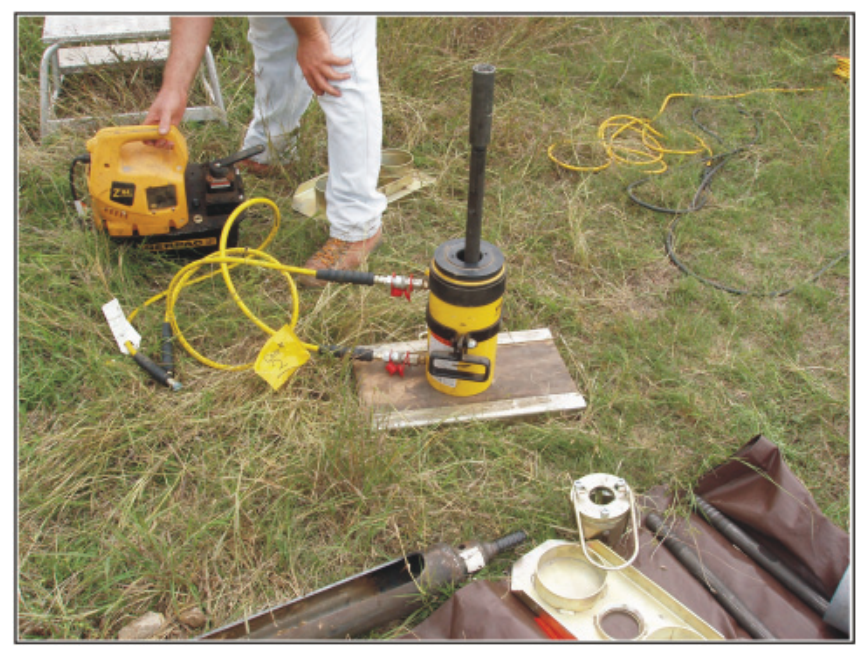

Figure 4-4. Hydraulic lift being used to extract the gouge from Core \#2. 

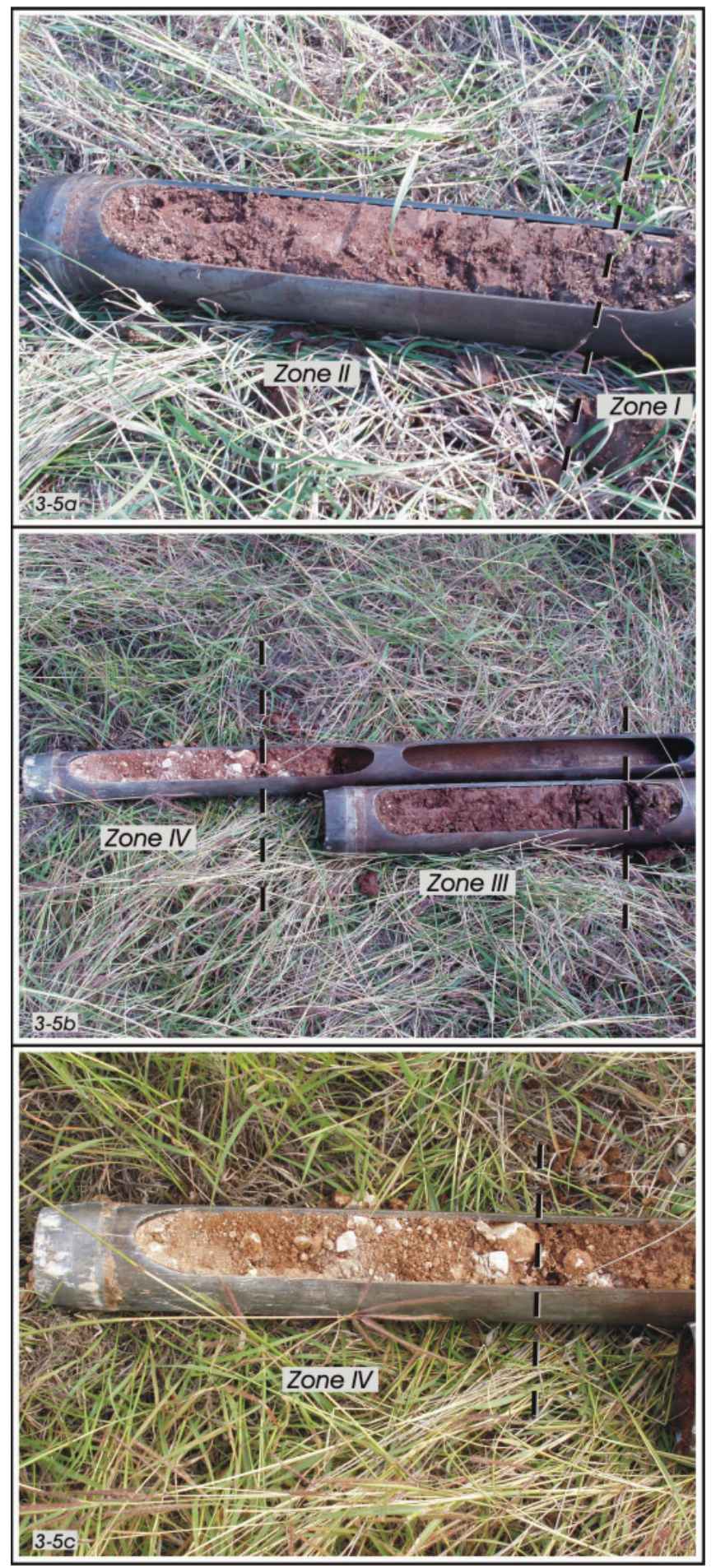

Figure 4-5. Core \#3 showing Zones I through IV.

(5YR 3/4) silty clay, with a few limestone inclusions, that terminated at $55 \mathrm{cmbs}$. Zone III was dramatically different from Zone II and contained a high percentage of limestone gravels (80 to $90 \%$ ) and was yellowish red (5YR 5/6) sandy loam. Zone III reached a depth of $84 \mathrm{cmbs}$. Zone IV consisted mostly of limestone inclusions that were reddish yellow
(5YR 7/6). Zone IV extended from $84 \mathrm{~cm}$ to $1 \mathrm{~m}$ in depth. The coring ceased at this depth.

\section{Backhoe Trenching}

Three backhoe trenches were excavated in the south side median of Loop 1604 (between the east bound main lanes and access road). Two were excavated in the north side median of Loop 1604 (between the west bound main lanes and access road) and one was dug beneath the IH-10/ Loop 1604 interchange overpass (see Figure 4-1). All backhoe trenches were dug parallel to the main lanes and the access roads.

\section{Backhoe Trench Descriptions}

BHT 1 was located on the south side of Loop 1604 and was $8 \mathrm{~m}$ long, $2 \mathrm{~m}$ wide and $2.6 \mathrm{~m}$ deep (see Figure 4-1). BHT 1 revealed remnant deposits identified as Suite II in the Pavo Real report (Collins et al. 2003). None of the gravel lenses identified by Collins in the Paleoindian levels (Suite III deposits) were observed in this trench. Close reading of Collins' description (Collins et al. 2003) and Johnson's profiles suggest that the deposit at the base of BHT-1 is Suite II, most likely situated in the area to the east of the end of the Suite III deposits (which comprised interbedded gravels and fine-grained alluvium within which the Folsom and Clovis occupations were situated) and west of the Suite I deposits (see Collins et al. 2003:43; Figure 4-6, Geological Profile 5B). The natural deposits exposed at the base of BHT-1 were comprised of two different deposits: a fine textured and a lower sandy deposit. The upper deposit consisted of a brown (7.5YR 5/4) loam to silty clay loam, within which were numerous calcium carbonate filaments (Figure 4-6). This deposit rested upon a strong brown (7.5YR 5/6) loam to sandy loam which contained fewer calcium carbonate filaments and appeared to dip to the west. These deposits are presumed to correlate with the mixed alluvium colluvium and the sandy alluvium of Suite II identified on Figure 4-5 in Collins et al. (2003). If the Suite III deposits are still present at the site, they are undoubtedly located to the west of BHT-1, but the clearly truncated nature of the deposits in this trench suggest that the Paleoindian age deposits have been removed from this location, if they were there before.

The second trench (BHT-2) was located to the east of BHT-1 (see Figure 4-1). The backhoe trench measured 3.3 $\mathrm{m}$ in length, $1.5 \mathrm{~m}$ in depth and $1.5 \mathrm{~m}$ in width. The trench revealed $25 \mathrm{~cm}$ of rubble limestone construction fill on top of a Pleistocene age alluvial deposit within which a phase IV petrocalcic horizon had formed. This deposit is undoubtedly the same as the Suite I deposits reported by Collins et al. (2003). A thin (10 to $30 \mathrm{~cm}$ ) weakly calcareous black to very 


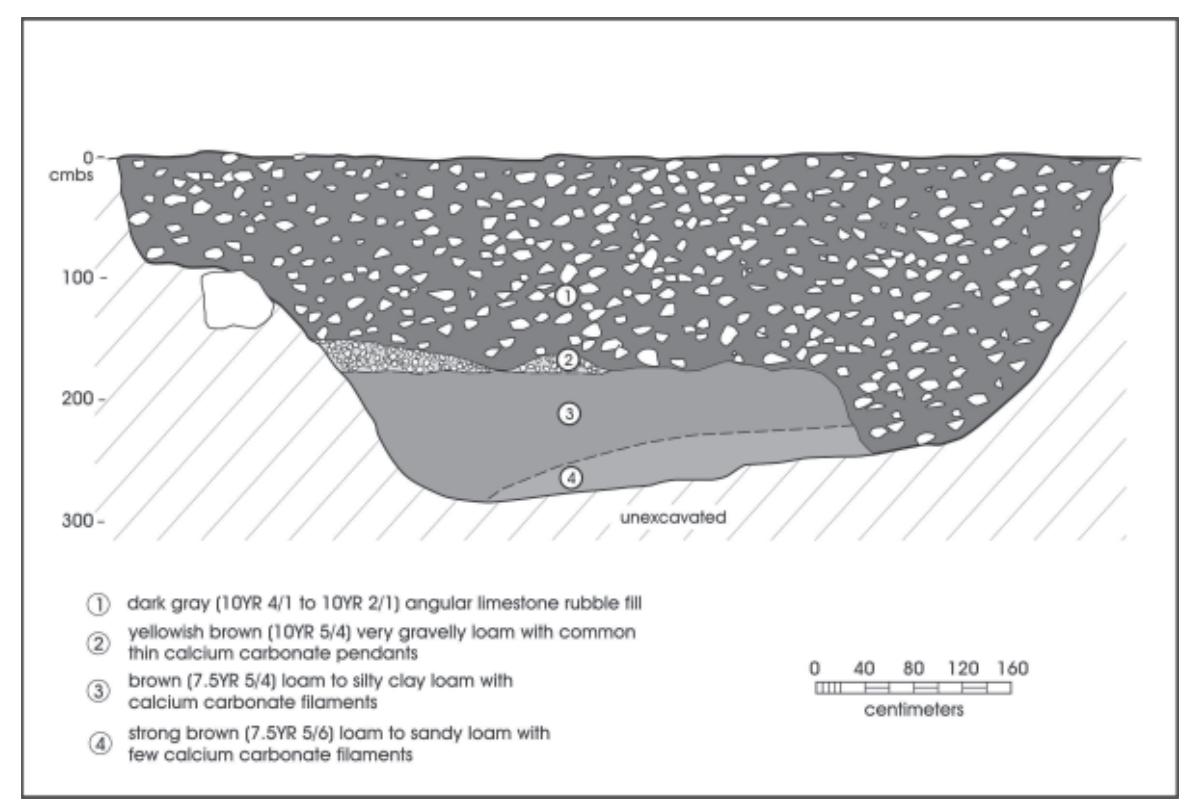

Figure 4-6. Profile of the north wall of Backhoe Trench 1 with Zones II, III and IV representing Suite II.

dark gray, strongly structured clay A horizon was observed resting on top of the $\mathrm{K}$ horizon, and the variable thickness of this deposit was due to the variable depth of disturbance and truncation associated with the construction fill. The $\mathrm{K}$ horizon has formed in an alluvial gravel, and was divisible into two parts (K1 and K2), the upper of which exhibited a laminar cap which graded to a massive zone of pedogenic carbonate within which alluvial gravels were suspended. Thin (ca. $1 \mathrm{~mm}$ ), dispersed, hard carbonate laminae were common throughout the lower part of the K1 horizon. The lower part of the petrocalcic horizon (K2) was a clastsupported gravel which was plugged with calcium carbonate and indurated. Beneath the $\mathrm{K}$ horizon was a yellowish red (5YR 5/6) sandy loam within which were numerous calcium carbonate nodules, filaments, and occasional discontinuous hard calcium carbonate laminae. A profile of this trench was not drawn due to the age of the soils.

BHT 3 was placed under the Loop 1604 overpass to the east of Leon Creek, on a low ( $\sim 2 \mathrm{~m})$ elevated bench. BHT 3 was $3.5 \mathrm{~m}$ long, $1 \mathrm{~m}$ wide and $70 \mathrm{~cm}$ in depth. An outcrop adjacent to the frontage road on the south side of Loop 1604 appeared to be a natural bedrock outcrop and BHT 3 confirmed this impression. Only $10 \mathrm{~cm}$ of brownish yellow (10YR 6/6) gravelly loam limestone construction fill was found resting on a noncalcareous black (10YR 2/1) clay, which in turn rested directly upon dense limestone bedrock (Figure 4-7). The bedrock surface was highly undulatory and the A horizon varied from as little as $20 \mathrm{~cm}$ to as much as 45 $\mathrm{cm}$ in thickness. No significant B horizon was observed in this trench, but such a horizon is probably locally present.
BHT 4 (8 $\mathrm{m}$ in length, $1.9 \mathrm{~m}$ wide and $2.74 \mathrm{~m}$ deep) was placed between BHT 1 and BHT 2, in hopes of extending the culturally relevant deposits to the east. Instead, this trench encountered between 1.0 and $1.3 \mathrm{~m}$ of rubble limestone construction fill resting upon truncated Suite I deposits, as described in Collins et al. (2003; Figure 4-8). In this trench the $\mathrm{K}$ horizon had been removed, apparently by construction, and only the loamy yellowish red alluvium (the lowest zone in BHT-2; Bk horizon) was present. This deposit was locally indurated and contained calcium carbonate nodules and discontinuous calcium carbonate laminae similar to that observed in BHT-2. Clearly, the bounding surface between the Late Pleistocene Suite I deposits and the Late Pleistocene-Early Holocene Suite II sediments is located between BHT-1 and BHT-4 and this is consistent with the long stratigraphic sections drawn by Johnson and reported by Collins et al. (2003:Figure 4-6).

BHT 5 was located immediately east of and adjacent to the concrete apron overlooking the modern channel of Leon Creek on the north side (north median) of Loop 1604. The

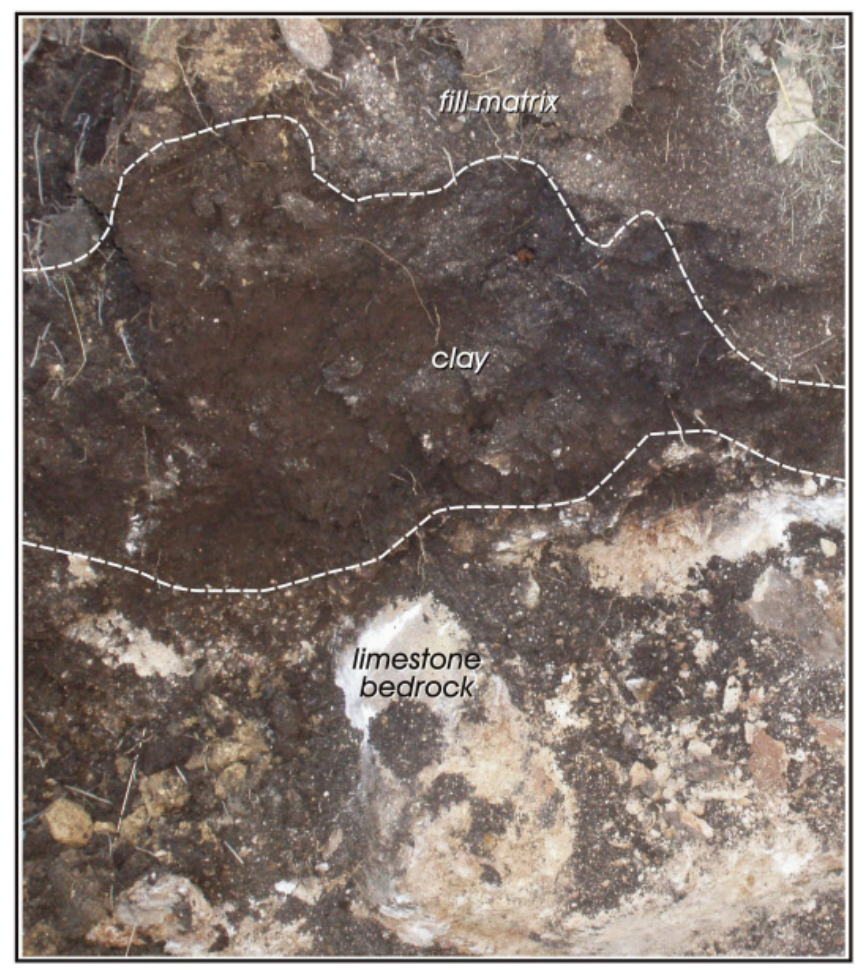

Figure 4-7. West wall of Backhoe Trench 3. 


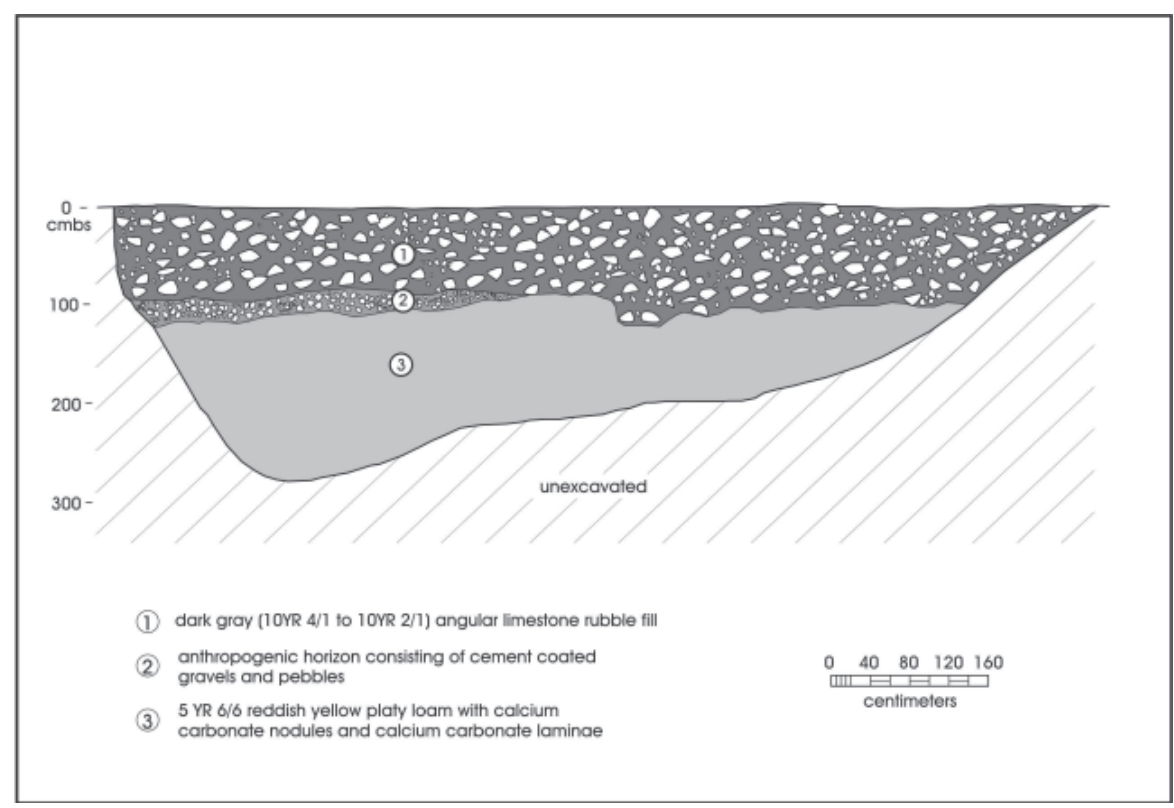

Figure 4-8. Profile of the north wall of Backhoe Trench 4.

trench was $5 \mathrm{~m}$ in length and $1.9 \mathrm{~m}$ wide. This trench exposed $2.5 \mathrm{~m}$ of construction fill, consisting of a large number of angular limestone boulders and gravels. The trench was terminated when the backhoe could no longer penetrate the massive rubble fill and therefore the natural alluvial deposits were not reached (Figure 4-9). A previous core (BW-10) by Raba-Kistner indicates that the construction fill in this location is approximately $4 \mathrm{~m}$ thick.

The last trench, BHT 6, measured $6 \mathrm{~m}$ in length, $2 \mathrm{~m}$ in width and $2.40 \mathrm{~m}$ in depth. BHT- 6 uncovered $1.5 \mathrm{~m}$ of rubble fill resting unconformably on top of the petrocalcic horizon formed in Suite I deposits. The latter exhibited a laminar cap and underlying massively indurated limestone gravel which was yellowish red (5YR 5/6). A profile of this trench was not drawn due to the age of the soils.

\section{Summary}

Coring through the fill material was difficult and impossible in most instances. Backhoe trenching on the south side of Loop 1604 indicated that as excavations moved east of the creek less fill was encountered. CAR trenching also revealed that the thickness of fill increased toward the west, approaching Leon Creek and was at least $2.5 \mathrm{~m}$ deep on the north side of the project area. Suite I deposits were evident in BHT 2 and 4. BHT 1 encountered Suite II deposits though evidence of Suite III deposits was not encountered. CAR's BHT 1 was located in the vicinity of backhoe trenching conducted during the 1979-1980 excavations (Figure 4-10; Collins et al. 2003, Trenches 1, 4W and 4E). The 1979-1980 trenches revealed remnants of Suite III and IV deposits in this locale.

Subsequent to the fieldwork, CAR staff visited the Texas Archeological Research Laboratory, reviewed 41BX52 documents curated there and discussed the location of the TDHPT excavation blocks versus the location of the CAR investigations with Dale Hudler. Based on copies of maps obtained from TARL, we were able to reconstruct and overlay the location of the TDHPT excavation blocks onto an aerial view of the project area while overlaying the CAR core and backhoe trench locations as well. These efforts caused us to modify our reconstructed location of blocks. We had initially located the excavation blocks further north than they appeared to have been dug. From this reconstruction, it appears that BHT 1 and BHT 4 may have been dug into TDHPT's original Trenches 1 and 4W, respectively. However, it is likely that both of the CAR trenches were wider than the

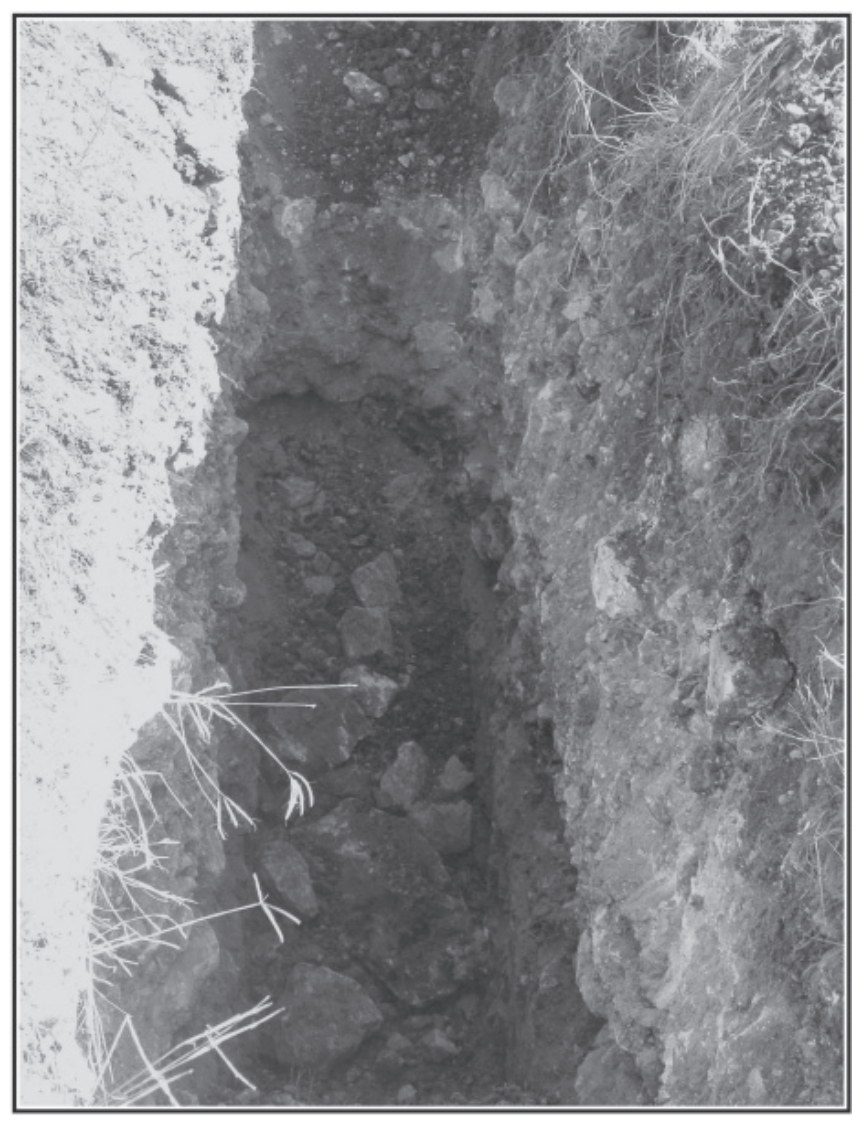

Figure 4-9. Fill material in Backhoe Trench 5. 


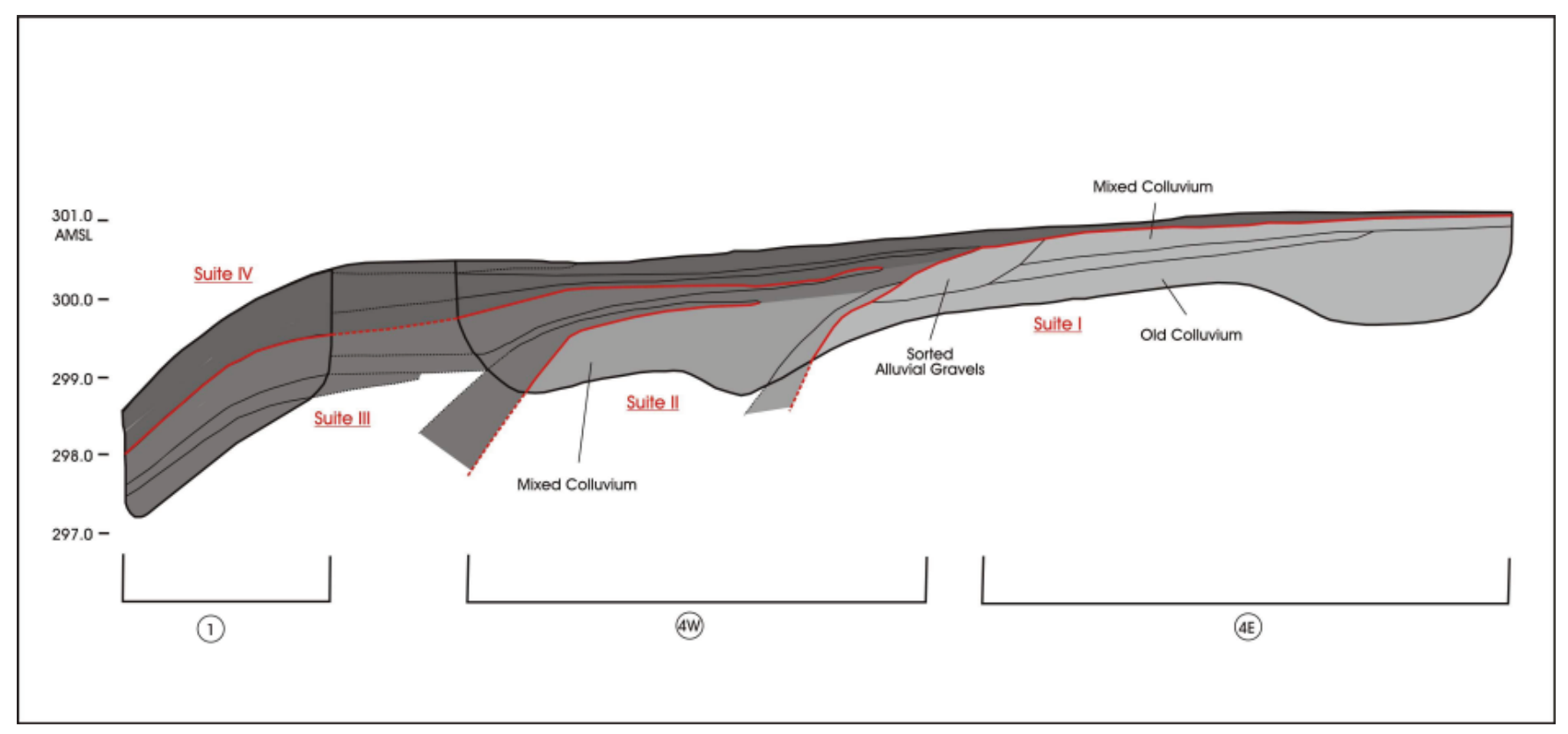

Figure 4-10. Profile of Trenches 1, 4W, 4E (from 1979-1980 project).

original TDHPT trenches because no disturbances were noted in the trench walls. We have also reviewed relevant portions of the Collins et al. (2003) report to determine the spatial extent of the Suite II deposits that contained cultural materials, although the age of these deposits could not be defined. Finally, we have communicated with Dr. M.B. Collins to inform him of our reconstruction of the location of the TDHPT excavation blocks. It is based on this combination of data and information that we proposed additional work in a limited portion of the southern median of Loop 1604.

\section{Block Excavations}

The second phase of archeological investigations included mechanical stripping of fill and the placement of two 2-x-2-m hand-excavated blocks to pursue two objectives; 1 ) seek datable samples from the remnant Suite II deposits identified in BHT 1 and; 2) determine whether Suite III deposits remain buried on site and if they are present recover a representative sample of the Paleoindian materials that would otherwise be disturbed by the proposed construction (Figure 4-11).

Prior to the hand excavations, an area measuring approximately $137 \mathrm{~m}^{2}$ of overburden was stripped to a depth of $1.5 \mathrm{~m}$ below the surface. Once the fill was removed, CAR placed two 2-x-2-m blocks within the stripped area in portions of the median to be impacted by the bent and the basin (Figure 4-12). Careful monitoring of the mechanical stripping was conducted. The depth of

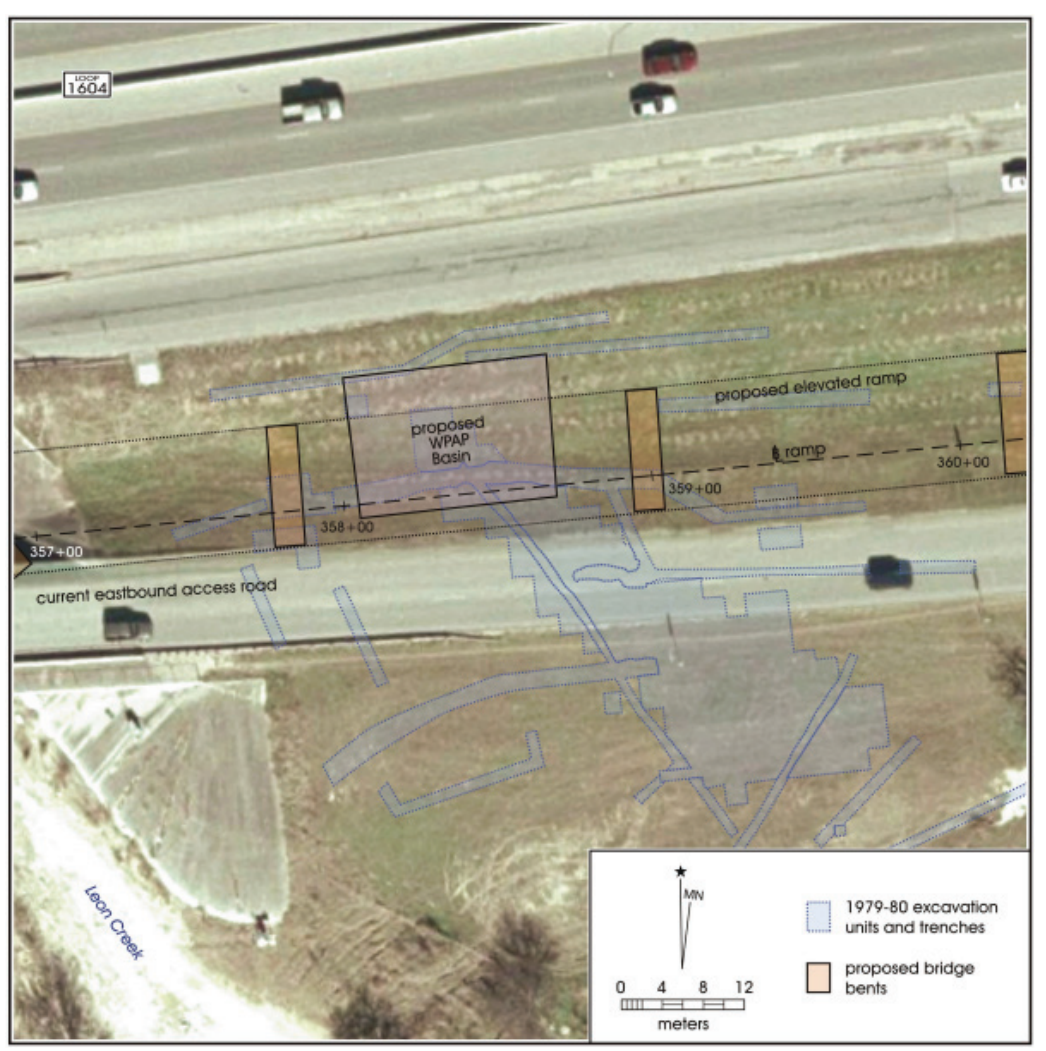

Figure 4-11. Location of proposed bridge bents and basin that will impact the southern portion of the project area. 


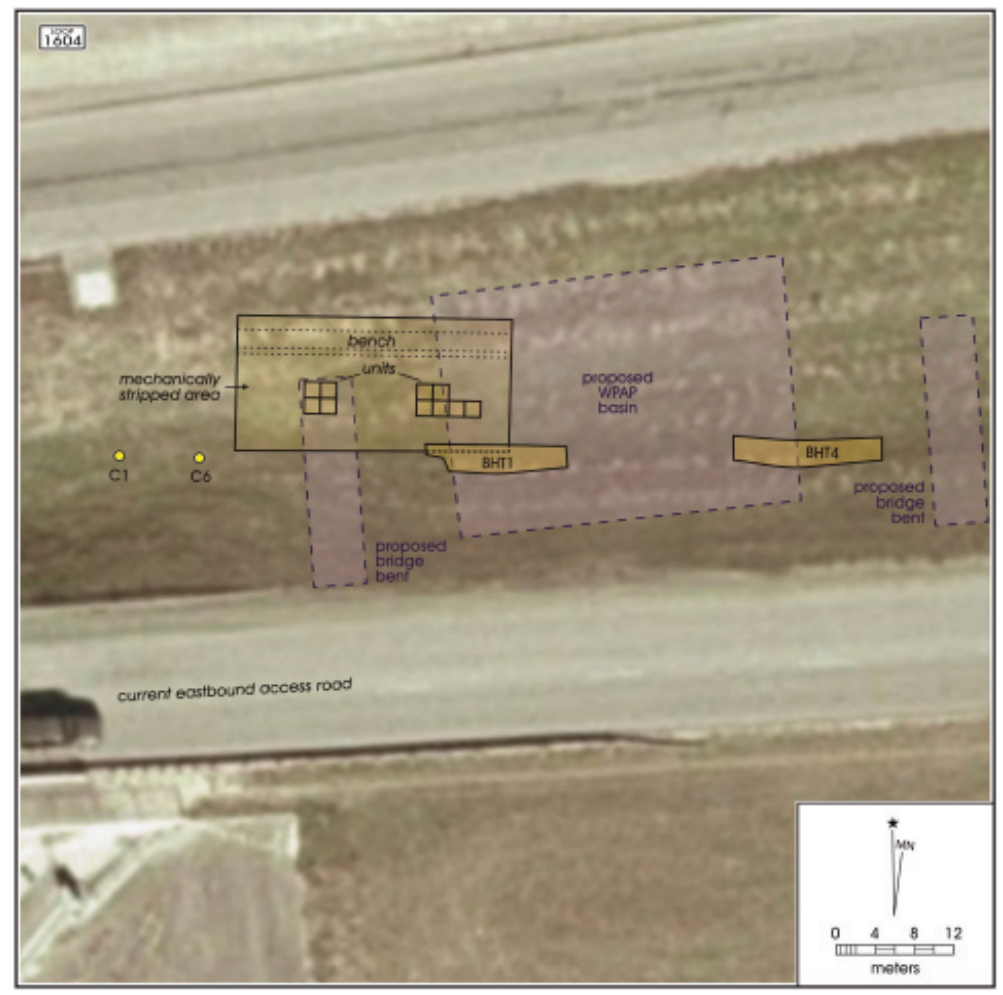

Figure 4-12. Proposed bridge bents, WPAP basin and area where mechanical stripping and block excavations were conducted. respectively. A total of $4.89 \mathrm{~m}^{3}$ of soil was excavated from Block 1.

The upper portions of Level 1 contained fill material that included asphalt and mechanically crushed rocks. A Perdiz point was found on the top of the stripped surface, adjacent to Block 1. It is associated with the disturbed matrix removed during mechanical stripping. Pebbles and gravels were present throughout the matrix in Block 1. In the southern test units ( 3 and 4 ) there was an increase in the density and size of inclusions beginning in Level $4(60-70 \mathrm{cmbsl})$. Cobble inclusions were fairly large $(>3 \mathrm{~cm})$. The dense concentration $(>50 \%)$ of gravel and cobbles decreased by Level 7 (90-100 cmbsl) though subsequent levels continued to contain gravel inclusions (15\%). A second layer of dense cobble/ gravel was present in Levels $9(110 \mathrm{cmbsl})$ and 10 $(120 \mathrm{cmbsl})$ and continued to the termination of the block excavations (Figure 4-14). The northern units ( 1 and 2) exhibited the same two concentrations of heavy inclusions as seen in the southern units. There was a decrease in inclusions beginning in Level 9 $(110 \mathrm{cmbd}$ ) that extended into Level 14 (the deepest level of the block in Test Unit 2; Figure 4-15).

construction fill was determined by the previous backhoe trenching conducted by CAR and was as deep as $1.5 \mathrm{~m}$ in the western portion of the excavated area. At times the imposing size of fill material made backhoe operations difficult. Excavations of Blocks 1 and 2 were conducted between May $7^{\text {th }}$ and May $24^{\text {th }} 2007$. Initial plans were to excavate 15 levels in both blocks. Due to inclement weather conditions, Block 1 was not completed to 15 levels; rather the remaining levels were allocated to the excavation of Block 3. Block 3 consisted of a 1-x-2-m excavation that extended southwest off Block 2 (Figure 4-13). Excavations of Block 3 were conducted June 1114, 2007. Cultural material retrieved from the block excavations consisted mainly of lithic material and burned rock. No features were revealed during the block excavations.

\section{Block 1}

In Block 1, Unit N21/E56 (Unit 1) ended at Level 13 (160 cmbsl) and N21/E57 (Unit 2) was excavated to Level 14 (170 cmbsl). Test Unit N20/E56 (Unit 3) was excavated to Level $11(140 \mathrm{cmbsl})$, while N20/ E57 (Unit 4) terminated at Levels $12(144 \mathrm{cmbsl})$,

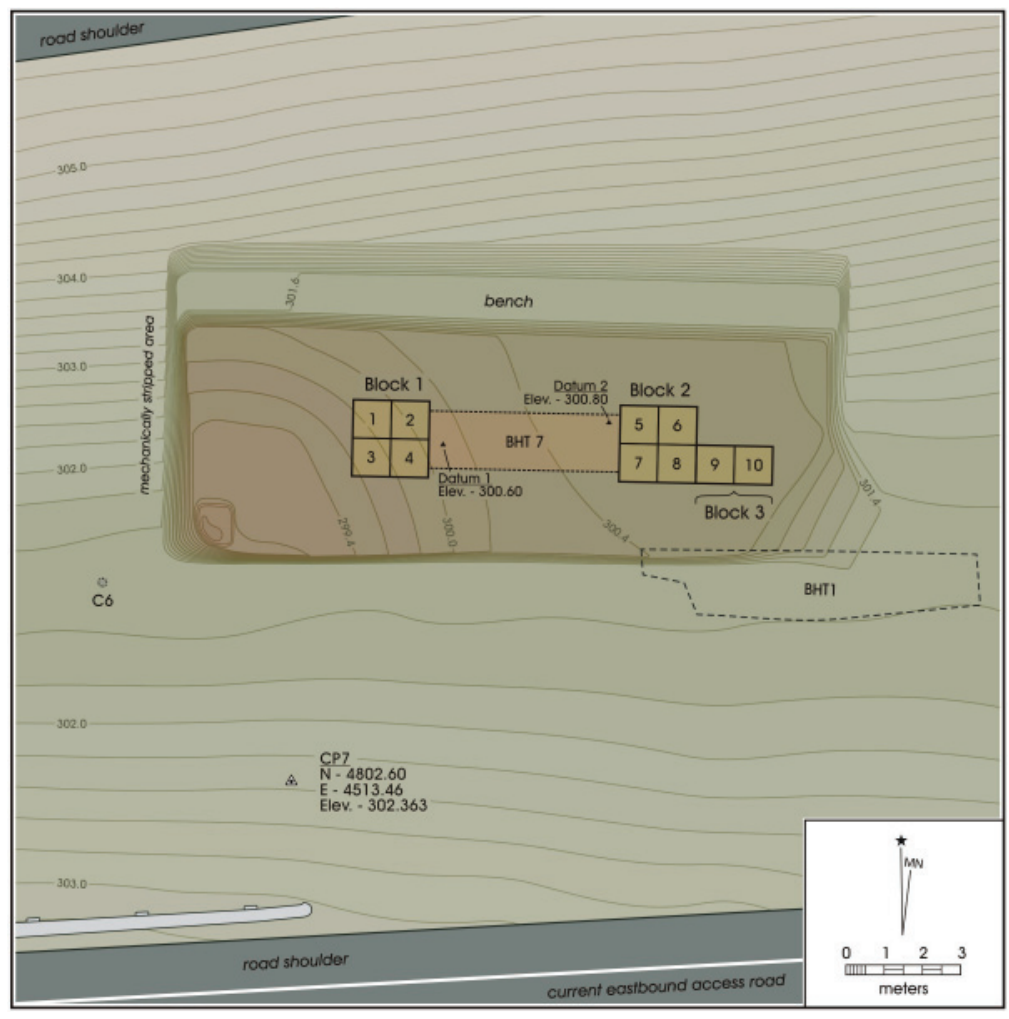

Figure 4-13. Mechanically stripped area with block excavations and Backhoe Trench 7. 


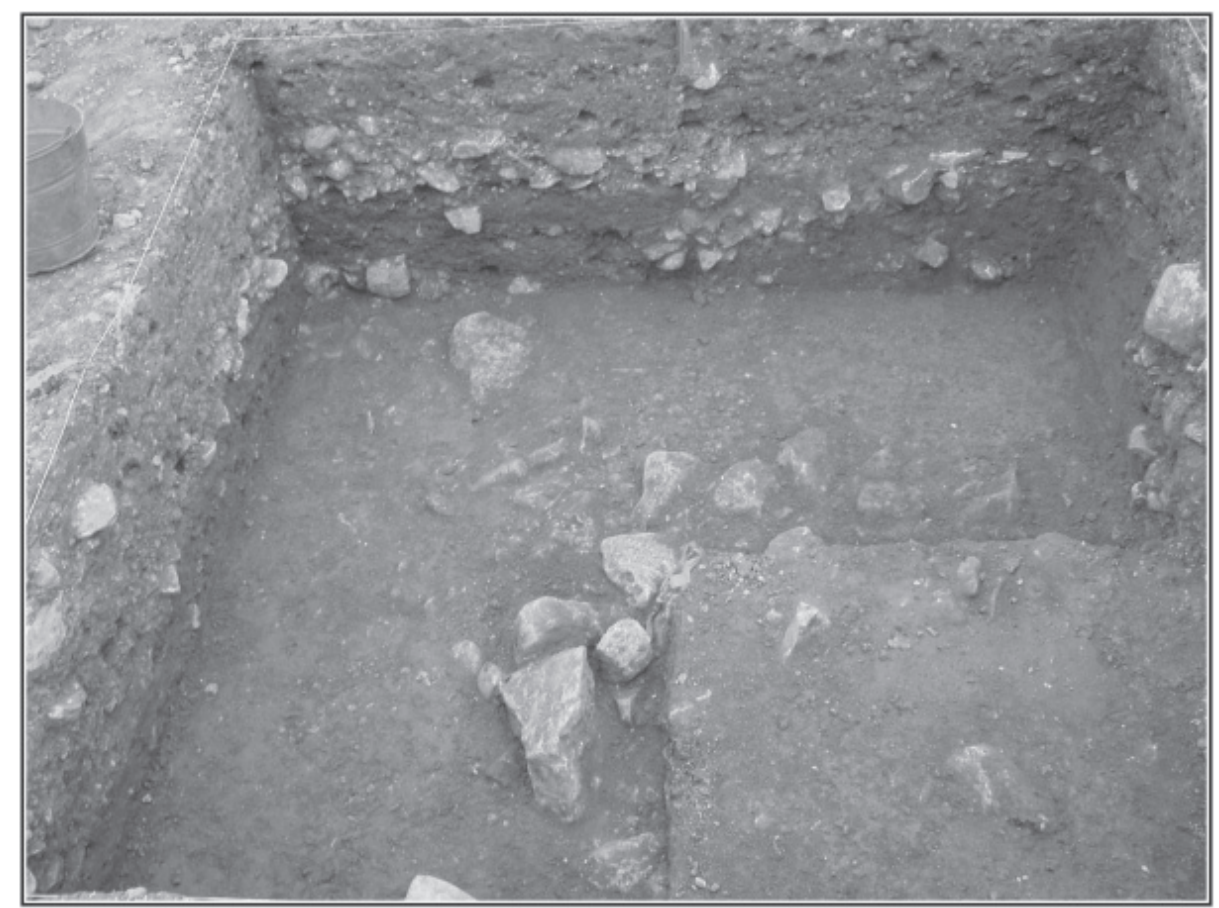

Figure 4-14. Large cobbles in Block 1 excavations (facing north) at $110 \mathrm{cmbs}$.
Cultural material recovered from the block (Table 4-1) included lithic debitage $(\mathrm{n}=230)$, lithic tools $(\mathrm{n}=6)$ and burned rock $(2521.6 \mathrm{~g} ; \mathrm{n}=78)$. Figure 4-16 shows the density of debitage and burned rock per cubic meter $\left(\mathrm{m}^{3}\right)$ by level for Block 1 . As indicated, the highest density of debitage is in Level 2. Thereafter, there is a steady decrease of debitage through Level 5, followed by a small peak in Levels 6 and 7 and a much larger peak in Level 11. Burned rock is most frequent in Level 1 and steady decreases the next two levels. The amount of burned rock is low in the remaining block levels, although two small peaks in density mimic the peaks in debitage. The burned rock in this block was not associated with any features or charcoal or soil stains.

Two diagnostic projectile points were recovered from Block 1. An Early Split-Stemmed dart point was encountered in the southern portion of the block (Unit 3, Level 3) at $60 \mathrm{cmbsl}$. An Angostura dart point (Unit 4, Level 4) was recovered at $64 \mathrm{cmbsl}$. Both points indicate an Early Archaic component at the site associated with the second layer of gravels. Two

Table 4-1. Burned Rock, Debitage, Lithic Tools and Cores Recovered from Block 1

\begin{tabular}{|c|c|c|c|c|}
\hline Level & $\begin{array}{c}\text { Burned } \\
\text { Rock }\end{array}$ & Debitage & $\begin{array}{c}\text { Lithic Tools } \\
\text { and Cores }\end{array}$ & Total \\
\hline 0 & 0 & 0 & 1 & 1 \\
\hline 1 & 37 & 25 & 0 & 62 \\
\hline 2 & 23 & 48 & 1 & 72 \\
\hline 3 & 10 & 20 & 2 & 32 \\
\hline 4 & 0 & 19 & 1 & 20 \\
\hline 5 & 2 & 13 & 1 & 16 \\
\hline 6 & 4 & 21 & 0 & 25 \\
\hline 7 & 1 & 20 & 0 & 21 \\
\hline 8 & 0 & 14 & 0 & 14 \\
\hline 9 & 0 & 3 & 0 & 3 \\
\hline 10 & 0 & 14 & 0 & 14 \\
\hline 11 & 1 & 27 & 0 & 28 \\
\hline 12 & 0 & 2 & 0 & 2 \\
\hline 13 & 0 & 2 & 0 & 2 \\
\hline 14 & 0 & 2 & 0 & 2 \\
\hline Total & 78 & 230 & 6 & 314 \\
\hline
\end{tabular}

Figure 4-15. Profile of the south wall of Test Units 3 and 4 in Block 1. 


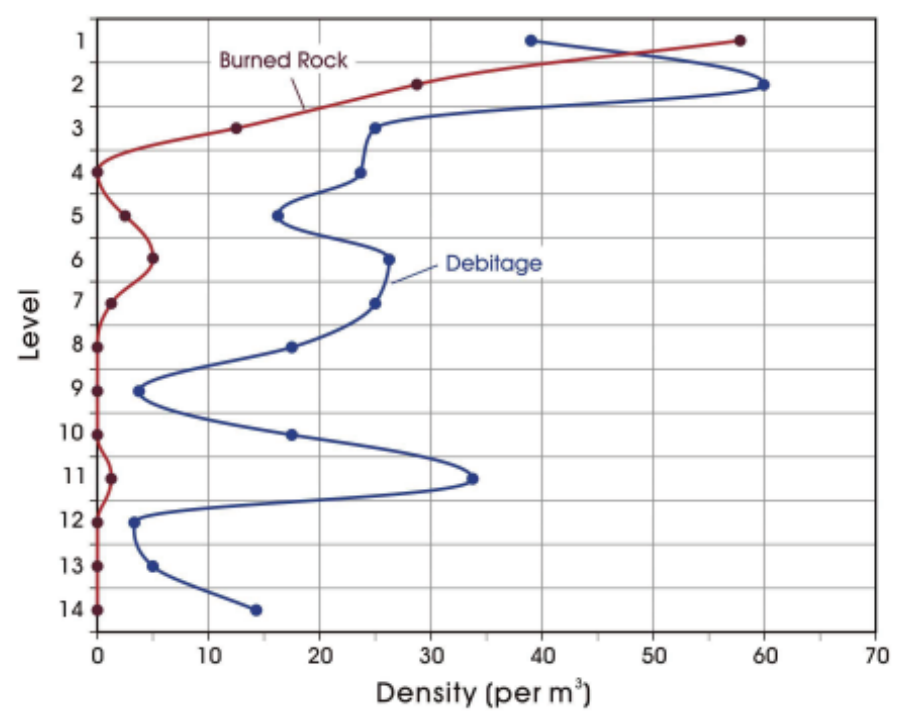

Figure 4-16. Density of artifacts in Block 1.

biface fragments and a core also were among the lithic tools recovered from the Block 1. One biface is also associated with the layer of gravels, while the other biface and core are from the Levels 2 and 3.

\section{Block 2}

This block was $5 \mathrm{~m}$ east of Block 1 (Figure 4-17). Block 2 consisted of Units 5 (N21/E63), 6 (N21/E64), 7 (N20/E63) and 8 (N20/E64). Units 6-8 were excavated to a depth of 15 levels. An additional $16^{\text {th }}$ level was excavated in Unit 5 to confirm that deeper deposits were sterile. The first 15 to 20 centimeters of this block consisted of dense construction fill. Directly below the fill was a gravelly matrix containing lithic debitage and lithic tools. The gravel zone was 40 to 50 $\mathrm{cm}$ thick and was followed by a sandy clay matrix that was nearly void of gravel inclusions (see geoarcheological section). The bulk of cultural material is associated with the thick gravel layer in the upper portion of the block. When looking at the southern profile of the block (Figure 4-18), five stratagraphic zones are distinct. Although the upper portions of the block seem to be dominated by dense gravels, there is a decrease around Level 7, which may represent Suite III deposits (see geoarcheological section). Soil samples were taken from the southern wall of the block for OSL dating.

Cultural material recovered from this block (Table 4-2) included debitage $(\mathrm{n}=193)$, burned rock $(n=28)$ and lithic tools $(n=5)$. Figure 4-19 shows that the highest density of debitage (per cubic meter) and burned rock occurs between Levels 2 and 5 . Although there is a second peak of debitage in Levels 7 and 8, debitage is nearly absent in the lower levels of the block. As the case with Block 1, the burned rock in Block 2 was not clustered nor was it associated with charcoal or soil discolorations that might be indicative of a feature. Five lithic tools were recovered from Block 2, all from within the gravel layer that defines the upper portion of the block. An edgemodified flake was retrieved from Level 2. The distal end of a biface, along with a core and an Early Split Stemmed dart point $(37 \mathrm{cmbd})$ were recovered from Level 3.

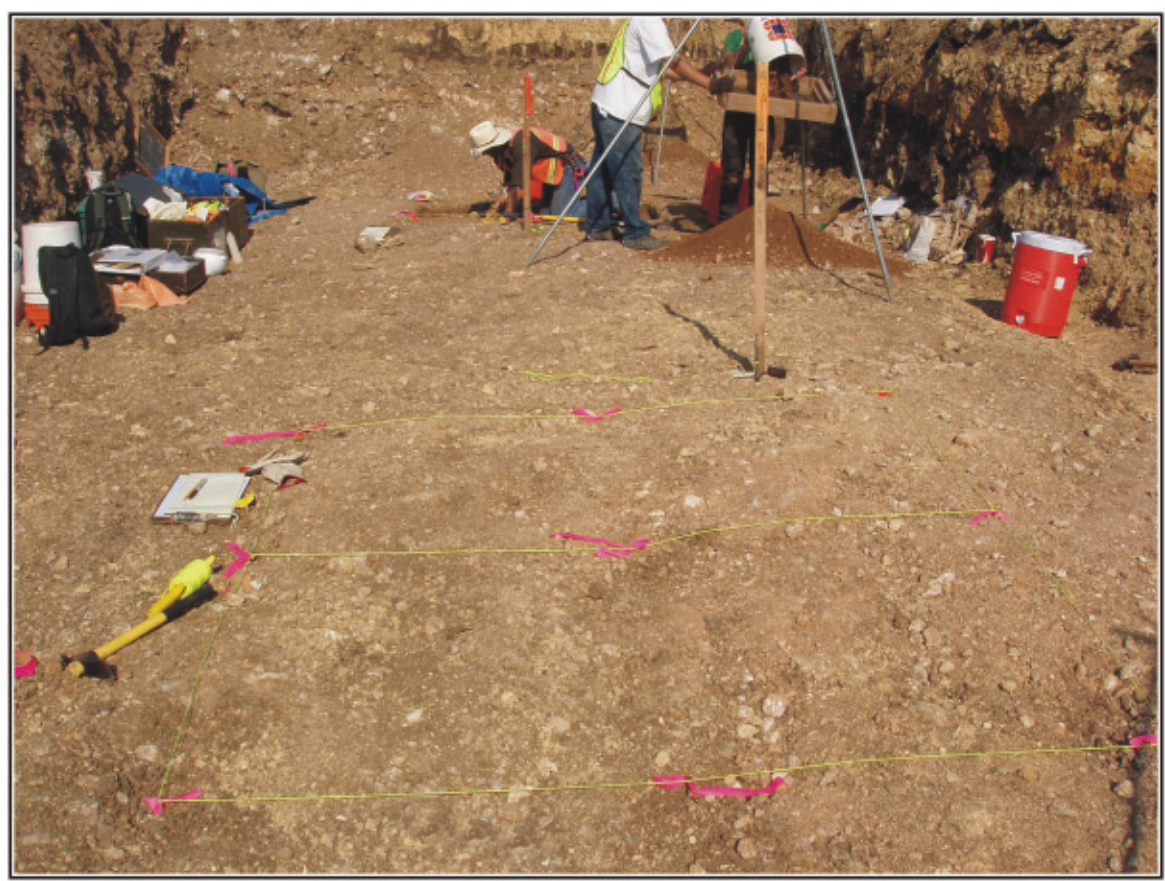

Figure 4-17. Setting up Block 2 excavations (facing west).. 


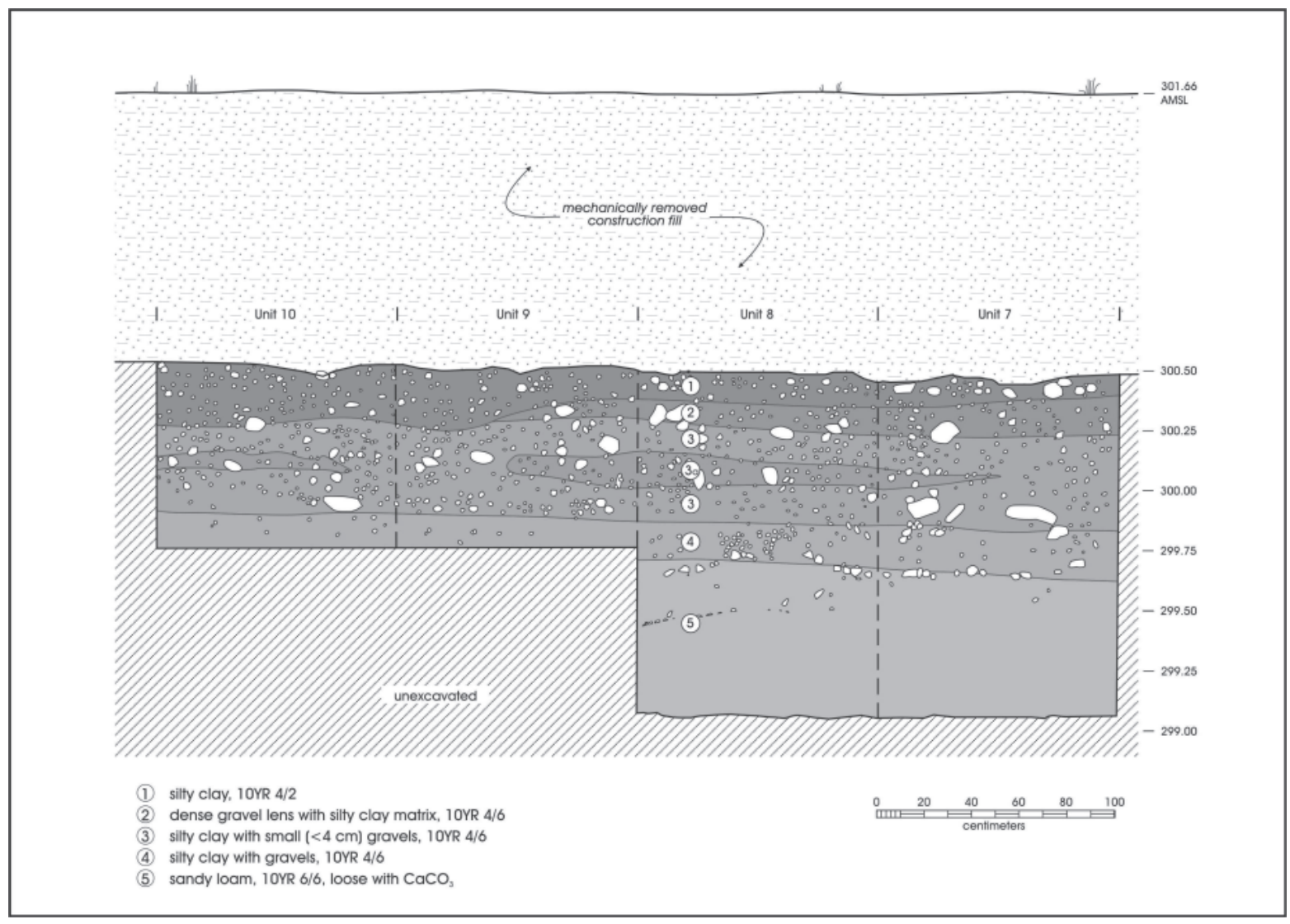

Figure 4-18. Profile of the south wall of Test Units 7, 8, 9, and 10 in Block 2.and Cores Recovered from Block 2.

Table 4-2. Burned Rock, Debitage, Lithic Tools and Cores Recovered from Block 2

\begin{tabular}{|c|c|c|c|c|}
\hline Level & $\begin{array}{c}\text { Burned } \\
\text { Rock }\end{array}$ & Debitage & $\begin{array}{c}\text { Lithic Tools } \\
\text { and Cores }\end{array}$ & Total \\
\hline 1 & 0 & 4 & 0 & 4 \\
\hline 2 & 11 & 20 & 1 & 32 \\
\hline 3 & 6 & 38 & 3 & 47 \\
\hline 4 & 6 & 49 & 1 & 56 \\
\hline 5 & 0 & 43 & 0 & 43 \\
\hline 6 & 0 & 6 & 0 & 6 \\
\hline 7 & 0 & 9 & 0 & 9 \\
\hline 8 & 0 & 10 & 0 & 10 \\
\hline 9 & 0 & 4 & 0 & 4 \\
\hline 10 & 5 & 3 & 0 & 8 \\
\hline 11 & 0 & 1 & 0 & 1 \\
\hline 12 & 0 & 1 & 0 & 1 \\
\hline 13 & 0 & 2 & 0 & 2 \\
\hline 14 & 0 & 2 & 0 & 2 \\
\hline 15 & 0 & 2 & 0 & 2 \\
\hline Total & $\mathbf{2 8}$ & $\mathbf{1 9 4}$ & $\mathbf{5}$ & $\mathbf{2 2 7}$ \\
\hline
\end{tabular}

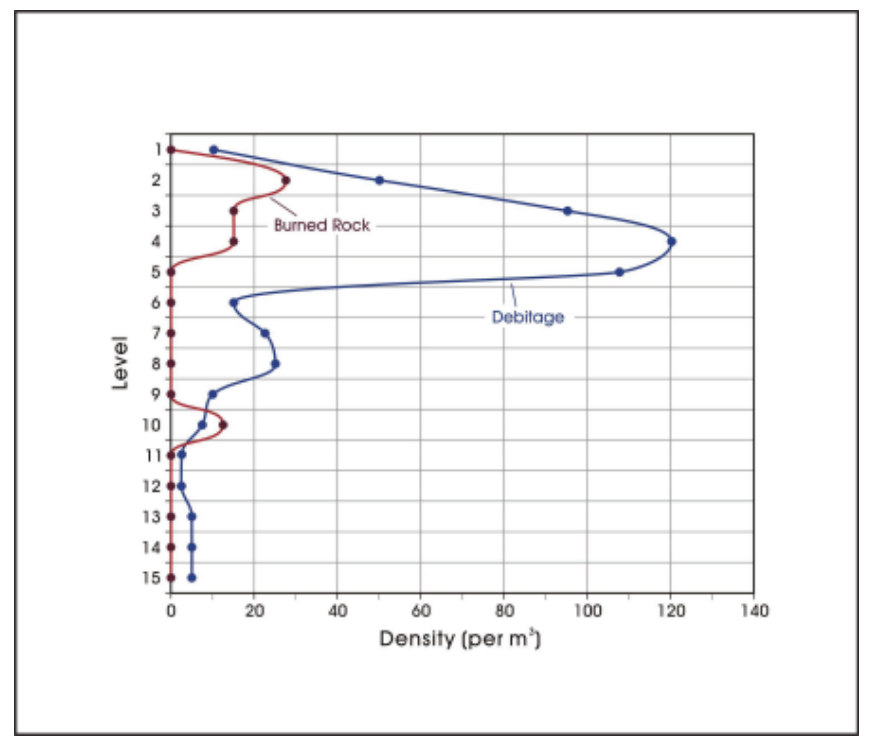

Figure 4-19. Density of artifacts in Block 2.

\section{Block 3}

This 1-x-2-m unit adjoined Block 2 to the southeast (see Figure 4-12). Field operations were interrupted by consecutive rain days and, as a result, inundation of the blocks occurred 
(Figure 4-20). Preliminary inspection of the block profiles (by the geoarcheologist prior to the rains) and the lack of Paleoindian diagnostic material in either block prompted CAR to abandon Block 1 excavations and allocate the remaining levels to opening Block 3 .

The upper $40 \mathrm{~cm}$ of the block was scraped to remove disturbed matrix and to reach the depth of where the Early Split-Stem was recovered in Block 2 (37 cmbd). After the removal of the first $40 \mathrm{~cm}$, the 1-x-2-m block was excavated in five $10 \mathrm{~cm}$ levels, to 90 cmbd. Soils in the block were similar to Block 2 with 10 to 15 $\mathrm{cm}$ of disturbed soil (scraped), followed by a thick gravel layer. A silty loam zone was present in the lower portions of

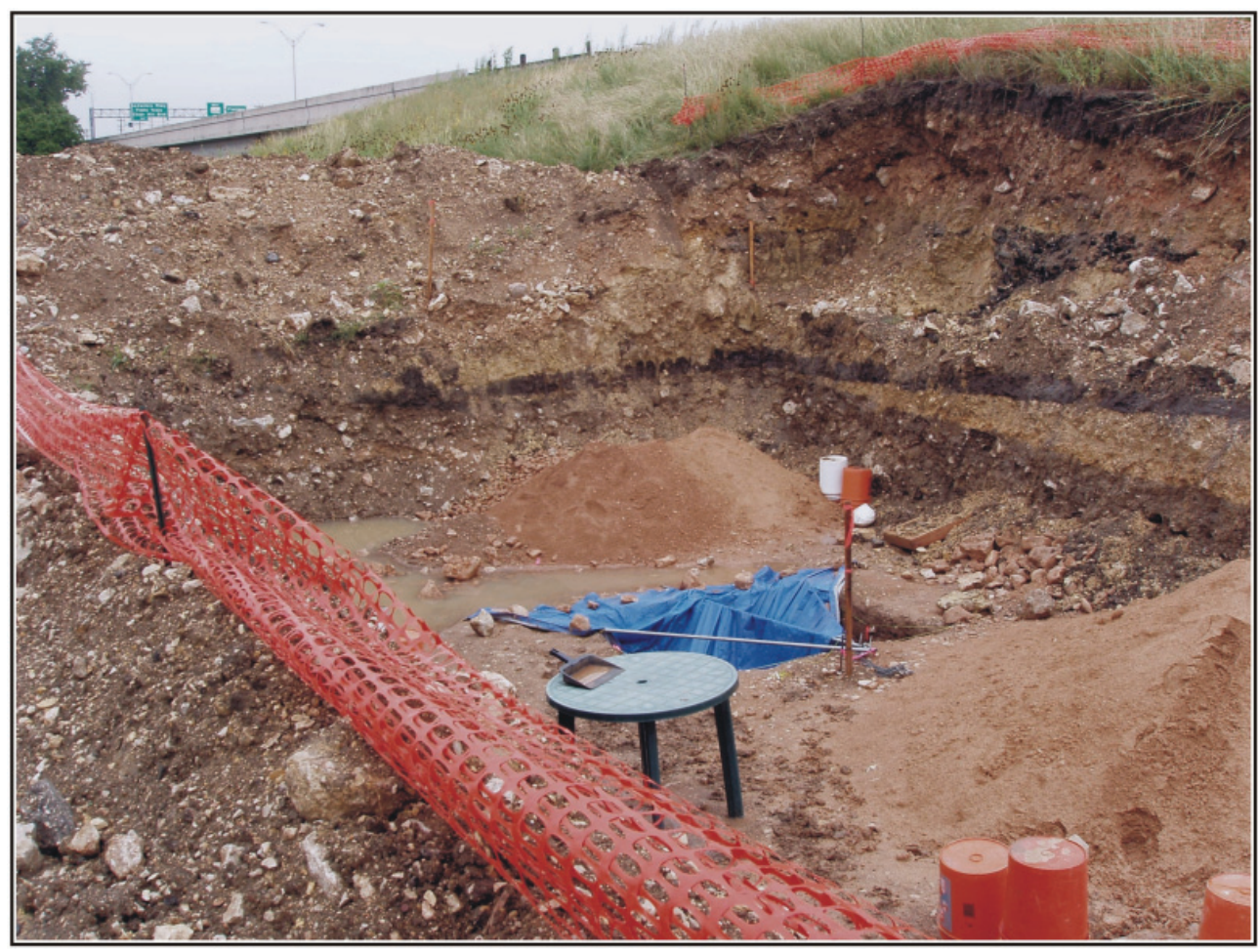

Figure 4-20. Flooding of excavation block during heavy rains. the block $(90 \mathrm{cmbd})$. Debitage $(\mathrm{n}=26)$ and burned rock $(\mathrm{n}=8)$ were scarce in this block (Table 4-3). The majority of debitage was in Level 4 (40-50 cmbd) which steadily decreased and peaked again in Level 5 (80-90 cmbd).

Table 4-3. Burned Rock and Debitage Recovered from Block 3

\begin{tabular}{|c|c|c|c|}
\hline Level & Burned Rock & Debitage & Total \\
\hline 4 & 0 & 4 & 4 \\
\hline 5 & 0 & 4 & 6 \\
\hline 6 & 0 & 3 & 5 \\
\hline 7 & 0 & 4 & 6 \\
\hline 8 & 3 & 6 & 11 \\
\hline 4 & 0 & 5 & 5 \\
\hline Total & $\mathbf{3}$ & $\mathbf{2 6}$ & $\mathbf{3 7}$ \\
\hline
\end{tabular}

As seen in Figure 4-21, there is a peak cultural material in Level 3 and a second peak of debitage and burned rock is evident in Level 8.

\section{Backhoe Trench 7}

As the final task of archeological investigation at 41BX52, Backhoe Trench 7 was excavated between Blocks 1 and 2

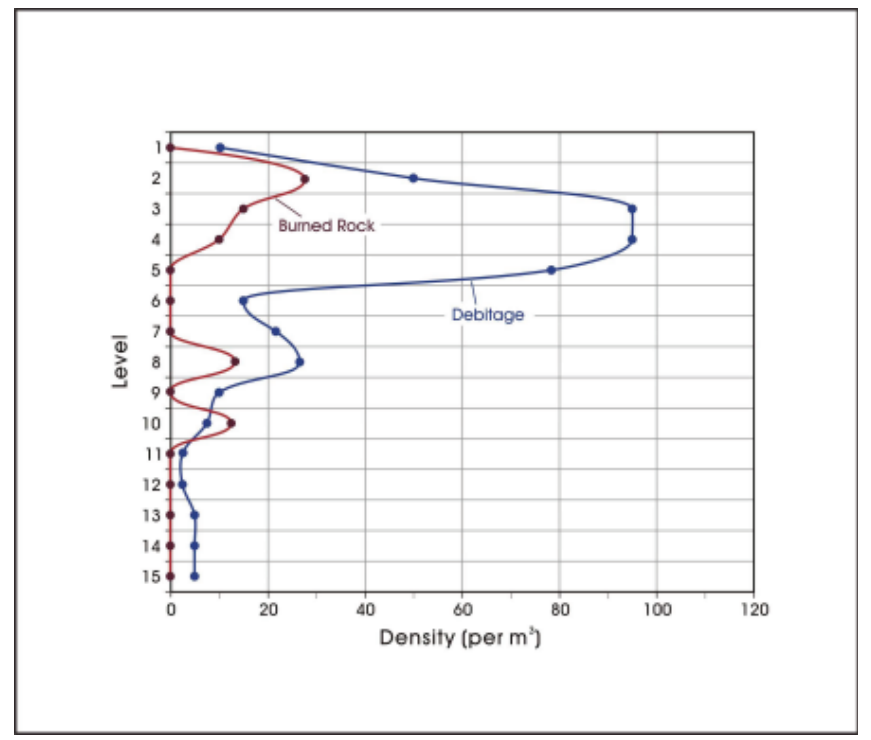

Figure 4-21. Density of artifacts in Blocks 2 and 3.

(see Figure 4-13). This trench connected the two blocks and was $5 \mathrm{~m}$ long and approximately $1.8 \mathrm{~m}$ wide (Figure 4-22). It ranged in depth from $177 \mathrm{cmbd}$ near Block 1 to $160 \mathrm{cmbd}$ near Block 2. The purpose of the trench was to allow for the geomorphic examination and description of the strata spanning both blocks. No artifacts were observed during the excavation of the trench. 


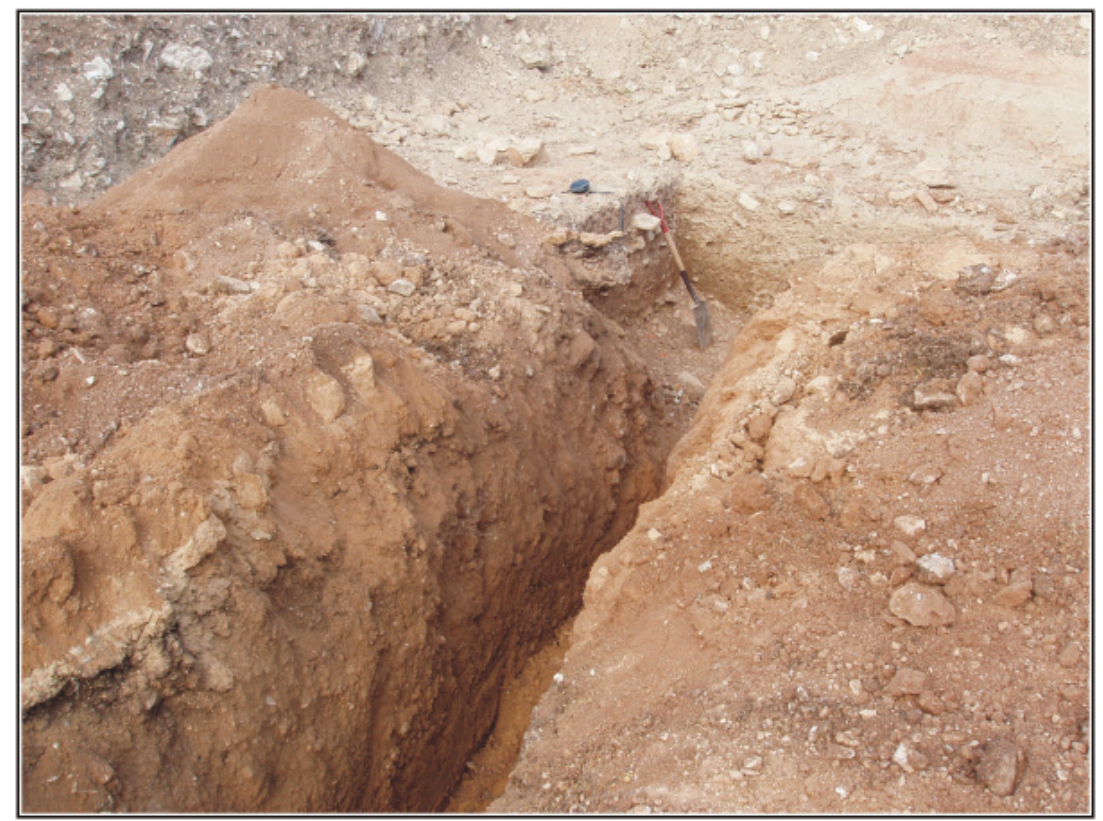

Figure 4-22. Backhoe Trench 7 placed between Blocks 1 and 2.

\section{Results of the Geoarcheological Investigations}

Profiles of the south walls from all three 2-x$2 \mathrm{~m}$ excavation blocks were combined with a sketch profile of the south wall of Backhoe Trench 7 in order to construct a composite image of the deposits directly comparable to the trench profiles reported by Collins et al. in 2003. A total of eight distinct strata were recognized and drawn from the unit walls and Backhoe Trench 7. These deposits are described below (Figure 4-23).

The deepest of our excavation blocks, Block 2, revealed unambiguous Suite II deposits upon termination. The general appearance of these deposits and the presence of small calcium carbonate nodules, is consistent with the micromorphological descriptions of Suite II

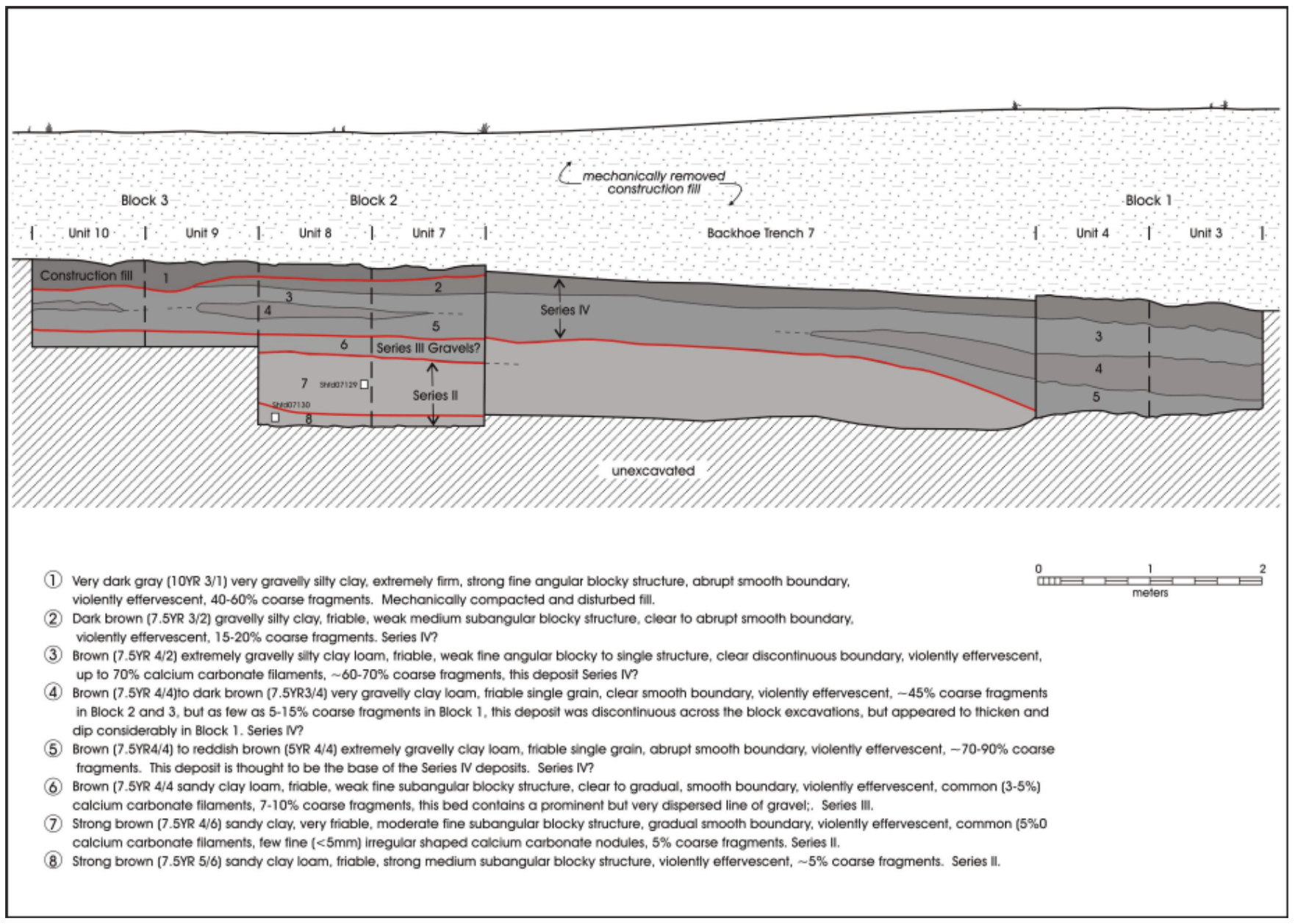

Figure 4-23. Profile showing the south wall of Backhoe Trench 7 in relation to the excavated blocks . 
which were the most detailed lithological descriptions of the site stratigraphy presented in the 41BX52 report (Luchsinger and Collins 2003:63). We collected two OSL samples from the Suite II deposits, one in stratum 8 and another in stratum 7. The Stratum 7 sample was collected as a block rather than in a tube because repeated attempts at sampling this stratum with PVC tubes were thwarted by occasional gravel clasts. Collins and Hudler (2003b) obtained six multiple aliquot OSL ages from monoliths collected at the site that were the basis of the micromorphological study (Luchsinger and Goldberg (2003). Samples from the Suite III deposits (Zone 5b of the monolith stratigraphy) which contained the Paleoindian deposits yielded ages of 11,940 \pm 680 (UIC1078), 11,160 \pm 640 (UIC1081), and 12,690 \pm 700 (UIC1082). Three other ages were obtained from the Suite III deposits situated beneath the Paleoindian occupation. Two of these were from Zone

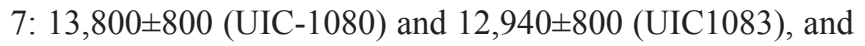
one from Zone 9, 15,770 \pm 890 (UIC1079).

Quartz grains from the two samples were collected from Suite II deposits and were dated at the Sheffield Centre for International Drylands Research using the single grain optically stimulated luminescence (OSL) method (see accompanying report by Bateman (2007) for sample preparation and measurement details). This dating method differs somewhat from the methods employed by Steve Foreman (University of Illinois at Chicago) on the OSL samples from the site that are reported by Collins and Hudler(2003b:71-75). Specifically, Foreman used a multiple aliquot method where the reported ages were determined from aliquots that typically contain around 2000 grains. It has been demonstrated elsewhere that such large aliquot OSL dates from deposits which contain mixed grain ages deposits may yield erroneous OSL ages owing to the effect of averaging (cf. Bateman et al. 2007a; 2007b; Frederick et al. 2006; Wilder et al 2007). The nature of the age error is variable and depends upon the age profile of the grains present in the sample. Fluvial deposits are widely known to present problems for OSL dating owing to poor resetting of the luminescence signal during transportation, but other, largely post-depositional processes familiar to archeologists (specifically bioturbation) may also result in OSL dating irregularities. Given these two potential issues, we chose to use the single grain method to date these samples.
In single grain OSL dating, an OSL age is determined for individual sand grains, and anywhere from 20 to 300 grains may be dated for a single "sample". In this case, Bateman dated 80 sand grains from each sample, and then used the central tendency of the age distribution to calculate the "age" of the population (Appendix A). These two samples yielded single grain OSL ages of 18,300 \pm 920 years BP (Shfd07129) and 18,200 $\pm 1,030$ years BP (Shfd07130). Although the average age of the single grain distributions for both samples is around 18,000 years BP, the distribution of grain ages is abnormally broad, a point Bateman (2007) suggests may be due to post-depositional disturbance. If the single grain paleodoses provided in Bateman (2007) are converted to ages, then the range of grain ages may be plotted (see Figure 4-24) and the distribution examined. Single grain OSL dating of fluvial sediments often reveals polymodal age distributions and in such cases the age of the youngest dominant mode is
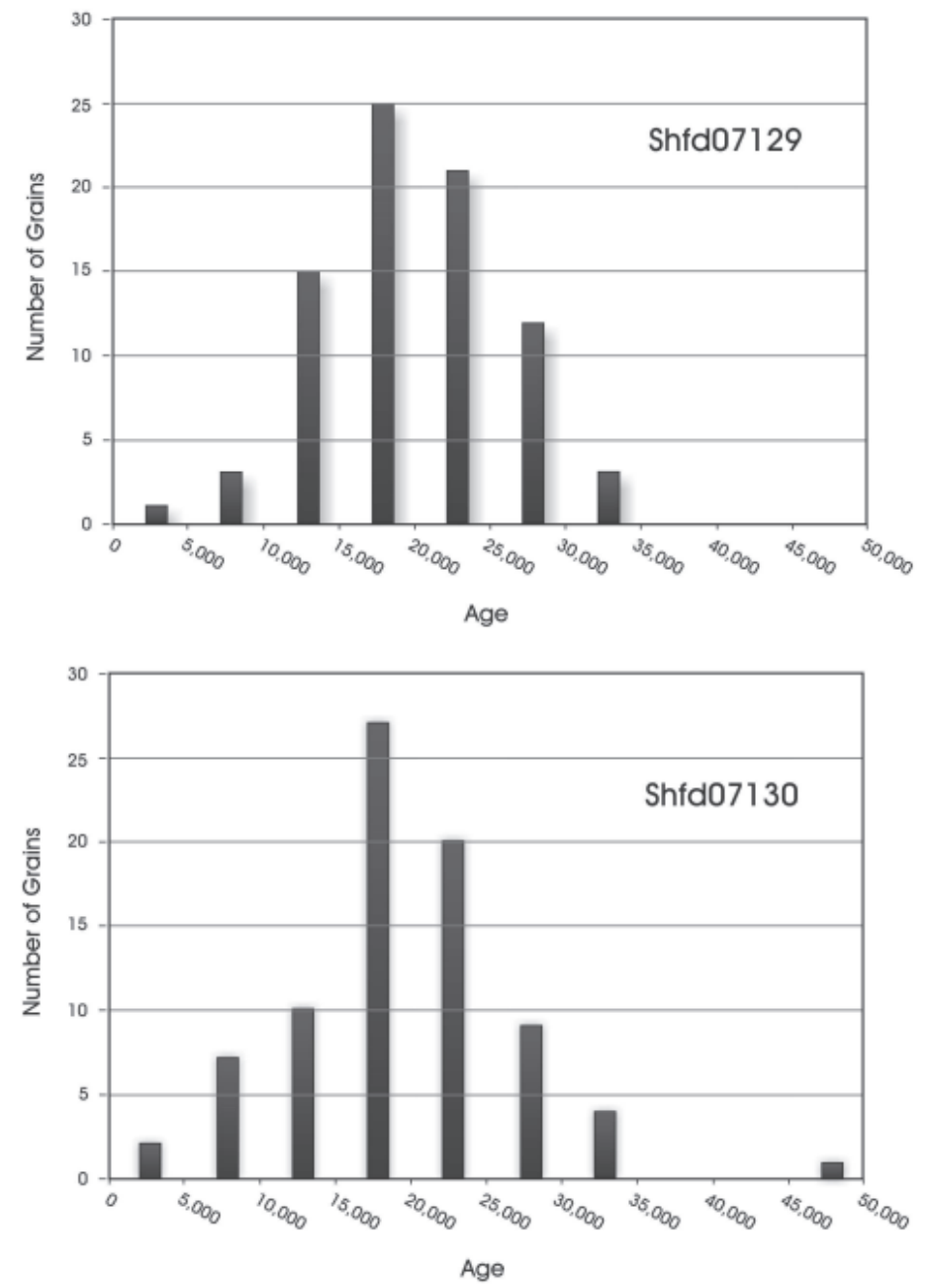

Figure 4-24. Bar chart of grain age. 
often considered to be the time the population was last reset. In the case of these samples, the distribution is unmodal but broadly distributed. It is clear that the sampled deposit lies stratigraphically beneath the Paleoindian component, and for this reason, a reset date in excess of approximately 13,000 years is reasonable (Collins and Hudler (2003b) used the 12,200-12,900 year BP age bracket for the Clovis interval). In each sample $17.5 \%$ of the measured grains (14/80 grains) have been reset since 13,000 years BP, which can only have happened if these grains were exposed to sunlight since they were deposited by the stream. None of the measured grains were zero-dose grains (meaning that they were reset recently, as can occur during sampling or extensive modern bioturbation). This suggests that the distribution is a result of Holocene reworking of the deposit and the most reasonable process through which this may have occurred is through bioturbation.

This raises the question as to whether the cultural material Collins et al. (2003) observed within the Suite II sediments which he interpreted as Pre-Clovis is actually in context or has moved down in the profile by post-depositional processes. These results of the single grain OSL dating suggest that post-depositional disturbance is a very plausible explanation for this observation. The absence of large amounts of gravel within the Stratum II deposits implies that much of this pedoturbation may have been accomplished by small fauna such as insects. The movement of larger materials may have occurred as well.

Resting conformably upon the Suite II sediments was a slightly gravelly deposit which is thought to be a thin remnant of Suite III. This deposit was unconformably overlain by a series of interbedded gravelly and muddy deposits (Strata 2, 3,4 and 5 on Figure 4-23) that are labeled Suite IV. These deposits dipped and thickened to the west. In the east and west walls of Block 1, these deposits clearly filled a gullylike concavity that was oriented downslope to the west.

In general terms, the appearance of the composite profile (Figure 4-23) bears a strong resemblance to some of the long, east-west oriented profiles published by Collins et al. (2003) that show the Suite III deposits, which were relatively flat lying through the area of the block excavations, dipping to the west, toward the modern stream channel (e.g. see Collins et al. 2003, geological profiles 5A, 5B (Figures 4-5 and 4-6), 9 (Figure 4-7) and 2 (Figure 4-8). A strictly literal interpretation of these deposits would identify Strata 2 through 5 on Figure 4-23 as Suite III, but as work progressed we began to form an impression that the deposits exposed here were misidentified by Charles Johnson and subsequently by Collins when he performed the arduous task of reconstructing the site stratigraphy from Johnson's notes. The absence of detailed notes on the colors and general appearance of the deposits from the original excavation clearly complicates correlation with Collins et al. (2003). As the excavations progressed, we formed the opinion that the Suite II and III deposits were of fairly similar color. In the area of our block excavations the Suite III deposits had been truncated by erosion and a younger body of alluvium consisting of alternating gravel and muddy sediment was deposited upon it. This interpretation is depicted on Figure 4-23, with bold dotted lines separating what are thought to be the major stratigraphic units.

This younger body of alluvium has a more prominent brown color (as opposed to a strong brown color) than the Suite II and presumed Suite III deposits. For the sake of consistency, we have identified these deposits on Figure 4-23 as Suite IV but this must be qualified. Collins et al. (2003) identified the next younger alluvial deposit as Suite IV, which was thought to "have accrued over most of the Holocene". Like all of the other deposits, a dearth of descriptive detail exists for Suite IV. The deposits identified as Suite IV on Figure 4-23 are probably of much more limited age than identified by Collins et al. (2003), and probably are of Early-Middle Holocene age. The only temporally diagnostic cultural material obtained from the block excavations were from the middle Block 1 (base of Stratum 3) and were of Early Archaic age, which supports this general interpretation.

Because these deposits were suspected to be of Early Holocene rather than late Pleistocene age, a series of bulk samples were collected from Block 1 in order to test this hypothesis. We intended to radiocarbon date both bulk organic matter as well as snail shells from Strata 3, 4 and 5. We believe that if our interpretation is correct and some of the westward dipping deposits situated to the west of the original block excavation shown in the Collins et al. (2003) report as Suite III are actually a younger alluvial deposit, then this is important information which should be documented by radiocarbon dating.

In retrospect we consider it potentially significant that the block excavations reported by Collins et al. (2003) generally did not extend eastward into the area where the long profile drawings showed an expansion of the Suite III sediments containing the Clovis and Folsom occupations. This area, if their stratigraphic drawings were correct, should have had better stratigraphic preservation of the target occupations. However, our recovery of Early Archaic materials almost half way through these deposits suggests that these sediments are not Suite III but rather an Early Holocene alluvial deposit. This would explain why the original excavation did not extend into this area. 


\section{Chapter 5: Lithic Analysis}

During the block excavations at 41BX52 11 lithic tools and cores and 445 pieces of lithic debitage were recovered. The previous chapter discussed patterns noted in the vertical distribution of debitage. This section discusses the results of the debitage and tool analysis.

\section{Debitage}

Debitage $(\mathrm{n}=445)$ was the most frequent artifact type recovered from testing at 41BX52. For each specimen four attributes were noted: weight, maximum dimension, the presence or absence of patina and the percentage of cortex. A fair amount of the debitage recovered was coated with calcium carbonate residues. Several specimens were soaked in white vinegar to dissolve the residues and allow for better examination of the specimens. This section discusses the results of the debitage analysis and is organized by attribute.

\section{Size}

The weight and maximum dimension of every specimen was measured. Debitage size should be indicative of reduction processes. The smaller the debitage the closer to completion the end product is assumed to be. The mean weight of the debitage was $5.63 \mathrm{~g}$. the average maximum dimension for the entire assemblage was $14.84 \mathrm{~mm}$. To determine whether the debitage specimens from Suite II were redeposited from higher zones, we compated the size of debitage by depositional zone. Figure 5-1 indicates a significant size difference between specimens in Suites II and III. Debitage from Suite II is smaller than that found in Suites III and IV. Using SPSS 15.0, we also performed the Mann-Whitney Test (nonparametric test for paired data, Shennan 1990:61-62) and the average rank for the maximum dimension of Suite II debitage is $13.47 \mathrm{~mm}$. This average rank is smaller than Suite III debitage (20.32 $\mathrm{mm})$. The Mann-Whitney $U$ is 79.50 . The observed two-tailed significance level is .041, concluding that the maximum dimension of debitage in Suite II is significantly smaller than in Suite III. This analysis suggests there is evidence of size sorting with smaller pieces probably moving their way down through soil deposits. Therefore, the debitage recovered from Suite II deposits were not within a primary context.

\section{Patina}

The presence and absence of patina was recorded for each specimen. Although the absence of patination does not indicate recent deposits, the presence of patina is typically associated with older material (Frederick et al. 1994). Ninety percent of the debitage assemblage was patinated. In the Early Archaic deposits (Suite IV), $89 \%$ of the specimens were recorded as having patina. Though few $(n=17)$, all of the debitage from Suite III contained patina, as did the Suite II specimens $(\mathrm{n}=16)$.

\section{Cortex}

As with size, the amount of cortex on a specimen can be related to reduction processes (Andrefsky 1998). It is expected that the amount of cortex should be less on late reduction specimens and greater on early reduction pieces.

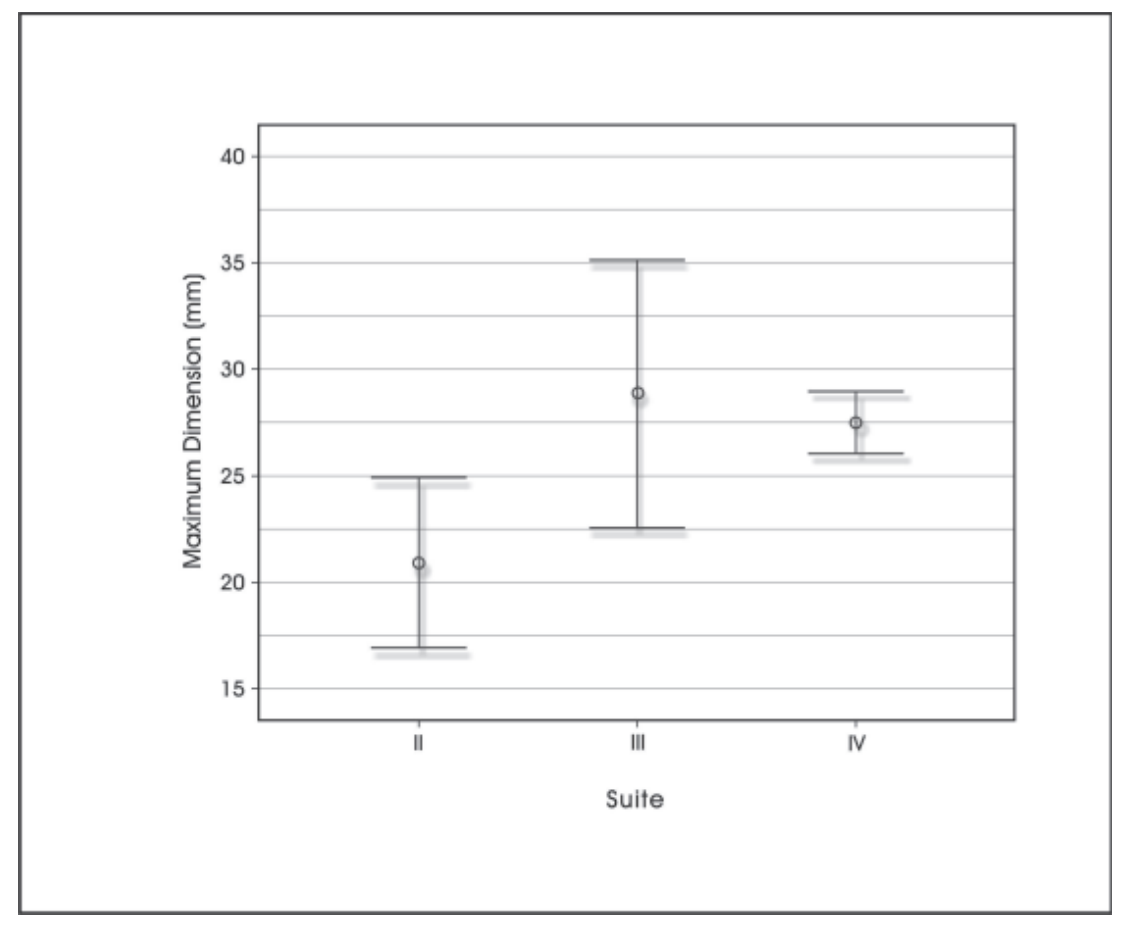

Figure 5-1. Error bar graph depicting the average maximum dimension $(95 \%$ confidence level) of debitage by suites. 
Cortex was measured on each specimen by percentage. Each specimen was noted as having $0 \%, 1-25 \%, 26-50 \%, 51-75 \%$ or $76-100 \%$. Cortex categories were placed into three groups $(0 \%, 1-50 \%$ and $51-100 \%)$. Eighty-three percent of the assemblage consisted of tertiary flakes $(0 \%)$, followed by $10 \%$ secondary flakes (1-50\%). Primary flakes (51-100\%) only made up $6 \%$ of the assemblage. Figure 5-2 suggests that the smaller the debitage, the less likely that it retains cortex. Table 5-1 displays the cortex percentage categories by suite and adjusted residuals. Adjusted residuals provide information on the contribution of each individual cell to the overall contingency table. Adjusted residual values exceeding an absolute value of 1.96 suggest that the cell differences are statistically significant at a .05 level of probability. As seen in Table 5-1, specimens without cortex are underrepresented in Suite IV, while specimens with $1-50 \%$ cortex are over represented in the Suite.

Table 5-1. Crosstabulation of Cortex Percentage by Soil Suite

\begin{tabular}{|l|l|c|c|c|c|}
\hline Cortex \% & Soil Suite & $\mathbf{2}$ & $\mathbf{3}$ & $\mathbf{4}$ & Total \\
\hline $\mathbf{0 \%}$ & Count & 16 & 17 & 338 & 371 \\
\hline & $\begin{array}{l}\text { Adjusted } \\
\text { Residual }\end{array}$ & 1.8 & $\mathbf{1 . 9}$ & $\mathbf{- 2 . 7}$ & \\
\hline $\mathbf{1 - 5 0 \%}$ & Count & 0 & 0 & 46 & 46 \\
\hline & $\begin{array}{l}\text { Adjusted } \\
\text { Residual }\end{array}$ & -1.4 & -1.4 & $\mathbf{2}$ & \\
\hline $\mathbf{5 1 - 1 0 0 \%}$ & Count & 0 & 0 & 28 & 28 \\
\hline & $\begin{array}{l}\text { Adjusted } \\
\text { Residual }\end{array}$ & -1.1 & -1.1 & 1.5 & \\
\hline Total & Count & 16 & 17 & 412 & 445 \\
\hline
\end{tabular}

\section{Lithic Tools and Cores}

Eleven lithic tools and cores were recovered from excavations. Six of the tools and cores were from Block 1, while the remaining were from Block 2. They consisted of bifaces $(n=4)$, projectile points $(n=4)$, edge-modified flakes $(n=1)$ and cores $(n=2$; Figure 5-3). Four projectile points were found during the 41BX52 excavations (Figure 5-3 a-d). Three of the points were from Block 1, while only one came from Block 2. A Late Prehistoric Perdiz point (Figure 5-3 d) was recovered from the surface adjacent to Block 1, percentage.

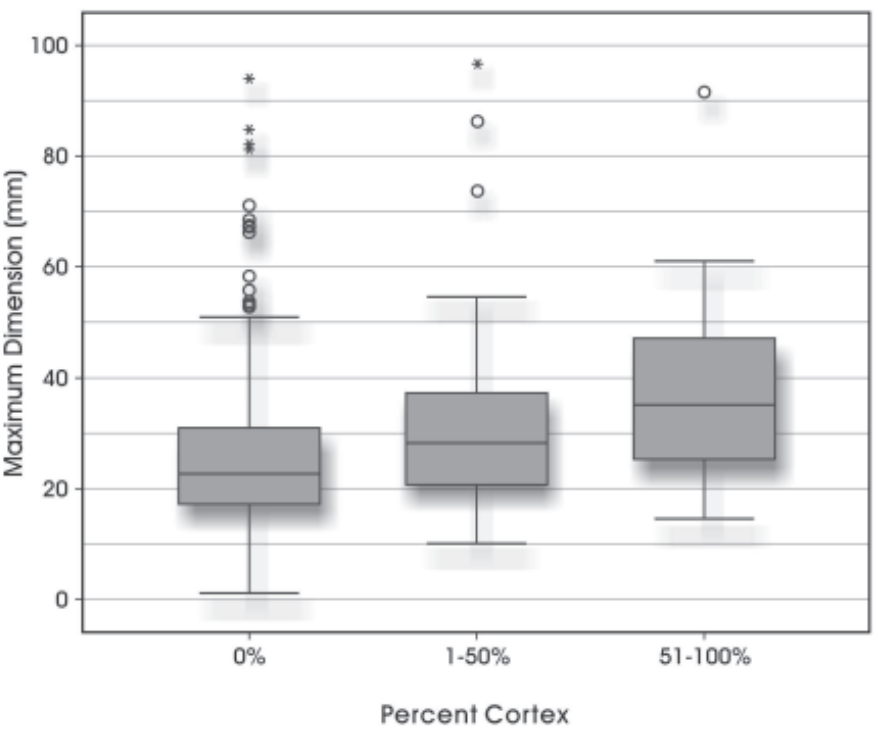

Figure 5-2. Box plot showing the average maximum dimension of debitage and cortex

presumably from disturbed soils that were removed from atop the blocks. It measured $27 \mathrm{~mm}$ in length and only 11 $\mathrm{mm}$ in width. The second projectile point from Block 1 is an Early Split Stemmed (similar to a Bandy form) from $60 \mathrm{cmbd}$ (Figure 5-3 b). It is broken at its distal end and measures $41 \mathrm{~mm}$ long by $26 \mathrm{~mm}$ wide. The third point from the Block was a Angostura type (Figure 5-3 a), encountered at $64 \mathrm{cmbd}$. Its dimensions are $74.08 \mathrm{~mm}$ long by $24 \mathrm{~mm}$ wide. Both the Early Split Stemmed and Angostura date to the Early Archaic period. Only one projectile point was encountered in Block 2, from $38 \mathrm{cmbd}$. It is the proximal portion of an Early SplitStem (similar to a Bandy form) as seen in Block 1 (Figure 5-3 c). It measures $31 \mathrm{~mm}$ long by $27 \mathrm{~mm}$ wide. All of the points exhibit signs of patination.

All four bifaces were broken (Figure 5-3 e-h), three at the proximal end and one at the distal end. All of the specimens were covered with patina and two were heat treated. The specimens appeared to be late stage bifaces. Unfortunately, the broken state of the bifaces hindered obtaining a width to thickness ratio.

Multi-directional cores were recovered from both blocks (Figure 5-3 i-j). The core from Block 1 (Figure 5-3 i) was exhausted and small $(75 \mathrm{~mm} \times 49 \mathrm{~mm})$ and it was heavily coated with patina. The core from Block 2 (Figure 5-3 j) was also heavily patinated and measured $117 \mathrm{~mm}$ long by $81 \mathrm{~mm}$ 


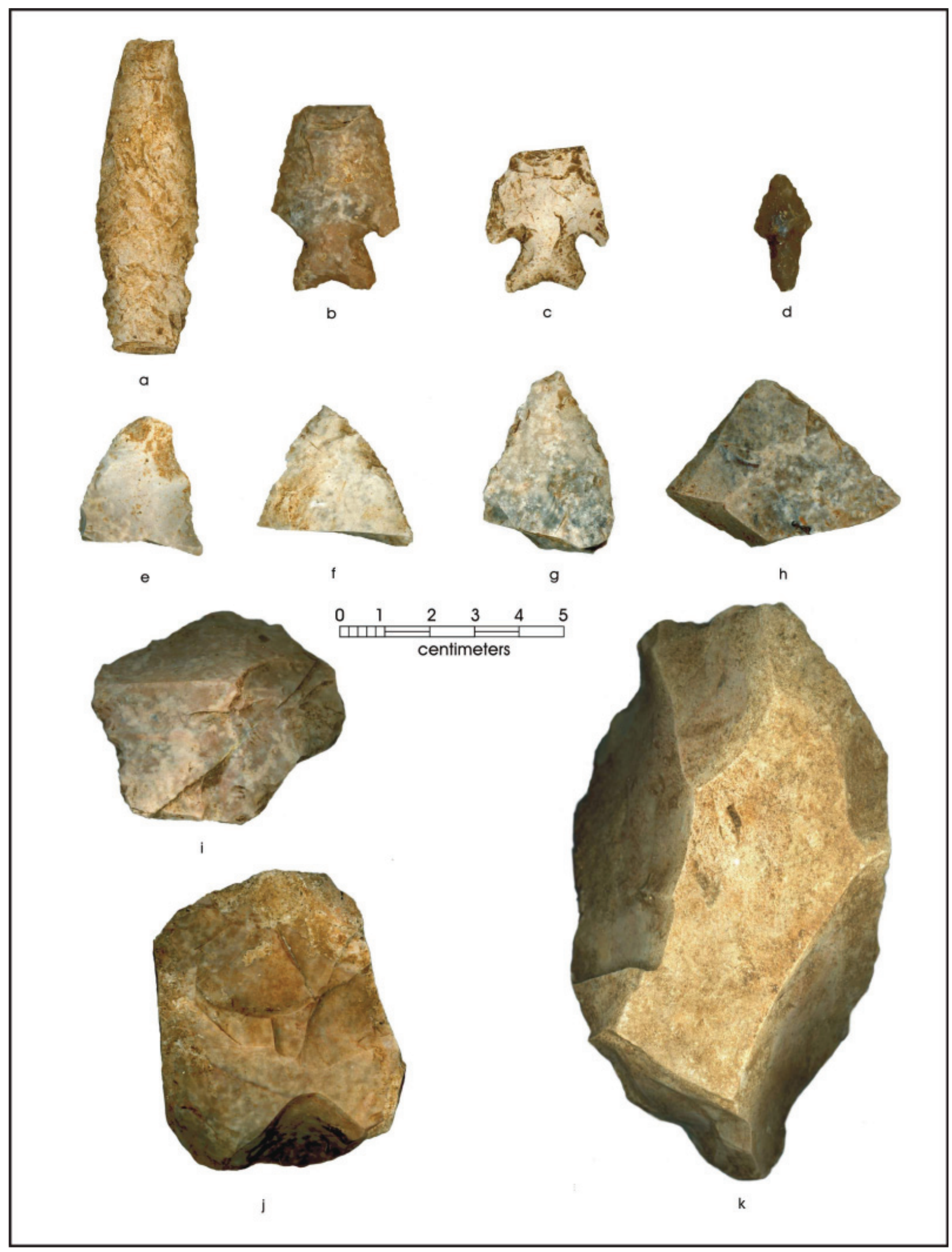

Figure 5-3. Lithic tools from 41 BX52 block excavations a) Angostura b,c) Early Split Stemmed, d) Perdiz, e-h)bifaces, i,j) core, $k$ ) edge-modified flake. 
wide. Lastly, one edge-modified tool was recovered from Level 2 of Block 2 (Figure 5-3 k). It was produced from a complete flake ( $57 \mathrm{~mm}$ by $50 \mathrm{~mm}$ ). This tool was also heavily patinated.

In summary, the results of the lithic analysis indicate that a majority of the debitage consists of tertiary flakes. Moreover, more than half of the assemblage is heavily patinated.
Although the average size of the debitage is $14.84 \mathrm{~mm}$, the analysis found that Suite II contained significantly smaller specimens than Suite III. Therefore, it is highly probable that the debitage from Suite II could have worked its way down to this deposit rather than representing an earlier occupation of the site. Of the eleven lithic tools, only four were temporally diagnostic. Three points date to the Early Archaic and one is a Late Prehistoric Perdiz point found on surface. 


\section{Chapter 6: Conclusions and Recommendations}

The CAR staff performed archeological testing at 41BX52 between November 2006 and June 2007. Investigations included coring, backhoe trenching and manual block excavations. The purpose of archeological testing was to determine the depth of construction fill and the presence, location and, if possible, condition, of any remnant archeological deposits. Proposed improvements along Loop 1604 include bridge bents that will be constructed east of Leon Creek and west of the IH-10/Loop 1604 interchange overpass. Impacts associated with proposed improvements will occur within the boundaries and in the immediate vicinity of 41BX52.

Proposed improvements along Loop 1604 will include bridge bents that will be constructed east of Leon Creek and west of the IH-10/Loop 1604 interchange overpass. Twenty three bridge bents are proposed. Bridge bents are anticipated to penetrate to $9.5 \mathrm{~m}$ below surface adjacent to the creek. In addition to the bridge bents, a Water Pollution Abatement Plan (WPAP) basin will be placed within the median on the south side of the project area. The WPAP basin will measure approximately $20-\mathrm{x}-14-\mathrm{m}$ in size and will be approximately $6 \mathrm{~m}$ deep.

Coring efforts could not penetrate the massive and compact road fill. Moreover, backhoe trenching could not reach beneath the thick fill located within the northern median near Leon Creek due to the limitation of the equipment. However, during backhoe trenching Suite II deposits, identified during the original 1979 and 1980 excavations of the site, were identified in the western portion of the site. Based on these findings, along with the 1979 and 1980 information, it was anticipated that intact Suite III deposits (associated with the Paleoindian component) may be present and block excavations were conducted in this area.

Two block excavations encountered Early Archaic diagnostic materials situated in Early-Middle Holocene, Suite IV, soils. Although, Early Archaic diagnositics were present at the site, they were within a high engery deposit that appeared to be transported into the site. In Block 2, Suite IV soils were stratigraphy positioned above Suite III (Paleoindian) soils though Paleoindian diagnostics were never encountered during investigations.

Confirmed by OSL dates, Suite II soils were present beneath Suite III deposits in Block 2. Although, debitage was retrieved from Suite II deposits, the results of statistical analyses suggest that the small sample is size sorted and the specimens may drive from Suite III. In addition, OSL dates indicate that Suite II deposits date to around 18,000 years BP. Moreover, OSL dating suggests that Suite II deposits may have undergone post-depositional disturbances. While Collins et al. (2003) raised the intriguing possibility that Suite II materials may be pre-Clovis in age, the two lines of inquiry pursued here suggest that the cultural materials from Suite II deposits likely originated from overlying suites.

Overall, the archeological investigations conducted at 41BX52 in have helped clarify issues related to the stratigraphy and chronology of this portion of the site. Moreover, the CAR investigation uncovered no cultural materials of Paleoindian age that would contribute to the NRHP eligibility of the site. The Early Archaic materials identified during the investigations are sparse and in our opionio the CAR work has exhausted their research potential. Therefore, CAR does not recommend further work within the project area where Loop 1604 improvements will take place. 



\section{References Cited}

Bateman, M.D.

2007 Quartz optical dating report, Site 41BX52, Texas, USA. Sheffield Centre for International Drylands Research, Sheffield, England.

Bateman, M.D., Boulter, C.H., Carr, A.S., Frederick, C.D., Peter, D., and Wilder, M.

2007aDetecting post-depositional sediment disturbance in sandy deposits using optical luminescence. Quaternary Geochronology 2:57-64.

2007bPreserving the palaeoenvironmental record in Drylands: Bioturbation and its significance for luminescence-derived chronologies. Sedimentary Geology 195(1-2):5-19.

Bement, L.C.

1991 The Thunder Valley Burial Cache: Group Investment in a Central Texas Sinkhole Cemetery. Plains Anthropologist 36(135):97-109.

Black, S.L.

1989a Central Texas Plateau Prairie. In From the Gulf Coast to the Rio Grande: Human Adaptations in Central, South and Lower Pecos Texas. by T. R. Hester, S. L. Black, D. G. Steele, B. W. Olive, A. A. Fox, K. J. Reinhard and L. C. Bement, pp. 17-38. Research Series No. 33. Arkansas Archeological Survey, Fayetteville.

1989bEnvironmental Setting. In From the Gulf Coast to the Rio Grande: Human Adaptations in Central, South and Lower Pecos Texas. by T. R. Hester, S. L. Black, D. G. Steele, B. W. Olive, A. A. Fox, K. J. Reinhard and L. C. Bement, pp. 17-38. Research Series No. 33. Arkansas Archeological Survey, Fayetteville.

2003 Archaic Pavo Real. In Pavo Real (41BX52): A Paleoindian and Archaic Camp and Work-Shop on the Balcones Escarpment, South-Central Texas. by Michael B. Collins, Dale B. Hudler and Stephen L. Black, pp. 39-57. Studies in Archeology 41. Texas Archeological Research Laboratory, The University of Texas at Austin.

Black, S. L. and D. G. Creel

1997 The Central Texas Burned Rock Midden Reconsidered. In Hot Rock Cooking on the Greater Edwards Plateau: Four Burned Rock Midden Sites in West Central Texas, by Steve L. Black, Linda W. Ellis, Darrell G. Creel, and Glenn T. Goode, pp. 269-305. Studies in Archeology 2. Texas Archeological Research Laboratory, The University of Texas at Austin.

Bousman, B.C.

1991 Paleoenironments. In Excavations at the Bottoms, Rena Branch, and Moccas in Springs Sites, Jewett Mine Project, Freestone and Leon Counties, Texas. Report Investigations 82:21-35, Prewitt and Associates Inc.

1998 Paleoenvironmental Change in Central Texas: The Palynological Evidence. Plains Anthropologist 43 (164):201-219

Bousman, B.C., B.W. Baker and A.C. Kerr

2004 Paleoindian Archeology in Texas. In The Prehistory of Texas, edited by Timothy K. Perttula, pp. 15-97. Texas A \& M University Press, College Station. 
Brune, G.

1981 Springs of Texas. Branch-Smith, Ft. Worth.

Collins, M.B.

1995 Forty Years of Archaeology in Texas. Bulletin of the Texas Archeological Society 66:361-400, The University of Texas at Austin.

2003 Quaternary Geology of the Pavo Real Locality. In Pavo Real (41BX52): A Paleoindian and Archaic Camp and WorkShop on the Balcones Escarpment, South-Central Texas by M. B. Collins, D. B. Hudler and S. L. Black, pp. 39-57. Studies in Archeology 41. Texas Archeological Research Laboratory.

2004 Archeology in Central Texas. In The Prehistory of Texas, edited by T. K. Perttula, pp.101-126. Texas A\&M University Press, College Station.

Collins, M.B., D. Hudler and S.L. Black

2003 Pavo Real (41BX52): A Paleoindian and Archaic Camp and Workshop on the Balcones Escarpment, South-Central Texas. Studies in Archeology 41. Texas Archeological Research Laboratory, The University of Texas at Austin.

Collins, M. B. and D.B. Hudler

2003a Site Setting, Environment and Description. In Pavo Real (41BX52): A Paleoindian and Archaic Camp and Work-Shop on the Balcones Escarpment, South-Central Texas by M. B. Collins, D. B. Hudler and S. L. Black, pp. 23-38. Studies in Archeology 41. Texas Archeological Research Laboratory, The University of Texas at Austin.

2003b Dating the Paleoindian Component at Pavo Real, OSL and ${ }^{14} \mathrm{C}$ Results. In Pavo Real (41BX52): A Paleoindian and Archaic Camp and Workshop on the Balcones Escarpment, South Central Texas, by M. B. Collins, D. B. Hudler and S. L. Black, pp. 71-75. Studies in Archaeology 41, Texas Archeological Research Lab, The University of Texas at Austin.

Collins, M.B., J. Guy and S.W. Dail

1998 The Archaic Period, 8800 to 1300 B. P. In Wilson-Leonard: An 11,000-year Archaeological Record of HunterGatherers in Central Texas. Volume I: Introduction, Background and Syntheses, edited by Michael B. Collins. Studies in Archaeology 31. Texas Archeological Research Laboratory, The University of Texas at Austin.

Ferring, C.R.

2001 The Archaeology and Paleoecology of the Aubrey Clovis Site (41DN479) Denton County, Texas. Center for Environmental Archaeology. Department of Geography, University of North Texas, Dayton.

Fox, A.A., and D.E. Fox

1967 The Classen Rockshelter, 41BX23. Manuscript on file, Center for Archaeological Research, The University of Texas at San Antonio.

Frederick, C.D., M.D. Glascock, H. Neff, and C.M. Stevenson

1994 Evaluation of Chert Patination as a Dating Technique: A Case Study from Fort Hood, Texas. Mariah Associates, Austin Texas. Research Report No. 32. Archaeological Resource Management Series, United States Army, Fort Hood. 
Frederick, C.D., Bateman, M.D. and Carr, A.

2006 Evaluating the formation processes of sandy sites in flat landscapes at Avon Park Air Force Range. In Archaeological and Geomorphological Investigations on the Avon Park Air Force Range, Highlands and Polk Counties, Florida, by Wilder, Michael and Charles D. Frederick, pp. 262-294. Geo-Marine Inc., Plano.

Henderson, J. and G.T. Goode

1991 Pavo Real: An Early Paleoindian site in South-Central Texas. Current Research in the Pleistocene 8:26-28.

Hester, T.R.

1978 Early Human Occupations in South Central and Southwestern Texas: Preliminary Papers on the Baker Cave and St. Mary's Hall Sites. Manuscript on file. Center for Archaeological Research, The University of Texas at San Antonio.

1990 Plainview Artifacts at the St. Mary's Hall Site, South Central Texas. Current Research in the Pleistocene 7:14-17.

1995 The Prehistory of South Texas. Bulletin of the Texas Archeological Society 66:427-459.

Highley, C.L., C. Graves, C. Land, and G. Judson

1978 Archeological Investigations at Scorpion Cave (41ME7) Medina County, Texas. Bulletin of the Texas Archeological Society 49:139-194.

Huebner, J. A.

1991 Late Prehistoric Bison Populations in Central and Southern Texas. Plains Anthropologist 36(137):343-358.

Johnson, L. and G.T. Goode

1994 A New Try at Dating and Characterizing Holocene Climates, as well as Archaeological Periods, on the Eastern Edwards Plateau. Bulletin of the Texas Archaeological Society. Vol. 65: 1-51.

Kalter, A.J., R.M. Rogers and M.N. Smith

2005 Analysis and Reporting for 41FY135, the Sandbur Site, Fayette County, Texas. PBS\&J, Document No. 020388. Archeological Studies Program Report No. 73. Texas Department of Transportation, Austin.

Luchsinger H. and P. Goldberg

2003 Micromorphological Analysis of Sediments at Pavo Real. In Pavo Real (41BX52): A Paleoindian and Archaic Camp and Work-Shop on the Balcones Escarpment, South-Central Texas. by M. B. Collins, D. B. Hudler and S. L. Black, pp. 61-69. Studies in Archeology 41. Texas Archeological Research Laboratory, The University of Texas at Austin.

Martinez, V., S. Dial, P. Buttles, and M.B. Collins

1994 An Assessment of Documents and Collections from the Pavo Real Site (41BX52), Bexar County, Texas. Unpublished Manuscript. Texas Archeological Research Laboratory, The University of Texas at Austin.

Mauldin, R.P., and D.L. Nickels

2001 An Archaeological Survey of Twin Buttes Reservoir, Tom Green County, Texas. Archaeological Survey Report, No. 300. Center for Archaeological Research, The University of Texas at San Antonio.

Mauldin, R.P., D.L. Nickels, and C.J. Broehm

2003 Archaeological Testing to Determine the National Register Eligibility Status of 18 Prehistoric Sites on Camp Bowie, Brown County, Texas (Volume 1 and Volume 2). Archaeological Survey Report No. 334. Center for Archaeological Research, The University of Texas at San Antonio. 
Meltzer, D.J. and M.R. Bever

1995 Paleoindians of Texas: An Update on the Texas Clovis Fluted Point Survey. Bulletin of the Texas Archeological Society 66:47-81.

Nickels, D.L., and R.P. Mauldin

2001 The Project Environment. In An Archaeological Survey of Twin Buttes Reservoir, Tom Green County, Texas, Volume 1, by R. P. Mauldin and D. L. Nickels. Archaeological Survey Report, No. 300. Center for Archaeological Research, The University of Texas at San Antonio.

Nickels, D.L., C.B. Bousman, J.D. Leach, and D.A. Cargill

1998 Test Excavations at the Culebra Creek Site, 41BX126, Bexar County, Texas. Archaeological Survey Report, No. 265. Center for Archaeological Research, The University of Texas at San Antonio.

Patterson, L.W.

1988 Chronology of Arrow Point Types in South Texas. La Tierra 15(4):29-33

Powell, J.F. and D.G. Steele

1994 Diet and Health of Paleoindians: An Examination of Early Holocene Human Dental Remains. In Paleonutrition: The Diet and Health of Prehistoric Americans, edited by Kristen D. Sobolik, pp. 176-92. Occasional Paper No. 22. Carbondale: Center for Archaeological Investigations, Southern Illinois University, Carbondale.

Prewitt, E.R.

1981 Cultural Chronology in Central Texas. Bulletin of the Texas Archaeological Society, 52:65-89.

Quigg, J.M., C. Lintz, F.M. Oglesby, A.C. Earls, C.D. Frederick, W.N. Trierweiler, D. Owsley, and K.W. Kibler 1993 Historic and Prehistoric Data Recovery at Palo Duro Reservoir, Hansford County, Texas. Technical Report 485. Mariah Associates, Inc., Austin.

Ricklis, R.A.

1995 The Ceramics of the Toyah Horizon and the Rockport Phase as Indicators of some Basic Sociocultural Patterns. Bulletin of Texas Archeological Society 66:195-203.

Shennan, S.

1990 Quantifying Archaeology. Edinburgh University Press, Edinburgh.

Skinner, S.A.

1981 Aboriginal Demographic Changes in Central Texas. Plains Anthropologist 26(92):111-118.

South Central Texas Regional Water Planning Group (SCTRWPGP)

http://www.watershedexperience.com/ish_veg_areas.html, Accessed January 15, 2008

Southern Regional Climate Center (SRCC)

http:/www.srcc.lsu.edu/southernClimate/climatesummaries, Accessed January 15, 2008.

Taylor, F.B., R.B. Hailey, and D.L. Richmond

1991 Soil Survey of Bexar County, Texas. U.S. Department of Agriculture Soil Conservation Service. The Soil Conservation Service, Washington, D.C. 
Texas Historical Commission (THC)

Texas Archaeological Sites Atlas. < http://nueces.thc.state.tx.us/>, Accessed January 15, 2008.

Thoms, A.V., D.D. Keuhn, B.W. Olive, J.E. Dockall, P.A. Clabaugh and R.D. Mandel

1996 Early and Middle Holocene Occupations at the Richard Beene Site: The 1995 Southern Texas Archaeological Society Association Field School Project. La Tierra (23) 4:1-36.

Thoms, A.V. and R.D. Mandel

2006 Archaeological and Paleoecological Investigations at the Richard Beene Site 41BX831: South Central Texas. Center for Ecological Archaeology, Reports of Investigations No. 8. Texas A \& M University, College Station.

Toomey, R.S., M.D. Blum, and S. Valastro, Jr.

1993 Late Quaternary Climates and Environments of the Edwards Plateau, Texas. Global and Planetary Change 7:299320.

Turner, E.S. and T.R. Hester 1999 A Field Guide to Stone Artifacts of Texas Indians. $3^{\text {rd }}$ ed. Gulf Publishing Co., Lanham, Maryland.

Waters, M.R.

1992 Principles of Geoarchaeology: A North American Perspective. University of Arizona Press, Tucson.

Winkler, B.A.

1982 Wild Plant Foods of the Desert Gatherers of West Texas, New Mexico and Northern Mexico: Some Nutritional Values. Unpublished Master's thesis, Department of Anthropology, The University of Texas at Austin. 



\section{Appendix}

Quartz Optical Dating Report 


\title{
Sheffield
}

Centre for

International

\section{Quartz Optical Dating Report}

Drylands

Research

$18^{\text {th }}$ June, 2007

Site (41BX52), Texas, USA

\begin{abstract}
Optical luminescence dating at the single grain level was applied to coarse quartz grains extracted from two samples taken from the site 41BX52, Texas. All samples behaved well from an OSL perspective, but analysis of sample replicates indicates they may have undergone some post-depositional disturbance. Best estimates of the sample's burial age range from $18.3 \pm 0.92$ ka (Shfd07129) and $18.2 \pm$ 1.03 ka (Shfd07130).
\end{abstract}

1. Introduction: Two samples in opaque PVC tubing from site 41BX52 San Antonio, Texas, USA were submitted for luminescence dating by Antonia Figueroa (Center for Archaeological Research, UTSA). All luminescence work was carried out at the Sheffield Centre for International Drylands Research (SCIDR) luminescence laboratory. The samples are assumed not to have been exposed to sunlight during sampling or transportation to the laboratory. Upon arrival, each sample was allocated a Sheffield lab number (Table 1). This report provides a brief summary of the procedures employed and results obtained for samples.

Table 1. Sample descriptive data.

\begin{tabular}{cccccc} 
Lab No. & Field Reference & $\begin{array}{c}\text { Latitude } \\
\left(^{\circ} \mathrm{N}\right)\end{array}$ & $\begin{array}{c}\text { Longitude } \\
\text { W) }\end{array}$ & $\begin{array}{c}\left(^{\circ}\right. \\
\text { Altitude } \\
(\mathrm{m})\end{array}$ & $\begin{array}{c}\text { Sampling Depth } \\
(\mathrm{cm} \text { below surface })\end{array}$ \\
Shfd07129 & Sample 1, Block 2, Zone 5 & $29^{\circ} 35^{\prime}$ & $98^{\circ} 36^{\prime}$ & 301 & 1.55 \\
Shfd07130 & Sample 2, Block 2, Zone 6 & $29^{\circ} 35^{\prime}$ & $98^{\circ} 36^{\prime}$ & 301 & 1.35 \\
\hline
\end{tabular}

In order to derive an optically stimulated luminescence (OSL) age both the palaeodose (De - the amount of absorbed dose since the sample was buried) and the dose rate (the estimated radiation flux for the sedimentary bodies) have to be determined. Aitken (1998) gives a detailed explanation of both these parameters. To calculate an age, the palaeodose (expressed in Grays) is divided by the annual dose rate (Grays/yr). An inherent assumption in these age calculations is that the sediment was fully reset or 'bleached' by exposure to sunlight during the last transport event or whilst in situ prior to burial and that no post-depositional sediment disturbance has occurred. As part of this investigation, efforts have been taken to establish if these sediments have been bleached or disturbed by, for example, bioturbation. As the OSL signal measured with a standard aliquot is an average of $\mathbf{2 0 0 0}$ grains the true distribution of De values within a sample may be masked. This is of particular significance in heterogeneously dosed samples (e.g. poorly

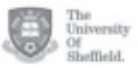

Page 1

SCIDR luminescence laboratory - 18/04/2008

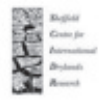


reset/bleached) in which grains with a high De signal will dominated the signal at the expense of grains containing a true burial De. Measurement of the accumulated dose from individual grains obviates this problem. Thus this latter single grain approach was adopted for this study.

2. Dose Rate Analysis: Naturally occurring potassium (K), thorium (Th), rubidium $(R b)$ and uranium $(U)$ are the main contributors of dose to sedimentary quartz. The concentrations of these elements were determined by inductively coupled plasma mass spectrometry (ICP) at SGS laboratories Ontario Canada (Table 2). Elemental concentrations were converted to annual dose rates using data from Adamiec and Aitken (1998), Marsh et al. (2002), and Aitken (1988). This took into account attenuation factors relating to sediment grain sizes used, density and palaeomoisture. It has been assumed that the samples formed part of a thick homogeneous unit with no gamma contribution (other than from cosmogenic sources) being received by the samples from other unsampled sedimentary units. Attenuation of dose by moisture used the present-day moisture values as measured in the laboratory, with $a \pm 2 \%$ error to incorporate seasonal and longer-term fluctuations in moisture which the samples may have endured since burial (Table 2). The contribution to dose rates from cosmic sources were calculated using the expression published in Prescott and Hutton (1994; Table 2). The dose rates calculated are based on analyses of the sediment sampled at the present day. This assumption is only valid if no movement and/or reprecipitation of the four key elements has taken place since sediment burial and the adjacent sediments to those sampled had similar dose rates. Further analysis would have to be undertaken to establish whether the latter is true and if radioactive disequilibrium is present in the dose rate.

Table 2. Summary of results - Dosimetry related data.

\begin{tabular}{|c|c|c|c|c|c|c|c|}
\hline Lab Code & $\underset{(\mathrm{PPM})}{\mathbf{U}}$ & $\begin{array}{c}\text { Th } \\
\text { (PPM) }\end{array}$ & $\begin{array}{c}\mathbf{R b} \\
\text { (PPM) }\end{array}$ & $\begin{array}{c}\mathbf{K} \\
(\%)\end{array}$ & $\begin{array}{l}\mathbf{D}_{\text {cosmic }}+ \\
\left(\mu \mathrm{G} y / \mathrm{a}^{-1}\right)\end{array}$ & Moisture (\%) & $\begin{array}{c}\text { Dose rate } \\
\left(\mu G y / a^{-1}\right)\end{array}$ \\
\hline Shfd07129 & 1.85 & 6.2 & 49.6 & 0.66 & $179 \pm 9$ & 14.0 & $1489 \pm 53$ \\
\hline Shfd07130 & 1.79 & 5.1 & 43.8 & 0.62 & $184 \pm 9$ & 14.0 & $1381 \pm 49$ \\
\hline
\end{tabular}

+ Cosmic dose is calculated as a linear decay curve at depths below $50 \mathrm{~cm}$. Above this depth, errors in calculation may lead to an under-estimation of the cosmic dose contribution.

${ }^{\dagger}$ Total Dose is attenuated for grain size, density and moisture.

3. Palaeodose Determination: The samples were prepared under subdued red lighting following the procedure to extract and clean quartz outlined in Bateman and Catt (1996). Prepared samples were taken from within a maximum size range of $90-250 \mu \mathrm{m}$ to ensure sufficient quartz for measurement. Samples then underwent measurements at the single grain level using a Risø TL DA-15 single grain laser luminescence reader with radiation doses administered using a calibrated ${ }^{90}$ strontium beta source. Grains were mounted in $300 \mu \mathrm{m}$ pits with 100 pits per $9.6 \mathrm{~mm}$ stainless steel aliquot. A focussed $532 \mathrm{~nm} \mathrm{Nd:YVO}{ }_{4}$ laser provided

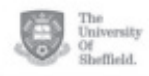

Page 2

SCIDR luminescence laboratory - 18/04/2008

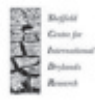


the stimulation and luminescence detection was through a Hoya U-340 filter. All samples were analysed using the single aliquot regenerative (SAR) approach (Murray and Wintle 2000), in which an interpolative growth curve is constructed using data derived from repeated measurements of a single aliquot which has been given various laboratory irradiations (Figure 1). The last irradiation dose replicated the first to check if sensitivity changes cause by repeated measurement of the same aliquot had been correctly monitored and corrected for by the SAR protocol ((known as the recycling ratio)

(a)

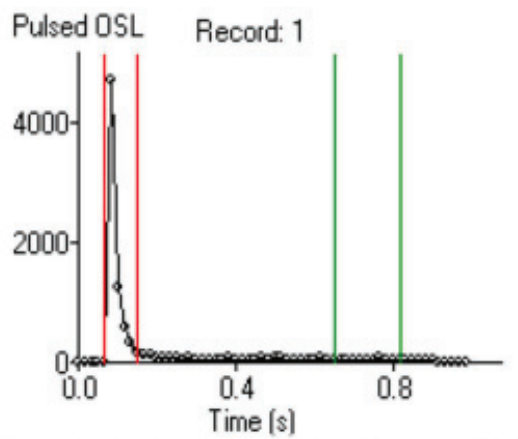

(b)

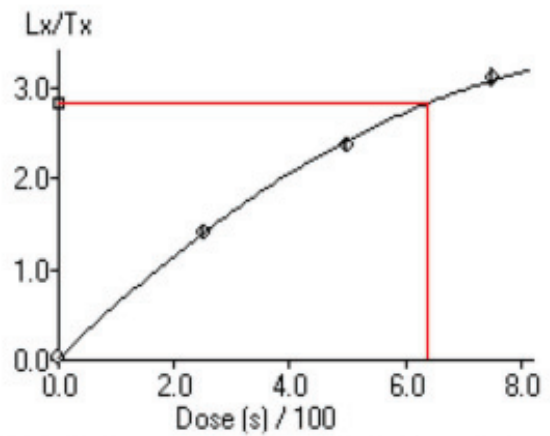

Figure 1: Examples of single grain OSL data for sample Shfd07129 (a) OSL decay of naturally acquired signal showing a strong OSL signal and rapid decay and (b) a SAR growth curve showing good increase in OSL with increasing laboratory doses.

Within the SAR protocol a preheat of $240^{\circ} \mathrm{C}$ for 10 seconds prior to OSL measurement was used to remove unstable signal generated by laboratory irradiations. This preheat was derived experimentally using a dose recovery test with a range of preheat temperatures (after Murray and Wintle, 2003). As Figure 2 shows the $240^{\circ} \mathrm{C}$ for 10 preheat recovers the 40 s exposure to the laboratory beta radiation source within errors and has recycling ratios within $\pm 10 \%$.

(a)

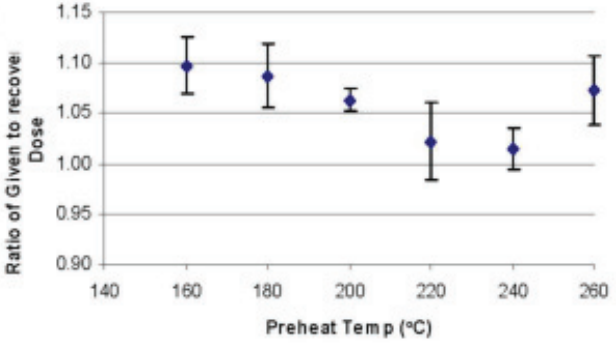

(b)

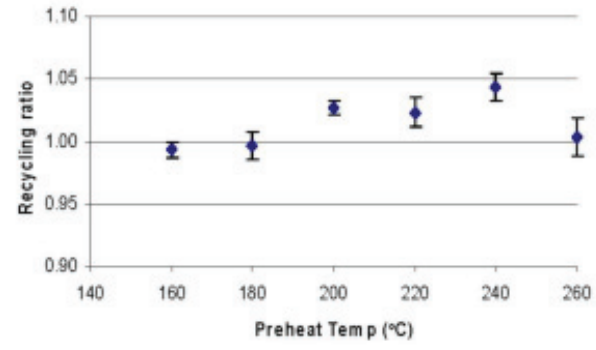

Figure 2. Results of Dose recovery test on Shfd07129 used to determine appropriate preheat for SAR protocol. (a) Results of different preheat recovering a $40 \mathrm{~s}$ exposure to the laboratory beta radiation source; (b) recycling ratio of different preheats.

With all single grain OSL analysis many grains exhibit insufficient OSL signal to be utilised and/or are too poorly behaved for the De to be accurately measured. De values from individual grains were only accepted where their recycling ratio was $1 \pm 0.20$, they exhibited good growth with dose and the error on the test dose used within the SAR protocol was less than 20\%. As Table 3 shows, for sample Shfd07129 200 grains were measured of which $43 \%$ yielded grains which met these criteria. For sample Shfd 07130 of the

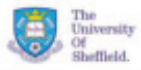

Page 3

SCIDR luminescence laboratory - 18/04/2008

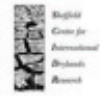


300 grains measured $31.5 \%$ yielded grains which met these criteria. These return rates are very high compared to other sites within Texas and further a field (typically $<10 \%$ of grains yield usable data) indicating that the quartz grains from 41BX52 are behaving as good natural dosimeters with relatively high sensitivity to dose.

4. Sedimentary bleaching behaviour: The effects of incomplete bleaching of the sediment during the last period of transport or exposure in situ can be profound. Typically, poorly bleached sediments retain a significant level of residual signal from previous phases of sedimentary cycling, leading to inherent inaccuracies in the calculation of a palaeodose value. By plotting the replicate data for each sample as a probability density function some assessment of whether older or younger material has been included in the sample measurements can be made (Figure 3). In principle a well bleached unpost-depositionally disturbed sample should have replicate palaeodose (De) data which is normally distributed and highly reproducible (See Bateman et al. 2003, Fig 3; Bateman et al 2007a). Where post-depositional disturbance or incomplete bleaching prior to sample burial has occurred skewing of this distribution may occur and/or replicate reproducibility may be lower (Bateman et al 2007a; Bateman et al. 2007b). In the case of poorly bleached material skewing should be evident with a high De tail (e.g. Olley et al. 2004).

As Figure 3 (and appendix 1) shows the single grain data distributions are similar. For both samples the De distributions are unskewed but much broader than would be expected for a well-bleached undisturbed sediment with OD values in excess of $30 \%$ (Table 3; Bateman et al. 2007a). It has been argued that where significant numbers of zero dose grains have been measured this is indicative of grains which have recently been exhumed and returned to depth by, for example, bioturbation (see Heimsath 2002; Bateman et al 2007b). This is not the case for these samples. Thus if the broadness of the De distributions is due to some bioturbation it has occurred subsurface and reflects a limited amount of grain movement both up and down. It is recommended that other information about the depositional style of the sediments, site stratigraphy and sedimentological/archaeological evidence are examined to support or refute this data interpretation.

Table 3. Summary of single grain OSL De results including their over-dispersion values (OD; Galbraith et al. 1999) and a description and interpretation of the De replicate distributions. Zero grains are assumed to indicate recent exhumation to the surface of grains and burial whereas skewing and high De outliers are assumed to indicate internal mixing upward of older grains.

\begin{tabular}{ccccccc}
\hline Lab Code & $\begin{array}{c}\text { Total N } \\
\text { Grains } \\
\text { Measured }\end{array}$ & $\begin{array}{c}\text { Usable } \\
\text { Grains }\end{array}$ & $\begin{array}{c}\text { Zero } \\
\text { Grain }^{\ddagger} \\
(\%)\end{array}$ & $\begin{array}{c}\text { OD } \\
(\%)\end{array}$ & De Distribution & Interpretation \\
\hline Shfd07129 & 300 & $31 \%$ & 0 & 31.5 & Normal but broad with extended tails & Possibly bioturbated (internal mixing) \\
Shfd07130 & 200 & $43 \%$ & 0 & 38.6 & Normal but broad with extended tails & Possibly bioturbated (internal mixing) \\
\hline
\end{tabular}

\footnotetext{
${ }^{\ddagger}$ Zero dose grains counted as those with a De $<0.2 \mathrm{~Gy}$, error not taken into account.
}

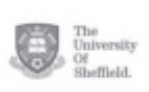

Page 4

SCIDR luminescence laboratory - 18/04/2008

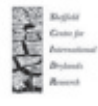



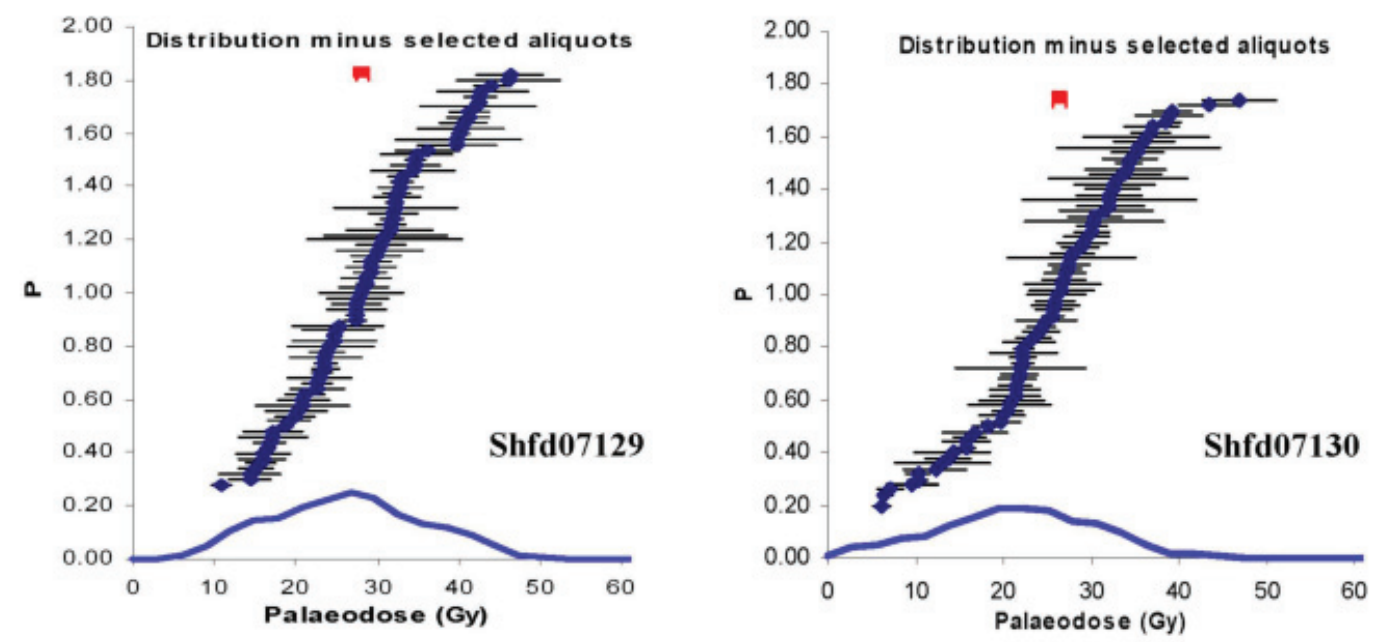

Figure 3: Combined probability density functions for the single grains results showing degree of inter-grain reproducibility. Also plotted are individual grain De (black) and the unweighted mean De (red).

Table 4. Final Ages based on dominant De component as calculated using the Central Age Model (Galbraith and Green 1990).

\begin{tabular}{|c|c|c|c|c|}
\hline Lab Code & Field Ref. & Depth $\quad(\mathrm{cm})$ & $\begin{array}{c}\text { Single Grain De } \\
\text { (Gy) }\end{array}$ & $\begin{array}{l}\text { Single Grain Age } \\
\text { (ka) }\end{array}$ \\
\hline Shfd07129 & Sample 1, Block 2, Zone 5 & 155 & $27.18 \pm 0.97$ & $18.3 \pm 0.92$ \\
\hline Shfd07130 & Sample 2, Block 2, Zone 6 & 135 & $25.13 \pm 1.11$ & $18.2 \pm 1.03$ \\
\hline
\end{tabular}

5. Age Calculation and Conclusions: Ages are quoted in years from the present day (2007) and are presented with one sigma confidence intervals which incorporate systematic uncertainties with the dosimetry data, uncertainties with the palaeomoisture content and errors associated with the De determination. Table 4 shows the ages calculated. As can be seen from this sample Shfd07129 returns an age of $18.3 \pm 0.92 \mathrm{ka}$ and sample Shfd07130 an age of $18.2 \pm 1.03 \mathrm{k}$. As the samples are both within errors of each other these ages are indistinguishable suggesting a relatively short temporal gap between deposition of Zone 6 and Zone 5 at block 2 of the $41 B \times 52$ site. 


\section{References:}

ADAMIEC G. and AITKEN MJ. (1998). Dose-rate conversion factors update. Ancient TL 16: 37-50

AITKEN, M. J. (1998). An Introduction to Optical Dating: The dating of Quatemary sediments by the use of Photo-Stimulated Luminescence. Oxford Science Publication.

BATEMAN, M.D., BOULTER, C.H., CARR, A.S., FREDERICK, C.D., PETER, D., WILDER, M. (2007a). Detecting Post-depositional sediment disturbance in sandy deposits using optical luminescence. Quaternary Geochronology 2, 57-64.

BATEMAN, M.D., BOULTER, C.H., CARR, A.S., FREDERICK, C.D., PETER, D. AND WILDER, M. (2007b). Preserving the palaeoenvironmental record in Drylands: Bioturbation and its significance for luminescence derived chronologies. Sediment Geology, 195, 5-19.

BATEMAN, M.D. FREDERICK, C.D., JAISWAL, M.K. AND SINGHVI, A.K. (2003). Investigations into the potential effects of pedoturbation on luminescence dating. Quaternary Science Reviews, 22, 1169-1176.

BATEMAN, M.D. \& CATT, J.A. (1996). An absolute chronology for the raised beach deposits at Sewerby, E. Yorkshire, UK. Journal of Quaternary Science, 11, 389-395.

GALBRAITH, R.F. and GREEN, P.F. (1990). Estimating the component ages in a finite mixture. Radiation Measurements, 17,197-206.

GALBRAITH, R.F, ROBERTS, R.G., LASLETT, G.M., YOSHIDA, H., OLLEY, J.M. (1999). Optical dating of single and multiple grains of quartz from Jinmium Rock shelter, northern Australia. Part I, experimental design and statistical models. Archaeometry, 41, 339-364.

HEIMSATH, A.M., CHAPPELL, J., SPOONER, N.A. AND QUESTIAUX, D.G. (2002). Creeping Soil. Geological Society of America, 30, 111-114.

MARSH RE, PRESTWICH WV, RINK WJ, BRENNAN BJ. (2002). Monte Carlo determinations of the beta dose rate to tooth enamel. Radiation Measurements 35: 609-616

MURRAY, A.S. \& WINTLE, A.G. (2000). Luminescence dating of quartz using an improved single-aliquot regenerative-dose protocol. Radiation Measurements 32, 57-73.

MURRAY AS, WINTLE AG. (2003). The single aliquot regenerative dose protocol: potential for improvements in reliability. Radiation Measurements 37: 377-381.

OLLEY, J.M., PIETSCH T., ROBERTS, R.G. (2004). Optical dating of Holocene sediments from a variety of geomorphic settings using single grains of quartz. Geomorphology 60, 337-358.

PRESCOTT, J.R. \& HUTTON, J.T. (1994). Cosmic ray contributions to dose rates for luminescence and ESR dating: large depths and long-term time variations. Radiation Measurements, 2/3, 497-500.

Dr Mark D. Bateman

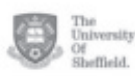

Page 6

SCIDR luminescence laboratory - 18/04/2008

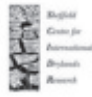




\section{Appendix 1}

\section{Single grain data and plots for site 41BX52, Texas, USA.}

Sample specific data:-

- Individual grain De replicate data

- Histogram of De replicate data

- $\quad$ probability density plot (curve) with ranked single grain De data and probability mean (uppermost point).

- Radial plot of De replicate data 
Field Code:

Lab Code:

Single Grain Replicate Data

$\begin{array}{rcc}\text { Grain } & \text { Palaeodose (Gy) } & \text { error } \\ 1 & 30.89 & 9.40 \\ 2 & 34.67 & 1.32 \\ 3 & 42.62 & 2.07 \\ 4 & 16.55 & 0.72 \\ 5 & 44.16 & 2.22 \\ 6 & 32.47 & 1.62 \\ 7 & 40.33 & 5.28 \\ 8 & 30.98 & 7.53 \\ 9 & 22.48 & 3.30 \\ 10 & 23.83 & 2.11 \\ 11 & 19.16 & 2.47 \\ 12 & 28.51 & 1.08 \\ 13 & 25.18 & 5.60 \\ 14 & 30.26 & 5.37 \\ 15 & 15.87 & 2.88 \\ 16 & 27.34 & 1.04 \\ 17 & 32.37 & 2.86 \\ 18 & 27.38 & 3.64 \\ 19 & 18.75 & 0.94 \\ 20 & 24.82 & 0.83 \\ 21 & 52.34 & 3.33 \\ 22 & 14.43 & 3.78 \\ 23 & 32.19 & 7.62 \\ 24 & 16.01 & 3.40 \\ 25 & 21.09 & 2.50 \\ 26 & 27.61 & 3.89 \\ 27 & 31.70 & 1.75 \\ 28 & 28.33 & 3.10 \\ 29 & 41.23 & 2.54 \\ 30 & 23.65 & 1.35 \\ 31 & 33.23 & 1.84 \\ 32 & 40.15 & 1.10 \\ 33 & 31.88 & 1.37 \\ 34 & 32.96 & 1.42 \\ 35 & 39.79 & 4.74 \\ 36 & 19.78 & 2.38 \\ 37 & 25.09 & 4.36 \\ 38 & 31.52 & 5.42 \\ 39 & 32.87 & 2.81 \\ 40 & 39.93 & 7.62\end{array}$

OSL \#1

Shfd07129
62

5.28

30

.11

.47

60

.37

04

86

.94

3.33

.40

3.89

.75

54

1.84

.42

74

36

42

7.62
Site: $41 B X 52$

San Antonio, Tx

\begin{tabular}{|c|c|c|}
\hline Grain & Palaeodose (Gy) & error \\
\hline 41 & 27.29 & 1.24 \\
\hline 42 & 2.61 & 0.88 \\
\hline 43 & 24.14 & 5.28 \\
\hline 44 & 23.60 & 1.68 \\
\hline 45 & 17.13 & 4.16 \\
\hline 46 & 14.39 & 2.56 \\
\hline 47 & 46.13 & 6.25 \\
\hline 48 & 30.53 & 3.06 \\
\hline 49 & 34.85 & 4.36 \\
\hline 50 & 32.19 & 1.08 \\
\hline 51 & 20.91 & 3.12 \\
\hline 52 & 20.82 & 5.71 \\
\hline 53 & 24.64 & 5.13 \\
\hline 54 & 42.90 & 5.55 \\
\hline 55 & 34.62 & 2.92 \\
\hline 56 & 15.15 & 2.07 \\
\hline 57 & 42.26 & 7.13 \\
\hline 58 & 29.14 & 1.89 \\
\hline 59 & 17.18 & 3.48 \\
\hline 60 & 28.60 & 3.01 \\
\hline 61 & 29.36 & 2.29 \\
\hline 62 & 23.65 & 4.45 \\
\hline 63 & 29.90 & 3.10 \\
\hline 64 & 28.15 & 5.10 \\
\hline 65 & 16.77 & 2.07 \\
\hline 66 & 10.75 & 1.24 \\
\hline 67 & 36.15 & 3.96 \\
\hline 68 & 22.88 & 3.98 \\
\hline 69 & 15.69 & 1.68 \\
\hline 70 & 41.41 & 2.38 \\
\hline 71 & 29.18 & 3.06 \\
\hline 72 & 40.56 & 2.88 \\
\hline 73 & 34.39 & 5.24 \\
\hline 74 & 42.44 & 0.86 \\
\hline 75 & 23.20 & 1.17 \\
\hline 76 & 31.88 & 3.01 \\
\hline 77 & 27.52 & 3.04 \\
\hline 78 & 22.57 & 1.82 \\
\hline 79 & 46.40 & 4.09 \\
\hline 80 & 20.06 & 3.87 \\
\hline
\end{tabular}

1.24

5.28

1.68

4.16

6.25

3.06

1.08

3.12

5.71

55

92

1.89

.29

4.45

5.10

2.07

1.24

3.98

.06

.88

1.17

3.01

1.82

3.87 $\begin{array}{lr}\text { Min De (Gy) } & 2.61 \\ \text { Max De (Gy) } & 52.34\end{array}$ 
Field Code:

Lab Code:

Average Replicate Data

Unweighted

Mean (Gy)

SD

SE

n

Central age model Mean

SE

Overdispersion

$\mathrm{N}$

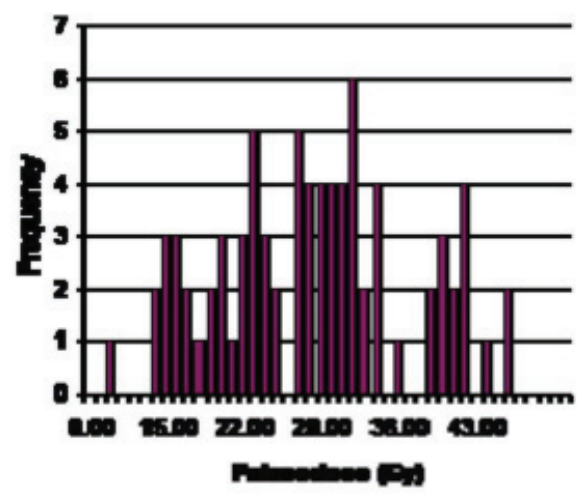

OSL \#1

Shfd07129
28.608

8.661

0.981

78

27.18

0.97

$31.5 \%$

92
Site: $\quad 41 B \times 52$

San Antonio, Tx

$\begin{array}{lrl}\begin{array}{c}\text { Weighte } \\ \text { d }\end{array} & & \text { Probability } \\ \begin{array}{l}\text { Mean } \\ \text { (Gy) }\end{array} & 27.24 & \\ \text { SD } & 4 & \text { Mean (Gy) } \\ \text { SE } & 8.727 & \text { SD } \\ & 0.988 & \text { SE }\end{array}$

28.154

7.179

0.813

\section{Common age model}

$\begin{array}{lr}\text { Mean } & 30.30 \\ \text { SE } & 0.21\end{array}$
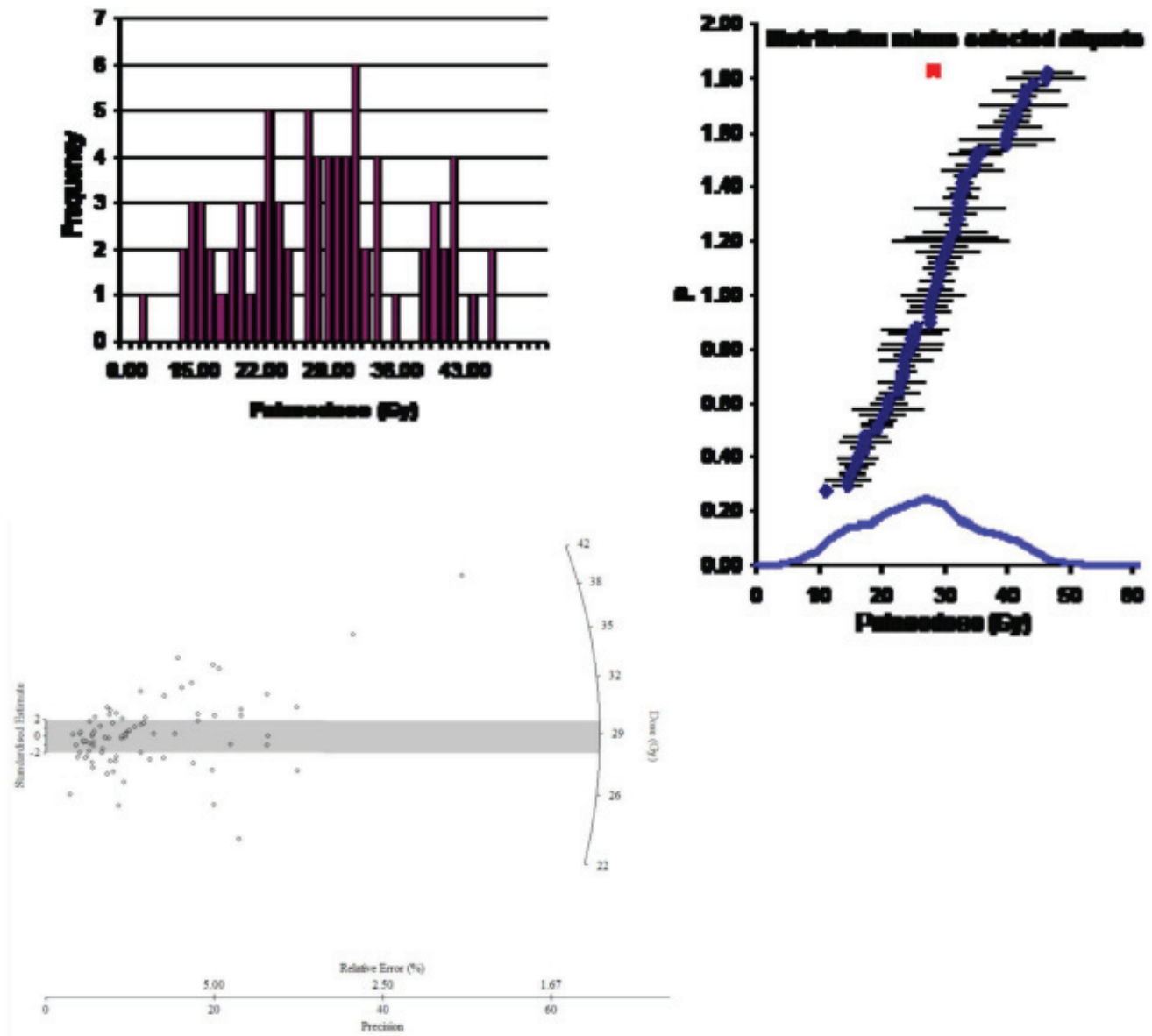

Page?

SCIDR luminescence laboratory - 18/04/2008

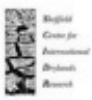


Field Code:

Lab Code:

Single Grain Replicate Data
OSL \#2

Shfd07130
Site: 41BX52

San Antonio, Tx

\begin{tabular}{|c|c|c|}
\hline Grain & Palaeodose (Gy) & errol \\
\hline 1 & 46.87 & 4.17 \\
\hline 2 & 39.21 & 2.27 \\
\hline 3 & 19.92 & 2.6 \\
\hline 4 & 27.32 & 1.6 \\
\hline 5 & 25.94 & 2.2 \\
\hline 6 & 34.22 & $1.4 \xi$ \\
\hline 7 & 33.01 & 7.87 \\
\hline 8 & 29.05 & 2.86 \\
\hline 9 & 65.87 & 18. \\
\hline 10 & 34.49 & 3.0 \\
\hline 11 & 32.15 & 3.8 \\
\hline 12 & 47.57 & 9.1 \\
\hline 13 & 16.19 & 1.96 \\
\hline 14 & 28.78 & 2.0 \\
\hline 15 & 22.21 & 1.28 \\
\hline 16 & 30.39 & 3.1 \\
\hline 17 & 32.15 & 9.9 \\
\hline 18 & 22.35 & 1.12 \\
\hline 19 & 9.62 & 3.0 \\
\hline 20 & 16.82 & 3.6 \\
\hline 21 & 19.74 & 2.2 \\
\hline 22 & 21.94 & 2.1 \\
\hline 23 & 24.32 & 1.6 \\
\hline 24 & 6.11 & 0.9 \\
\hline 25 & 14.25 & 4.3 \\
\hline 26 & 26.08 & 3.3 \\
\hline 27 & 30.17 & 2.0 \\
\hline 28 & 21.40 & 1.8 \\
\hline 29 & 24.24 & 2.0 \\
\hline 30 & 20.68 & 4.6 \\
\hline 31 & 26.89 & 2.3 \\
\hline 32 & 37.01 & 3.0 \\
\hline 33 & 29.54 & 2.5 \\
\hline 34 & 13.13 & 5.3 \\
\hline 35 & 21.36 & 2.8 \\
\hline 36 & 31.70 & 5.3 \\
\hline 37 & 32.55 & 3.0 \\
\hline 38 & 38.44 & 1.8 \\
\hline 39 & 30.17 & 1.7 \\
\hline 40 & 23.52 & 2. \\
\hline
\end{tabular}

Min De (Gy)

$\operatorname{Max} \operatorname{De}(\mathrm{Gy})$
65.87

\begin{tabular}{|c|c|c|}
\hline Grain & Palaeodose (Gy) & error \\
\hline 41 & 10.30 & 1.08 \\
\hline 42 & 12.23 & 3.60 \\
\hline 43 & 22.30 & 3.76 \\
\hline 44 & 22.26 & 1.55 \\
\hline 45 & 36.78 & 2.32 \\
\hline 46 & 21.94 & 7.37 \\
\hline 47 & 32.65 & 4.54 \\
\hline 48 & 47.39 & 3.42 \\
\hline 49 & 35.97 & 3.48 \\
\hline 50 & 25.76 & 2.16 \\
\hline 51 & 10.30 & 1.35 \\
\hline 52 & 33.99 & 4.54 \\
\hline 53 & 35.39 & 9.29 \\
\hline 54 & 38.98 & 3.84 \\
\hline 55 & 26.75 & 4.36 \\
\hline 56 & 21.63 & 2.18 \\
\hline 57 & 27.74 & 7.24 \\
\hline 58 & 25.67 & 1.22 \\
\hline 59 & 18.30 & 1.80 \\
\hline 60 & 22.98 & 2.94 \\
\hline 61 & 27.52 & 2.29 \\
\hline 62 & 13.71 & 2.54 \\
\hline 63 & 27.92 & 2.56 \\
\hline 64 & 25.81 & 2.72 \\
\hline 65 & 32.15 & 3.71 \\
\hline 66 & 25.00 & 3.51 \\
\hline 67 & 27.07 & 2.27 \\
\hline 68 & 26.71 & 3.66 \\
\hline 69 & 36.29 & 7.06 \\
\hline 70 & 21.04 & 3.69 \\
\hline 71 & 20.42 & 1.71 \\
\hline 72 & 6.52 & 0.88 \\
\hline 73 & 35.34 & 2.97 \\
\hline 74 & 15.78 & 1.12 \\
\hline 75 & 15.83 & 2.78 \\
\hline 76 & 43.48 & 3.55 \\
\hline 77 & 21.36 & 2.88 \\
\hline 78 & 7.15 & 1.48 \\
\hline 79 & 33.95 & 3.98 \\
\hline 80 & 30.31 & 7.89 \\
\hline
\end{tabular}

Page 10

SCIDR luminescence laboratory - 18/04/2008

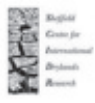


Field Code:

Lab Code:

OSL \#2

Shfd07130
Site: $41 B \times 52$

San Antonio, Tx

Averaged Replicate Data

Unweighted

Mean (Gy)

SD

SE

$\mathrm{n}$

Central age model

Mean (Gy)

SE

Overdispersion

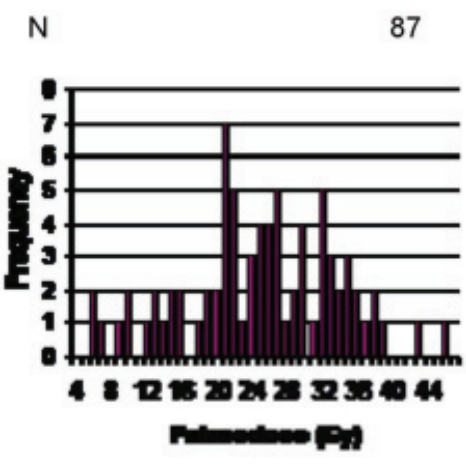

$38.6 \%$
Weighte

$\begin{array}{crl}\begin{array}{c}\text { d } \\ \text { Mean }\end{array} & 20.89 & \text { Probability } \\ \text { (Gy) } & 8 & \text { Mean (Gy) } \\ \text { SD } & 9.552 & \text { SD } \\ \text { SE } & 1.089 & \text { SE }\end{array}$

6.545

0.746

Common age model

Mean

$25.13 \quad$ (Gy) 27.39

$\begin{array}{lll}1.11 & \mathrm{SE} & 0.27\end{array}$
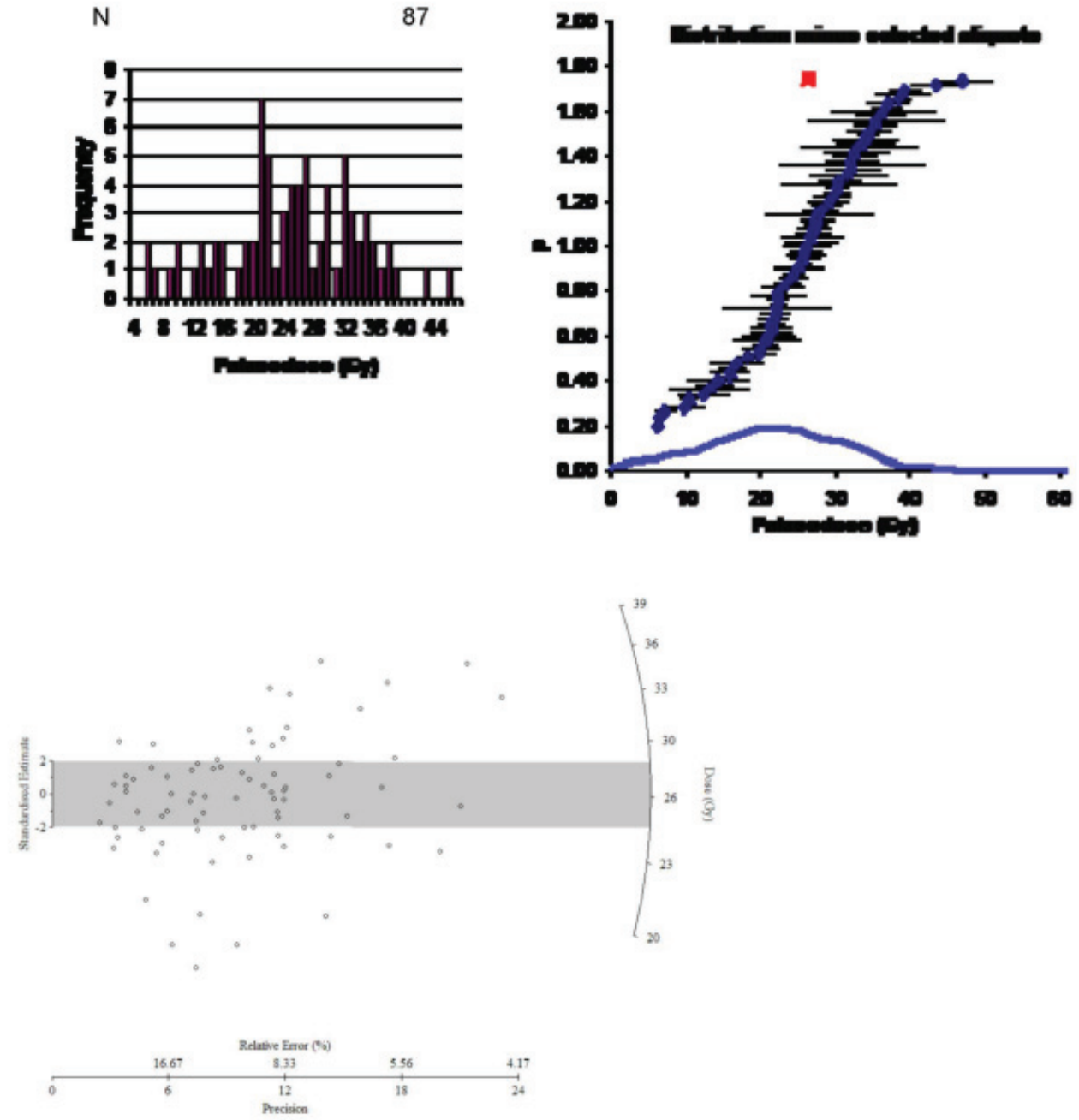

Page 11 